University of California, Hastings College of the Law

UC Hastings Scholarship Repository

Faculty Scholarship

2020

\title{
Providing Adolescents with Independent and Confidential Access to Childhood Vaccines: A Proposal to Lower the Age of Consent
}

Lois A. Weithorn

UC Hastings College of the Law, weithorn@uchastings.edu

Dorit R. Reiss

UC Hastings College of the Law, reissd@uchastings.edu

Follow this and additional works at: https://repository.uchastings.edu/faculty_scholarship

\section{Recommended Citation}

Lois A. Weithorn and Dorit R. Reiss, Providing Adolescents with Independent and Confidential Access to Childhood Vaccines: A Proposal to Lower the Age of Consent, 52 Conn. L. Rev. 771 (2020).

Available at: https://repository.uchastings.edu/faculty_scholarship/1812

This Article is brought to you for free and open access by UC Hastings Scholarship Repository. It has been accepted for inclusion in Faculty Scholarship by an authorized administrator of UC Hastings Scholarship Repository. For more information, please contact wangangela@uchastings.edu. 


\title{
CONNECTICUT \\ LAW REVIEW
}

\begin{tabular}{lll}
\hline \hline VOLUME 52 & JULY 2020 & NUMBER 2 \\
\hline \hline
\end{tabular}

\begin{abstract}
Article
Providing Adolescents with Independent and Confidential Access to Childhood Vaccines: A Proposal to Lower the Age of Consent
\end{abstract}

\section{LOIS A. WEITHORN \& DORIT RUBINSTEIN REISS}

The recent rise in rates of nonvaccination and vaccine-preventable diseases and the attendant risks to the public's health require that lawmakers consider new policy solutions. This Article proposes one such solution. We recommend creation of a limited exception to parental decisionmaking authority by permitting certain older minors to provide legally binding consent for childhood vaccinations and protecting the confidentiality of minors who request vaccination. We analogize this proposed policy to other statutory exceptions that permit certain minors independent access to services relating to contraception, pregnancy, sexually transmitted diseases, mental health and substance abuse, and sexual assault. In this interdisciplinary paper, we analyze the constitutional, policy, scientific, and practical issues relevant to this proposal, and provide lawmakers with a blueprint with which to enact the proposed legislative reform. We also suggest that, in the absence of legislative action, courts allow mature minors to consent independently to recommended childhood vaccinations. 
Article Contents

INTRODUCTION. .773

I. VACCINES, THE ANTI-VACCINE MOVEMENT, AND THE VACCINATION CRISIS .779

A. ReCOMMENDED VACCINES' RISKS AND BENEFITS ..........................779

B. Why DON'T PARENTS VACCINATE? ………................................ 785

II. AUTHORITY FOR HEALTH CARE DECISIONS FOR MINORS: THE LEGAL LANDSCAPE 789

A. The Doctrine of PARENTAL ConSEnT …….................................... 789

B. EXCEPTIONS TO THE DOCTRINE OF PARENTAL CONSENT ................ 796

III. INDEPENDENT AND CONFIDENTIAL ACCESS BY ADOLESCENTS TO CHILDHOOD VACCINES: MEDICAL, LEGAL, PSYCHOLOGICAL, AND POLICY ISSUES 829

A. The Necessity of An Exception to the Doctrine of PARental CONSENT 829

B. STATUTORY AUTHORIZATION OF ADOLESCENTS' INDEPENDENT CONSENT FOR CHILDHOOD VACCINATIONS 835

C. PROTECTING THE CONFIDENTIALITY OF MiNORS' INDEPENDENT CONTACTS With HEalth Care Professionals Regarding VACCINATIONS

IV. STATES LEGISLATION AUTHORIZING MINORS' CONSENT TO VACCINATION: A PROPOSAL 850

V. JUDICIAL CREATION OF A TREATMENT-SPECIFIC MATURE MINOR RULE AUTHORIZING CAPABLE MINORS TO CONSENT TO VACCINES IN THE ABSENCE OF PERTINENT STATE LEGISLATION 857

CONCLUSION 859

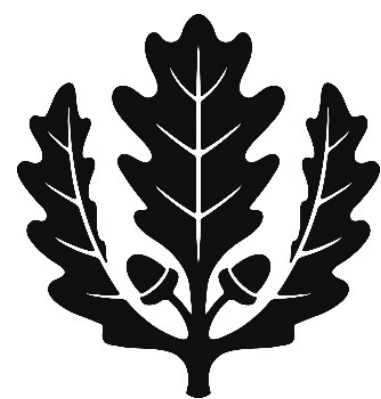




\title{
Providing Adolescents with Independent and Confidential Access to Childhood Vaccines: A Proposal to Lower the Age of Consent
}

\author{
LOIS A. WEITHORN \& DORIT RUBINSTEIN REISS * \\ INTRODUCTION
}

The World Health Organization identified vaccine hesitancy (that is, an individual's lack of confidence in vaccines, often leading to vaccine refusal) ${ }^{1}$ as one of the major threats to global health in $2019 .^{2}$ Vaccine hesitancy is an important contributor of recent upsurges in rates of infection from diseases such as measles and pertussis. ${ }^{3}$ In the first six months of 2019, 1095 cases of measles were confirmed across twenty-eight states in the United States. ${ }^{4}$ According to the Centers for Disease Control and Prevention (CDC), "[ $\mathrm{t}] \mathrm{his}$ is the greatest number of cases reported in the U.S. since 1992" and since the elimination of measles in $2000 .^{5}$ The number of pertussis cases reported annually in the last ten years has reached levels that had "not been observed in more than 5 decades."

In the last several years, researchers have demonstrated the strong relationship between parental refusal to immunize their children and higher rates of infection with vaccine-preventable diseases. ${ }^{7}$ Researchers have also

* Lois A. Weithorn, J.D., Ph.D.; Professor of Law, Harry \& Lillian Hastings Research Chair, University of California-Hastings College of Law. Dorit Rubinstein Reiss, LLB, Ph.D.; Professor of Law, James Edgar Hervey Chair in Litigation, University of California-Hastings College of Law. The authors gratefully acknowledge the enormously helpful feedback on earlier versions of this manuscript provided by Dr. Paul Offit, Dr. Douglas Opel, and Professor Michael Wald. We also thank Arianna Brady, Margot Brooks, Kya Coletta, Allyson Cox, Enne-Mae Guttiarez, and Alexandra (Ally) Relat for excellent research assistance.

${ }^{1}$ Eve Dubé et al., Vaccine Hesitancy: An Overview, 9 Hum. VACCINES \& IMMUNOTHERAPEUTICS 1763,1763 (2013).

2 Ten Threats to Global Health in 2019, WORLD HEALTH ORG., https://www.who.int/emergencies/ten-threats-to-global-health-in-2019 (last visited Oct. 15, 2019).

${ }^{3}$ Varun K. Phadke et al., Association Between Vaccine Refusal and Vaccine-Preventable Diseases in the United States: A Review of Measles and Pertussis, 315 JAMA 1149, 1150 (2016).

4 Measles Cases and Outbreaks, Centers fOr DiseAse CONTROL \& Prevention, https://www.cdc.gov/measles/cases-outbreaks.html (last visited July 3, 2019).

${ }^{5} \mathrm{Id}$.

${ }^{6}$ Phadke et al., supra note 3, at 1153.

${ }^{7}$ For reviews of the literature, see Phadke et al., supra note 3, at 1150; Dorit Rubinstein Reiss \& Lois A. Weithorn, Responding to the Childhood Vaccination Crisis: Legal Frameworks and Tools in the Context of Parental Vaccine Refusal, 63 BufF. L. REv. 881, 930-31 (2015) [hereinafter Reiss \& Weithorn, Responding to the Childhood Vaccination Crisis]; Lois A. Weithorn \& Dorit Rubinstein Reiss, 
demonstrated that legal policies governing exemptions from states' school-entry vaccination requirements affect rates and patterns of intentional nonvaccination in the United States. ${ }^{8}$ In response to these data, lawmakers in several states have tightened exemption policies. ${ }^{9}$ Such reforms are critical to protecting the public's health from the dangers posed by vaccine refusal. Yet the scope of the childhood vaccination crisis and the recalcitrance exhibited by many parents who reject vaccines necessitate additional legal reforms. We recommend providing older minors with the legal authority to consent to vaccinations independent of their parents as one such reform.

On June 10, 2019, at the annual meeting of the American Medical Association (AMA), the Association's delegates voted "to support 'state

Legal Approaches to Promoting Parental Compliance with Childhood Immunization Recommendations, 14 HUM. VACCINES \& IMMUNOTHERAPEUTICS 1610, 1610-11 (2018).

${ }^{8}$ See, e.g., Nina R. Blank et al., Exempting Schoolchildren from Immunizations: States with Few Barriers Had Highest Rates of Nonmedical Exemptions, 32 HEALTH AFF. 1282, 1289 (2013) (finding that non-vaccination rates in states with simpler nonmedical exemption procedures and less stringent requirements were more than twice as high as those in states with more-complex procedures and more stringent requirements); Daniel R. Feikin et al., Individual and Community Risks of Measles and Pertussis Associated with Personal Exemptions to Immunization, 284 JAMA 3145, 3145 (2000) (reviewing studies demonstrating dramatically elevated measles risk in unvaccinated children exempted from vaccination mandates); Aamer Imdad et al., Religious Exemptions for Immunization and Risk of Pertussis in New York State, 2000-2011, 132 PEDIATRICs 37, 42 (2013) (finding higher rates of pertussis in New York State counties with higher rates of vaccine exemptions); Saad B. Omer et al., Nonmedical Exemptions to School Immunization Requirements: Secular Trends and Association of State Policies with Pertussis Incidence, 296 JAMA 1757, 1763 (2006) (finding elevated exemption rates and pertussis incidence in jurisdictions that permit personal belief exemptions and are lenient in granting exemptions); Saad B. Omer et al., Vaccination Policies and Rates of Exemption from Immunization, 2005-2011, 367 NEW ENG. J. MED. 1170, 1171 (2012) (analyzing the relationship between legal exemption policies and rates of exemption); Jennifer L. Richards et al., Nonmedical Exemptions to Immunization Requirements in California: A 16-Year Longitudinal Analysis of Trends and Associated Community Factors, 31 VACCINE 3009, 3012 (2013); Daniel A. Salmon et al., Factors Associated with Refusal of Childhood Vaccines Among Parents of School-aged Children, 159 ARCHIVES PEDIATRICS \& ADOLESCENT MED. 470, 470 (2005) (demonstrating higher rates of disease in areas with higher exemption rates); Daniel A. Salmon et al., Health Consequences of Religious and Philosophical Exemptions from Immunization Laws: Individual and Societal Risk of Measles, 281 JAMA 47, 51 (1999) (demonstrating statistical relationship between increasing rates of exemption and increases in outbreaks of vaccine-preventable diseases); Stephanie Stadlin et al., Medical Exemptions to School Immunization Requirements in the United States-Association of State Policies with Medical Exemption Rates (2004-2011), 206 J. INFECTIOUS DISEASES 989, 989 (2012) (demonstrating relationship between ease of obtaining medical exemptions in states and rates of medical exemptions); Joseph W. Thompson et al., Impact of Addition of Philosophical Exemptions on Childhood Immunization Rates, 32 AM. J. PREVENTIVE MED. 194, 200 (2007) (demonstrating relationship between availability of philosophical exemptions in Arkansas and geographic risk of disease outbreaks); Y. Tony Yang \& Vicky Debold, A Longitudinal Analysis of the Effect of Nonmedical Exemption Law and Vaccine Uptake on Vaccine-Targeted Disease Rates, 104 AM. J. PUB. HEALTH 371, 375-76 (2014) (analyzing relationships between exemption policies, vaccination rates, and rates of infection).

${ }^{9}$ For recent legislative changes in vaccine exemption laws, see States with Religious and Philosophical Exemptions from School Immunization Requirements, NAT'L CONF. ST. LEGISLATURES (June 14, 2019), http://www.ncsl.org/research/health/school-immunization-exemption-state-laws.aspx. 
policies allowing minors to override their parent's refusal for vaccinations' and encourage 'state legislatures to establish comprehensive vaccine and minor consent policies." "10 Five days before the AMA action, Professors Ross Silverman, Douglas Opel, and Saad Omer published an article in the New England Journal of Medicine suggesting that state laws be modified to allow adolescents who wish to be vaccinated "despite persistent parental resistance" to provide consent for this "medically recommended and evidence-based treatment." ${ }^{11}$ In 2013, the Society for Adolescent Health and Medicine published a position paper, recommending that: "Clinicians, public health personnel, and policy makers should explore all available legal options for allowing minor adolescents with capacity for informed consent to give their own consent for vaccinations." 12

We concur that authorizing older minors to provide independent consent for recommended childhood vaccinations is an important and necessary policy reform. In this Article, we provide a comprehensive analysis of the relevant legal, bioethical, psychological, and policy issues, as well as a detailed proposal to create an exception to the default of parental consent for childhood vaccinations. We recommend that states adopt a statutory age of consent of fourteen years old for those vaccinations recommended by the Advisory Committee on Immunization Practices (ACIP). ${ }^{13}$ We further recommend that states authorize physicians to administer or authorize administration of vaccines to requesting minors ages twelve and thirteen who are capable of consenting to vaccination, consistent with the modern standards of competence detailed within. ${ }^{14}$ In states that do not pass such legislation, however, we recommend that courts adjudicating a minor's petition to receive vaccinations without parental consent adopt a treatment-specific mature minor rule that would allow those minors who

${ }^{10}$ Kevin B. O'Reilly, Highlights from the 2019 AMA Annual Meeting, AMA (June 13, 2019), https://www.ama-assn.org/house-delegates/annual-meeting/highlights-2019-ama-annual-meeting.

Furthermore, "[i]n a separate action, the delegates directed the AMA to develop model legislation for mature minor consent to vaccinations." Id.

${ }^{11}$ Ross D. Silverman et al., Vaccination Over Parental Objection-Should Adolescents Be Allowed to Consent to Receiving Vaccines?, 381 New Eng. J. Med. 104, 106 (2019). See also Soc'y for Adolescent Health \& Med., Adolescent Consent for Vaccination: A Position Paper of the Society for Adolescent Health and Medicine, 53 J. AdOLESCENT HEALTH 550, 550 (2013). For proposals focusing on minors' independent access to the vaccine for human papilloma virus (HPV), see, for example, Suchi Agrawal \& Stephanie R. Morain, Who Calls the Shots? The Ethics of Adolescent Self-Consent for HPV Vaccination, 44 J. MED. ETHICS 531, 531 (2018); Allison M. Whelan, Lowering the Age of Consent: Pushing Back Against the Anti-Vaccine Movement, 44 J.L. MED. \& ETHICs 462, 470 (2016).

${ }^{12}$ Soc'y for Adolescent Health \& Med., supra note 11, at 550. Furthermore, in December 2019, while this Article was in press, another team of pediatric experts wrote in support of this proposed policy reform. See Y. Tony Yang et al., Adolescent Consent to Vaccination in the Age of Vaccine-Hesitant Parents, 173 JAMA PEDIATRICs 1123, 1123 (2019), https://jamanetwork.com/journals/jamapediatrics/ article-abstract/2752559.

${ }^{13}$ See infra notes $27-71$ and accompanying text.

${ }^{14}$ See infra notes $328-44$ and accompanying text. 
demonstrate capacity to provide informed consent to access these vaccines independently if a physician determines a minor to be mature. Finally, we strongly recommend that the authorizing legislation require that minors' preferences regarding confidentiality be respected and that their vaccination status and vaccination-related medical contacts not be disclosed to their parents without their consent.

We do not argue here that the demonstration of adult-like health care decisionmaking capacities should lead to legal authorization for independent consent to treatment by minors more generally. In our nation, parents typically retain legal authority to make most health care decisions for their minor children, ${ }^{15}$ There are exceptions, however. The state can intervene on a case-by-case basis in medical neglect proceedings, substituting itself for the parent when it determines that a parent's failure to treat a child seriously endangers that child's health. ${ }^{16}$ A few states authorize "mature minors" to consent independently to general medical care by statute or case law. ${ }^{17}$ Most states authorize "emancipated minors" to make independent health care decisions for themselves. ${ }^{18}$ In addition, in order to achieve certain policy goals and/or to satisfy constitutional mandates, state legislatures have created several treatment-specific statutory exceptions, authorizing older minors to consent independently to the specified treatments. ${ }^{19}$

Currently, however, the law in most states does not provide a mechanism for minors to access vaccinations independent of their parents. ${ }^{20}$ In the handful of states that allows mature minors authority to consent to general medical treatment, minors who meet the legal criteria of maturity ${ }^{21}$ can be vaccinated over parental refusal. ${ }^{22}$ In addition, some states' statutory exceptions allowing minors to consent to services related to sexually

${ }^{15}$ See Doriane Lambelet Coleman \& Philip M. Rosoff, The Legal Authority of Mature Minors to Consent to General Medical Treatment, 131 PEDIATRICs 786, 789-91 (2013) (discussing which states do not allow mature minors to consent to medical treatment).

${ }^{16}$ See infra Part II.B.2.i.

${ }^{17}$ See infra Part II.B.2.ii.

${ }^{18}$ See infra note 250 .

${ }^{19}$ See infra Part II.B.2.iii.

${ }^{20}$ For a detailed, state by state table, see Table of State Laws Relevant to Minors' Consent to Vaccinations Independent of Parents, https://docs.google.com/spreadsheets/d/1uUDrkdYqzzSG9icT TSHEIWQbgtm0uFVGtBZ7rTDU8sQ/edit?usp=sharing (last visited Oct. 16, 2019). The Society for Adolescent Health and Medicine issued a position paper on adolescent consent for vaccination, interpreting state laws as somewhat more permissive of minors' authority to consent independently than our analysis suggests. Soc'y for Adolescent Health \& Med., supra note 11, at 550.

${ }^{21}$ See infra notes $22-23$.

${ }^{22}$ For example, in Alabama and Oregon, minors over a specified age can consent to treatment without parental involvement. ALA. CODE $§ 22-8-4$ (West, Westlaw through Act 2019-540); Or. REV. STAT. § 109.640 (West, Westlaw through 2018 Reg. Sess.). Certain other states allow independent treatment access by minors, conditioned on determinations of those minors' maturity or capacity to consent. See Coleman \& Rosoff, supra note 15, at 789 (noting that some jurisdictions "permit all adolescents above a certain age to consent to general medical treatment," including vaccination). 
transmitted diseases are broad enough to authorize minors to consent to vaccines for hepatitis $\mathrm{B}$ and human papilloma virus (HPV). ${ }^{23} \mathrm{~A}$ handful of legislatures are considering statutes that would authorize minors of specific ages to provide independent consent for vaccinations, although none have passed to date. ${ }^{24}$ In this Article, however, we propose a more comprehensive, treatment-specific exception that would enable older minors to consent to all of the recommended childhood vaccinations ${ }^{25}$ if their parents have not provided consent. We argue, therefore, that the default of sole parental discretion in decisionmaking for children's health care should not prevail in this context, and that this default should be supplemented by authorization of competent minors to consent independently to recommended childhood vaccinations.

$$
* * *
$$

In Part I, we establish the medical and public health foundation for our proposal. We describe the structure and substance of vaccine recommendations in the United States and provide a brief summary of the state of knowledge on vaccine safety and efficacy. We discuss current understandings of parental vaccine opposition or hesitancy and the public health crisis that has resulted from recent increases in parental non-vaccination of their children.

In Part II, we examine the legal landscape for health care decisionmaking for minors. In Section A, we discuss the legal and

${ }^{23}$ See, e.g., CAL. FAM. CODE $§ 6926$ (West, Westlaw through 2019 Reg. Sess. ch. 524) (“A minor who is 12 years of age or older . . may consent to medical care related to [prevention of a sexually transmitted disease] . ..."); DEL. CODE ANN. tit. 13, 710 (West, Westlaw through ch. 218 of the 150th General Assembly (2019-2020)) (authorizing a minor age twelve and older "who professes to be either pregnant or afflicted with contagious, infectious or communicable diseases" to consent to "any diagnostic, preventive [or medical care]"). See also Silverman et al., supra note 11, at 104 (noting that California and New York permit adolescents to consent to vaccines for hepatitis B and HPV).

${ }^{24}$ For example, in March 2019, Senate Bill 4244 was introduced in New York. The proposed text would allow minors aged fourteen and older to consent to the administration of vaccines "if the minor has capacity to consent and provides informed consent to the administering of the vaccine." S.B. 4244, 2019 Leg., 242d Sess. (N.Y. 2019). Other states considering authorizing all or some minors to consent to all or some recommended vaccines include Maryland, Public Health - Immunizations - Minor Consent (Access to Vaccines Act), H.B. 87, 441st Gen. Assemb. (Md. 2020) (authorizing minors to consent to immunizations if they are aged 16 and older who are determined to be competent to consent by a health care provider); Virginia, S.B. 104, 2020 Reg. Sess. (Va. 2020) (authorizing minors who can demonstrate decisionmaking competence to consent to vaccinations independently); Illinois, S.B. 3668, 101st Gen. Assemb., 2d Reg. Sess. (Ill. 2019) (authorizing minors aged fourteen and older to consent to immunizations with the same legal authority as an adult); New Jersey, S.B. 5399, 218th Leg., Reg. Sess. (N.J. 2019) (authorizing minors age fourteen and older to receive recommended childhood vaccines, including immunization for human papilloma virus (HPV) and hepatitis B, independent of parental consent); Washington, D.C., Minor Consent to Vaccinations Amendment Act of 2019, Washington D.C. Legislative Bill 171 (D.C. 2019) (authorizing "a minor of any age to consent to receive a vaccine where the minor is capable of [giving informed consent], and where the vaccine is recommended by [ACIP] and provided in accordance with the ACIP's recommended vaccinations schedule"); Wisconsin, Assemb.B. 863, 104th Leg. Sess., Reg. Sess. (Wis. 2019) (authorizing minors ages sixteen and older to consent independently to recommended vaccines).

${ }^{25}$ See infra notes $27-28$ and accompanying text. 
constitutional justifications for the prevailing legal mechanism governing consent for children's health care: the doctrine of parental consent. In Section B, we consider existing exceptions to that doctrine. First, we analyze the general constitutional and policy frameworks that underlie the exceptions. Second, we detail the exceptions, including those authorized by medical neglect statutes, statutory and judicial "mature" minor exceptions, and treatment-specific statutes authorizing minors' independent access to health care services.

In Part III, we lay out the arguments supporting our recommendations that certain subsets of minors be authorized to consent to vaccinations independent of their parents. In Section A, we assert that the state's interests in protecting the health of the public and individual minors and the child's interests in receiving protection from vaccine-preventable diseases converge to outweigh parental interests in sole decisionmaking authority over children's health care in the vaccination context. In Section B, we argue that statutory authorization of capable minors to consent independently to childhood vaccinations is consistent with the policies justifying existing treatment-specific exceptions to the doctrine of parental consent. In Section $\mathrm{C}$, we demonstrate that most adolescents and older preadolescents are capable of providing meaningful consent, consistent with legal standards of competence to make medical decisions. Finally, in Section D, we underscore the necessity of legal guarantees of confidentiality for minors who seek vaccinations independent of their parents. We observe that minors might be deterred from requesting vaccinations due to fear of disclosure to parents. Furthermore, in extreme cases, the welfare of minors who disregard parental objections to vaccines might be endangered by disclosure of their vaccination-related medical contacts.

Part IV details our legislative proposals and their legal, policy, and scientific justifications. Part V provides recommendations to the courts regarding adoption of a treatment-specific mature minor rule in appropriate cases, in the absence of relevant legislative action. Finally, we make concluding observations, placed in context by remarks shared with us by Ethan Lindenberger in a recent telephone interview. ${ }^{26}$

\footnotetext{
${ }^{26}$ Telephone Interview with Ethan Lindenberger, Pro-vaccination Activist, via Skype (June 16, 2019) (recording on file with authors). Eighteen-year-old Ethan Lindenberger made national news when he testified before Congress regarding his mother's opposition to vaccinations, and his decision to become vaccinated as soon as he was legally capable of doing so. See generally James Doubek, 18-Year-Old Testifies About Getting Vaccinated Despite Mother's Anti-Vaccine Beliefs, NPR (Mar. 6, 2019), https://www.npr.org/2019/03/06/700617424/18-year-old-testifies-about-getting-vaccinateddespite-mothers-anti-vaccine-beli (discussing Lindenberger's testimony before Congress).
} 


\section{VACCINES, THE ANTI-VACCINE MOVEMENT, AND THE VACCINATION CRISIS}

\section{A. Recommended Vaccines' Risks and Benefits}

The Advisory Committee on Immunization Practices (ACIP) currently recommends that children in the United States routinely be vaccinated against fifteen diseases before the age of eighteen. Children under age two are recommended to receive vaccines to protect them from thirteen diseases: diphtheria, haemophilus influenzae type $\mathrm{b}$, hepatitis A, hepatitis B, influenza (an annual vaccine), measles, mumps, pertussis, pneumococcal disease, polio, rotavirus, rubella, and varicella (chicken pox). ${ }^{27}$ It is recommended that preteens receive vaccinations to protect them from meningococcal disease and HPV. ${ }^{28}$ In determining whether to recommend vaccines, the ACIP requires that the benefits outweigh the risks and that the recommendation be cost-effective. ${ }^{29}$ After the Committee recommends vaccines, the Director of the Centers for Disease Control and Prevention (CDC) considers those recommendations, together with input from the American Academy of Pediatrics and the American Academy of Family Physicians, and makes its own authoritative recommendations. ${ }^{30}$ Generally, the CDC Director accepts ACIP recommendations. ${ }^{31}$

Although vaccine recommendations are made by the $\mathrm{CDC}$, a federal agency, there are currently no federal vaccine mandates in the United States. Rather, in the United States, the authority to mandate vaccine compliance rests primarily with the states, which determine which vaccines are required prior to school entry. ${ }^{32}$ Generally, states require some subset of those vaccines recommended by ACIP, although the specifics of state requirements vary across the nation. ${ }^{33}$

Emphasizing the high benefit and low cost ratio characterizing recommended vaccines, the National Academies of Science, Engineering, and Medicine concluded that vaccines "have many health benefits and few

27 Ctrs. For Disease Control \& PREvention, Recommended Child AND Adolescent IMMUNIZATION SCHEDULE FOR AGES 18 YeARS OR YOUNGER tbl.1 (2019), https://www.cdc.gov/vaccines/schedules/hcp/imz/child-adolescent.html\#birth-15 (last visited July 18, 2019).

${ }^{28} I d$.

${ }^{29}$ Jean Clare Smith, The Structure, Role, and Procedures of the U.S. Advisory Committee on Immunization Practices (ACIP), 285 VACCINE A68, A72 (2010).

${ }^{30} \mathrm{Id}$. at $\mathrm{A} 72-\mathrm{A} 73$.

${ }^{31} \mathrm{Id}$. at $\mathrm{A} 73$.

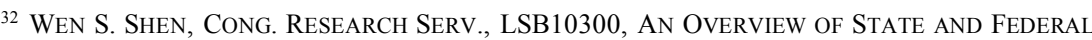
$\begin{array}{llllll}\text { AUTHORITY TO IMPOSE VACCINATION REQUIREMENTS } & 1 & \text { (2019) }\end{array}$ https://fas.org/sgp/crs/misc/LSB10300.pdf.

${ }^{33}$ Reiss \& Weithorn, Responding to the Childhood Vaccination Crisis, supra note 7, at 892-93. 
side effects." 34 Indeed, there is a global expert consensus that vaccines are both safe and effective. ${ }^{35}$ This is, of course, a generalization: nothing is $100 \%$ safe or $100 \%$ effective (and no "consensus" is $100 \%$ ). It does, however, mean that vaccines' benefits are substantial, vaccines' risks are low, and that the benefits far outweigh the risks. The World Health Organization has emphasized that "[t]here is arguably no single preventive health intervention more cost-effective than immunization. Time and again, the international community has endorsed the value of vaccines and immunization to prevent and control a large number of infectious diseases and, increasingly, several chronic diseases that are caused by infectious agents." 36

Extensive data reveals that vaccines dramatically reduce the burden of disease. ${ }^{37}$ Public health experts estimated, for example, that over the course of the lives of children born from 1994 to 2013, routine vaccination will prevent "322 million illnesses, 21 million hospitalizations, and 732,000 deaths . . . at a net savings of \$295 billion in direct costs and \$1.38 trillion in total societal costs." 38 Globally, the World Health Organization estimates that vaccines save 2 to 3 million lives annually, and that another 1.5 million lives could be saved if vaccination programs were fully implemented worldwide. $^{39}$

Some vaccines are more effective than others. For instance, the measles, mumps, and rubella vaccine (MMR) is highly effective against measles. ${ }^{40}$ The influenza vaccine is less effective, ${ }^{41}$ although it still prevents deaths and

\footnotetext{
${ }^{34}$ Vaccines Are Safe, NAT’L. ACAD. SCI. ENGINEERING \& MED., http://sites.nationalacademies.org/ BasedOnScience/vaccines-are-safe/ (last visited Mar. 16, 2020).

${ }^{35}$ Francis E. Andre et al., Vaccination Greatly Reduces Disease, Disability, Death and Inequity Worldwide, 86 Bull. WORLD HEALTH ORG. 140, 140 (2008), https:/www.who.int/bulletin/volumes/ 86/2/07-040089/en/.

${ }^{36}$ Ten Facts on Immunization, WORLD HEALTH ORG., http://origin.who.int/features/factfiles/ immunization/en/ (last updated Mar. 2018).

${ }^{37}$ Sandra W. Roush \& Trudy V. Murphy, Historical Comparisons of Morbidity and Mortality for Vaccine-Preventable Diseases in the United States, 298 JAMA 2155, 2156-59 tbls.1-2 (2007); Cynthia G. Whitney et al., Benefits from Immunization During the Vaccines for Children Program Era - United States, 1994-2013, 63 MORBIDITY \& MORTALITY WKLY. ReP. 352, 352-55 (2014), https://www.cdc.gov/mmwr/preview/mmwrhtml/mm6316a4.htm.

${ }^{38}$ Whitney et al., supra note 37 , at 352 .

${ }^{39}$ WORLD HEALTH ORG., supra note 36.

${ }^{40}$ Ctrs. For Disease Control \& Prevention, Epidemiology and Prevention of VaccinePREVENTABLE DisEASES 218 (Jennifer Hamborsky et al. eds., 13th ed. 2015) [hereinafter PINK BoOK] ("Studies indicate that more than $99 \%$ of persons who receive two doses of measles vaccine (with the first dose administered no earlier than the first birthday) develop serologic evidence of measles immunity.").

${ }^{41}$ CDC Seasonal Flu Vaccine Effectiveness Studies, CENTERS fOR DISEASE CONTROL \& PREVENTION, https://www.cdc.gov/flu/vaccines-work/effectiveness-studies.htm (last visited July 18, 2019).
} 
other adverse effects of disease, especially in children. ${ }^{42}$ Both the polio ${ }^{43}$ and hepatitis B vaccines ${ }^{44}$ are extremely effective, protecting over $95 \%$ of recipients. In addition to reducing deaths and suffering, vaccines dramatically reduce costs to society and individuals, saving billions of dollars annually. ${ }^{45}$ Vaccines also have positive effects on health equity and lead to other social benefits. ${ }^{46}$ In short, all routinely recommended vaccines have considerable benefits, both for the individual and for society.

Vaccines protect not only those individuals who are vaccinated from becoming infected, they also confer an additional benefit through community (or herd) immunity. When enough people in a community are vaccinated, others at risk of infection from the disease are also protected. These other beneficiaries include those who cannot safely be vaccinated for medical reasons, those who are too young to be fully vaccinated, those within the small minority of persons for whom vaccinations did not create immunity, and those who are intentionally unvaccinated. ${ }^{47}$ Thus, when parents vaccinate their child, they protect not only their child through direct action, but also others in the community who, as noted above, are not or cannot be fully vaccinated. And conversely, parents who do not vaccinate are creating a risk not just for their own child, but also for other unprotected individuals. As the number of unvaccinated children in the community increases, the risk of outbreak also increases, putting anyone who is

${ }^{42}$ See Brendan Flannery et al., Influenza Vaccine Effectiveness Against Pediatric Deaths: 2010-2014, 139 PeDiatrics 1, 1-8 (2017) (reporting rates of infection and death from influenza in children); Karen K. Wong et al., Influenza Associated Pediatric Deaths in the United States 2004-2012, 132 PeDiATRICs 796, 796-803 (2013) (same); see also Faruque Ahmed et al., Effect of Influenza Vaccination of Healthcare Personnel on Morbidity and Mortality Among Patients: Systematic Review and Grading of Evidence, 58 CLINICAL INFECTIOUS DiSEASES 50, 50, 52-56 (2014) (reporting data relevant to rates of infection among health care personnel); E. Amodio et al., Can Influenza Vaccination Coverage Among Healthcare Workers Influence the Risk of Nosocomial Influenza-Like Illness in Hospitalized Patients?, 86 J. HOSP. INFECTION 182, 182-86 (2014) (same).

${ }^{43}$ The CDC estimates that $99 \%$ of people who received three doses of inactivated polio vaccine are immune. PINK BOOK, supra note 40, at 302-03.

${ }^{44}$ The hepatitis B vaccine is $95 \%$ effective in children, but is slightly less effective in adults. PINK BooK, supra note 40, at 159 ("After three intramuscular doses of hepatitis B vaccine, more than $90 \%$ of healthy adults and more than $95 \%$ of infants, children, and adolescents [from birth to nineteen years of age] develop adequate antibody responses.").

${ }^{45}$ Fangjun Zhou et al., Economic Evaluation of the Routine Childhood Immunization Program in the United States, 2009, 133 PEDIATRICS 577, 581 (2014) (analyzing efficacy and cost-effectiveness of immunization initiative); see Charlotte A. Moser et al., Funding the Costs of Disease Outbreaks Caused by Non-Vaccination, 43 J.L. MED. \& ETHICS 633, 633 (2015) (analyzing the economic burden of nonvaccination patterns and related disease outbreaks).

${ }^{46}$ See Jeroen Luyten \& Philippe Beutels, The Social Value of Vaccination Programs: Beyond Cost-Effectiveness, 35 HeALTH AFF. 212, 212-17 (2016) (recommending broad, multidimensional evaluations of vaccination programs that expand beyond economic variables, also incorporating assessment of social and ethical impacts).

${ }^{47}$ T. Jacob John \& Reuben Samuel, Herd Immunity and Herd Effect: New Insights and Definitions, 16 Eur. J. EPIDEMIOLOGY 601, 602-03 (2000); see also Dorit Rubinstein Reiss, Herd Immunity and Immunization Policy: The Importance of Accuracy, 94 OR. L. REV. 1, 14-16 (2015). 
vulnerable at risk. ${ }^{48}$ The decision not to vaccinate, therefore, has substantial implications beyond the immediate family.

Thus, vaccines have substantial individual and social benefits. That said, nothing is risk free, and vaccines, too, have risks. Those risks, however, are relatively low. The World Health Organization Bulletin explains that:

[I]ndependent experts and WHO have shown that vaccines are far safer than therapeutic medicines. Modern research has spurred the development of less reactogenic products, such as acellular pertussis vaccines and rabies vaccines produced in cell culture. Today, vaccines have an excellent safety record and most "vaccine scares" have been shown to be false alarms. $^{49}$

In contrast to the low risks posed by immunizations for these diseases, the risks posed by the vaccine-preventable diseases are significant. For example, polio led to tens of thousands of cases of paralysis and over a thousand deaths each year in the United States before vaccines led to the elimination of polio. ${ }^{50}$ The Oral Polio Vaccine-which is no longer used in the United States ${ }^{51}$ - also presented its own risks, however. It could cause paralysis in approximately six to ten cases a year. ${ }^{52}$ The incidence of paralysis with the vaccination occurred at a substantially lower rate than that which occurred with infection from the polio virus. ${ }^{53}$ Yet, when it occurred, of course, it was still a tragedy for the families affected. The currently used Inactivated Polio Vaccine (IPV) does not present the same risk. The IPV has

${ }^{48}$ See Paul Fine et al., "Herd Immunity": A Rough Guide, 52 CLINICAL INFECTIOUS DISEASES 911, 914 (2011) (footnote omitted) ("Social clustering among parents who decide not to vaccinate their children can result in groups of children in which vaccination levels are well below the herd immunity threshold. The same effect is found in religious communities that eschew vaccination . . .."); see also Jessica E. Atwell et al., Nonmedical Vaccine Exemptions and Pertussis in California, 2010, 132 PEDIATRICS 624, 627 (2013) (analyzing the association of "geographic areas with high rates of [nonmedical vaccine exemptions]" and "high rates of pertussis"); Saad B. Omer et al., Geographic Clustering of Nonmedical Exemptions to School Immunization Requirements and Associations with Geographic Clustering of Pertussis, 168 AM. J. EPIDEMIOLOGY 1389, 1394 (2008) (discussing the significant overlap between clusters of exemptions and clusters of pertussis cases); Jennifer L. Richards et al., Nonmedical Exemptions to Immunization Requirements in California: A 16-Year Longitudinal Analysis of Trends and Associated Community Factors, 31 VACCINE 3009, 3012 (2013) (reporting that geographic areas with high rates of nonmedical exemptions were also associated with high rates of pertussis in California between 1994 and 2009).

${ }^{49}$ Andre et al., supra note 35, at 140 (citations omitted).

${ }^{50}$ PINK BoOK, supra note 40, at 297-98.

${ }^{51} \mathrm{Id}$. at 302 .

${ }^{52}$ Id. at 301 ("From 1980 through 1999, a total of 162 confirmed cases of paralytic poliomyelitis were reported, an average of 8 cases per year. Six cases were acquired outside the United States and imported.").

${ }^{53} I d$. at 299-300, 303 (demonstrating that this vaccine led to eight to ten cases of paralysis annually until its replacement by the inactivated vaccine). 
fairly minimal side effects: minor local reactions and a theoretical (although not observed) risk of allergic reaction. ${ }^{54}$ It is clear that those risks are both absolutely low, and substantially lower than those of the polio virus.

Figure 1: Polio Risks v. Polio Vaccine Risks

\begin{tabular}{|l|l|}
\hline $\begin{array}{l}\text { Risks of Polio Virus } \\
\text { About 1:200 Paralyzed } \\
\text { Death }\end{array}$ & $\begin{array}{l}\text { OPV (not used in United States anymore): } \\
1: 2-3 \text { million paralyzed. }\end{array}$ \\
\hline $\begin{array}{l}\text { IPV (currently used): } \\
\text { Local reactions. } \\
\text { Theoretical risk of allergic reaction to } \\
\text { antibiotics-never seen in practice. }\end{array}$ \\
\hline
\end{tabular}

Measles - as another example — can cause complications in about $29 \%$ of people who get the disease, including pneumonia in over $5 \%$, death in about 1 to 3 in a thousand, and encephalitis in 1 per thousand - and that is in developed countries. ${ }^{55}$ It can cause subacute sclerosing panencephalitis (SSPE), an always fatal complication that leads to a slow, lingering death. ${ }^{56}$ Scientists once thought this complication was very rare, but recent studies reveal a higher incidence than initially reported when the measles patient is young. ${ }^{57}$ Even a routine case of measles (without complications) typically produces high fever that typically lasts at least a week. ${ }^{58}$ The CDC estimates that three to four million children were infected with measles each year in the United States before the advent of the vaccine. ${ }^{59}$ The present rate of measles infection in the United States is the highest rate since $1992 .{ }^{60}$

\footnotetext{
${ }^{54}$ Id. at 306.

${ }^{55}$ Robert T. Perry \& Neal A. Halsey, The Clinical Significance of Measles: A Review, 189 J. INFECTIOUS DISEASES S4, S7 (2004). The rate of harm is, of course, higher in underdeveloped countries.

${ }^{57}$ See Katharina Schönberger et al., Epidemiology of Subacute Sclerosing Panencephalitis (SSPE) in Germany from 2003 to 2009: A Risk Estimation, PLOS (2013), https://journals.plos.org/plosone/article ?id=10.1371/journal.pone.0068909 (estimating the risk at 1:1700 to 1:3300 in children under age five); Kristen Wendorf et al., Subacute Sclerosing Panencephalitis: The Devastating Measles Complication Is More Common Than We Think, 3 OPEN F. INFECTIOUS DISEASE 916, 916 (2016) (estimating the rate at 1:1367 for children under five, and a terrifying 1:609 for infants who contract measles before the age of

${ }^{58}$ Perry \& Halsey, supra note 55, at S4.

59 Measles History, Centers FOR Disease CONTROL \& Prevention, https://www.cdc.gov/ measles/about/history.html (last reviewed Feb. 5. 2018).

${ }^{60}$ See supra notes $4-5$ and accompanying text.
} one). 
The MMR, which protects against measles, mumps, and rubella, led to dramatic reduction in measles cases and attendant harms. ${ }^{61}$ Of 500,000 reported cases before the availability of effective vaccines, there were four to five hundred deaths and tens of thousands of hospitalizations. ${ }^{62}$ This contrasts with the risks of the MMR, which include fever in $5 \%$ to $15 \%$ of children; a mild, non-contagious rash in 5\% of children; febrile seizures (which are scary, but usually harmless) in about 1 in 2300 to 2600 children; a blood platelet disorder (thrombocytopenia) in about 1 in 30,000 cases; and very rarely, an allergic reaction. ${ }^{63}$ Thrombocytopenia is less common when it occurs following administration of the MMR than it is as a complication of measles. Furthermore, thrombocytopenia is usually short-lived when it follows MMR administration: over $90 \%$ of children overcome it in six weeks. ${ }^{64}$ Temporary arthralgia (that is, joint pain) is fairly common (up to $25 \%$ ) in adult women who receive the MMR. The CDC explains: "Joint pain or stiffness occurs in up to 1 in 4 of females past puberty who were not previously immune to rubella; their symptoms generally begin 1 to 3 weeks after vaccination, are usually mild and last about 2 days. These symptoms rarely come back." 65

While these vaccine side effects and complications, ranging from temporarily unpleasant to serious, are not insignificant, serious reactions from MMR are rare. ${ }^{66}$ In spite of anti-vaccine movement claims, the $M M R$ is not linked to autism. ${ }^{67}$ Most recently, a study of over 650,000 children in Denmark reaffirmed the extensive existing literature, finding no increased risk of autism with MMR vaccination. ${ }^{68}$ Indeed, "studies in three continents

61 See Measles Cases and Outbreaks, Centers fOr Disease CONTROL \& Prevention, https://www.cdc.gov/measles/cases-outbreaks.html (last reviewed Oct. 11, 2019) (finding that the majority of people who contracted measles were unvaccinated).

${ }^{62}$ PINK BOOK, supra note 40, at 214.

${ }^{63} \mathrm{Id}$. at 226.

${ }^{64}$ E. Miller et al., Idiopathic Thrombocytopenic Purpura and MMR Vaccine, 84 ARCHIVES DISEASE CHILDHOOD 227, 228 (2001), https://adc.bmj.com/content/84/3/227.full.

${ }^{65}$ Measles, Mumps and Rubella (MMR) Vaccine Safety, CENTERS FOR DiSEASE CONTROL \& PREVENTION, https://www.cdc.gov/vaccinesafety/vaccines/mmr-vaccine.html (last reviewed Jan. 29, 2020).

${ }^{66}$ Nicola P. Klein et al., Safety of Measles-Containing Vaccines in 1-year-old Children, 135 Pediatrics e321, e321 (2015); Annamari Patja et al., Serious Adverse Events After Measles-Mumps-Rubella Vaccination During a Fourteen-Year Prospective Follow-Up, 19 PediATRIC INFECTIOUS DISEASES J. 1127, 1127 (2000).

${ }^{67}$ Most recently, seventeen studies examining 657,461 children found no link between MMR and autism. Anders Hviid et al., Measles, Mumps, Rubella Vaccination and Autism: A Nationwide Cohort Study, 170 AnN. InTERNAL Med. 513, 513 (2019). See also Dorit Rubinstein Reiss \& John Diamond, Measles and Misrepresentation in Minnesota: Can There Be Liability for Anti Vaccine Misinformation that Causes Bodily Harm?, 56 SAN Diego L. REV. 531, 562-63 (2019); Jeffrey S. Gerber \& Paul A. Offit, Vaccines and Autism: A Tale of Shifting Hypotheses, 48 CLINICAL INFECTIOUS DiSEASES 456, 456 58 (2009).

${ }^{68}$ Hviid et al., supra note 67, at 513-14. 
spanning millions of children [have] found no link between the MMR and autism. ${ }^{69}$

Figure 2: Risks of Measles v. Risks of MMR:

\section{Risks of Measles}

Ear infections

Croup

Diarrhea

$5 \%$ pneumonia

1:1000 encephalitis, almost $50 \%$

mortality.

1-3:1000 deaths.

SSPE: Germany: 2003-2009

1:1750-3300 in kids under 5.

California: 1:660 in infants.

\section{Risks of MMR}

Local reactions

Fever

Febrile Seizures

ITP: 1:24,000, usually temporary.

Severe allergic reaction $1: 1.5-1.8$ million.

More generally, the most serious risk from vaccines are probably severe allergic reactions which occur about once in a million doses. ${ }^{70}$ As this discussion demonstrates, the risks of modern vaccines are both absolutely and relatively low when compared to the benefits. ${ }^{71}$

\section{B. Why Don't Parents Vaccinate?}

An extensive body of literature ${ }^{72}$ addresses the question of why people do not vaccinate. We touch on key points here. Several studies have examined the reasons provided by parents when asked why they do not vaccinate. Beyond the articulated justifications, parents' values may affect their susceptibility to specific anti-vaccine arguments. Furthermore, parents' social networks influence their views.

\footnotetext{
${ }^{69}$ Reiss \& Diamond, supra note 67 , at 562-63 (providing a detailed overview of the MMR and autism studies).

${ }^{70}$ Michael M. McNeil et al., Risk of Anaphylaxis After Vaccination in Children and Adults, $137 \mathrm{~J}$. ALLERGY \& CLINICAL IMMUNOLOGY 868, 868 (2016).

${ }^{71}$ See also Reiss \& Weithorn, Responding to the Childhood Vaccination Crisis, supra note 7, at $885-88$.

${ }^{72}$ For examples of such literature, see generally PaUl A. OfFit, DeAdly Choices: How the

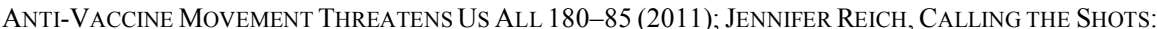
Why PAREnTs Reject VACCInes (2016); Melissa B. Gikey et al., Forgone Vaccination During Childhood and Adolescence: Findings of a Statewide Survey of Parents, 56 PREVENTIVE MED. 202 (2013); Edward Mills et al., Systematic Review of Qualitative Studies Exploring Parental Beliefs and Attitudes Toward Childhood Vaccination Identifies Common Barriers To Vaccination, 58 J. CLINICAL EPIDEMIOLOGY 1081 (2005); Douglas J. Opel \& Edgar K. Marcuse, Window or Mirror: Social Networks ' Role in Immunization Decisions, 131 PEDIATRICS 1619 (2013).
} 
We have examined the literature on the rationales for parents' refusal to vaccinate in detail elsewhere. ${ }^{73}$ We pointed out that the reasons include (generally ill-founded) safety concerns, misconceptions about preventable diseases that underestimate disease risks and the efficacy of vaccines, distrust of doctors and government (shading, in the extreme, into conspiracy theories), preferences for alternative medicine as well as "natural" approaches to health without scientific foundation, and a view that governmental vaccination policies reflect unjustified governmental intrusion that violate their civil rights. ${ }^{74}$ In addition, occasionally religious beliefs underlie parental objections. ${ }^{75}$ While some parents' objections to vaccines may be grounded in sincere religious views, courts and commentators have concluded that such assertions at times mask the parents' true reasons for their anti-vaccine positions. ${ }^{76}$ There is substantial variability in the rationales and degree of tenacity in parental opposition to vaccines. Vaccine-hesitant parents may be more open to persuasion by their children if the children wish to be vaccinated. By contrast, vaccine-rejector parents typically repel any form of persuasion. The repercussions for minors who request vaccination over parental opposition may be most severe when parents are vaccine-rejectors. ${ }^{77}$

Parents who refuse vaccines typically voice deep and consistent concerns about the harms they believe are associated with vaccines. ${ }^{78}$ Typically, however, the information that leads parents to think vaccines' risks are high is misleading or patently false. For example, scientific data do not support parental beliefs that vaccines weaken the immune system or that the recommended vaccine schedule gives infants too many vaccines too soon. Multiple vaccines on the schedule are not harmful in combination (and challenge babies' immune systems to a lesser degree than other natural exposures), and have important benefits. ${ }^{79}$ Concerns about vaccines'

\footnotetext{
${ }^{73}$ Reiss \& Weithorn, Responding to the Childhood Vaccination Crisis, supra note 7, at 937-52.

${ }^{74} \mathrm{Id}$. at 937.

${ }^{75}$ Anat Gesser-Edelsburg et al., Why Do Parents Who Usually Vaccinate Their Children Hesitate or Refuse? General Good vs. Individual Risk, 19 J. RISK RES. 405, 408 (2014).

${ }^{76}$ Dorit Rubinstein Reiss, Thou Shalt Not Take the Name of the Lord Thy God in Vain: Use and Abuse of Religious Exemptions from School Immunization Requirements, 65 HASTINGS L.J. 1551, 1570 88 (2014)

${ }^{77}$ E. Allison Hagood \& Stacy Mintzer Herlihy, Addressing Heterogeneous Parental Concerns About Vaccination with a Multiple-Source Model: A Parent and Educator Perspective, 9 HuM. VACCINES \& IMMUNOTHERAPEUTICS 1790, 1791 (2013).

${ }^{78}$ ReICH, supra note 72, at 79-86; Mabel Berezin \& Alicia Eads, Risk Is for the Rich? Childhood Vaccination Resistance and a Culture of Health, 165 SoC. SCI. \& MED. 233, 234-35 (2016); Chephra McKee \& Kristin Bohannon, Exploring the Reasons Behind Parental Refusal of Vaccines, $21 \mathrm{~J}$. Pediatric Pharmacology \& Therapeutics 104, 104 (2016); Daniel A. Salmon et al., Factors Associated with Refusal of Childhood Vaccines Among Parents of School Aged Children: A Case-Control Study, 159 ARChIVES Pediatric Adolescent Med. 470, 471 (2005).

${ }^{79}$ Francesco Nicoli \& Victor Appay, Immunological Considerations Regarding Parental Concerns on Pediatric Immunizations, 35 VACCINE 3012, 3015 (2017); Paul A. Offit et al., Addressing Parents'
} 
ingredients raised on anti-vaccine sites ${ }^{80}$ are also unfounded. The ingredients in vaccines that concern some parents occur in amounts that do not present a danger to the child. ${ }^{81}$ For example, formaldehyde is present in vaccines in amounts that are substantially less than that which an infant's body produces naturally as part of the infant's own metabolism. ${ }^{82}$ Extensive evidence shows that vaccines do not cause autism, ${ }^{83}$ food allergies, ${ }^{84}$ or Sudden Infant Death Syndrome. ${ }^{85}$ Furthermore, parents also substantially underestimate the risks posed by the diseases that vaccines prevent. ${ }^{86}$ Ironically, at least in part, the success of vaccines in preventing disease has contributed to the problem. ${ }^{87}$ In other words, as vaccines have led to the disappearance of some diseases, parents unfamiliar with the dangers of vaccine-preventable diseases disbelieve the evidence on the benefits of these life-saving interventions, and

Concerns: Do Too Many Vaccines Overwhelm or Weaken the Infant's Immune System?, 109 PEDIATRICS 124, 124-25 (2002).

${ }^{80}$ Anna Kata, Anti-Vaccine Activists, Web 2.0, and the Postmodern Paradigm-An Overview of Tactics and Tropes Used Online By the Anti-Vaccination Movement, 30 VACCINE 3778, 3781 (2012).

${ }^{81}$ The amount of pork gelatin in vaccines, however, may be associated with allergic reactions in about one per two million people. Paul A. Offit \& Rita K. Jew, Addressing Parents' Concerns: Do Vaccines Contain Harmful Preservatives, Adjuvants, Additives, or Residuals?, 112 PEDIATRICS 1394, 1397 (2003). For additional information, see also Vaccine Educ. Ctr., Vaccine Ingredients, CHILD. HosP. PHILA., https://www.chop.edu/centers-programs/vaccine-education-center/vaccine-ingredients (last reviewed Oct. 28, 2019).

82 Vaccine Educ. Ctr., Vaccine Ingredients - Formaldehyde, CHILD. HosP. PHILA., https://www.chop.edu/centers-programs/vaccine-education-center/vaccine-ingredients/formaldehyde (last reviewed May 14, 2018).

${ }^{83}$ See notes 67-69 and accompanying text. Most recently, a large study of MMR vaccine found no link to autism. See Hviid et al., supra note 67, at 513. Previously, a meta-analysis examining studies involving over one million children reached the same conclusion, Luke E. Taylor et al., Vaccines Are Not Associated with Autism: An Evidence-Based Meta-Analysis of Case-Control and Cohort Studies, 32 VACCINE 3623, 3623 (2014), as did an Institute of Medicine Report about vaccines' adverse events, Margaret A. Maglione et al., Safety of Vaccines Used for Routine Immunization of US Children: A Systematic Review, 134 Pediatrics 325, 325 (2014). See also Frank DeStefano, Heather Monk Bodenstab \& Paul A. Offit, Principal Controversies in Vaccine Safety in the United States, 69 CLINICAL INFECTIOUS DISEASES 726, 726 (2019).

${ }^{84}$ Paul A. Offit \& Charles J. Hackett, Addressing Parents' Concerns: Do Vaccines Cause Allergic or Autoimmune Diseases?, 111 PEDIATRICS 653, 653 (2003); see also Vaccine Educ. Ctr., Vaccines and Asthma or Allergies: Do Vaccines Cause Asthma or Allergies?, CHILD. HosP. PHILA., https:/www.chop.edu/centers-programs/vaccine-education-center/vaccines-and-other-conditions/ vaccines-asthma-allergies (last reviewed Oct. 10, 2017).

${ }^{85}$ Pedro L. Moro et al., Deaths Reported to the Vaccine Adverse Event Reporting System, United States, 1997-2013, 61 VACCINES 980, 980-84 (2015); Giuseppe Traversa et al., Sudden Unexpected Deaths and Vaccinations During the First Two Years of Life in Italy: A Case Series Study, 6 PLOS ONE e16363, e16363 (2011); Y. Tony Yang \& Jana Shaw, Sudden Infant Death Syndrome, Attention-Deficit/Hyperactivity Disorder and Vaccines: Longitudinal Population Analyses, 36 VACCINE 595, 595 (2018); M.M.T. Vennemann et al., Sudden Infant Death Syndrome: No Increased Risk After Immunisation, 25 VACCINE 336, 336-37 (2007).

${ }^{86}$ See Mark Doherty et al., Vaccine Impact: Benefits for Human Health, 34 VACCINE 6707, 6711 (2016) (discussing the re-emergence of vaccine-preventable diseases and the implications for unimmunized persons in a community)

${ }^{87}$ See id. at 6709 (examining the success of vaccines in reducing childhood mortality). 
focus instead on the more visible, albeit lesser, risks and costs of the vaccines. ${ }^{88}$

In short, most of the beliefs that typically lead parents to refuse vaccination are without scientific foundation. Anti-vaccine websites mislead parents who, seeking to choose the lesser risk for their children, ultimately choose the greater risk. ${ }^{89}$ These parents then also, intentionally or unintentionally, place others at risk because unvaccinated children are at higher risk of becoming infected and transmitting diseases to other intentionally unvaccinated individuals: the small percentage of persons for whom vaccines are not effective; those too young to be vaccinated; and those with medical conditions that preclude some or all vaccinations, such as transplant recipients or immunocompromised individuals. ${ }^{90}$

In her book Calling the Shots: Why Parents Reject Vaccines, scholar Jennifer Reich places vaccine refusal in a broader social and cultural context. ${ }^{91}$ She points out that modern society directs people to be "informed consumers," challenging the pronouncements of scientific and governmental authorities and performing "research" themselves. ${ }^{92}$ Vaccine-rejecting parents see themselves as "researchers" of that variety. They perceive themselves to be self-educating, as informed consumers, in order to make good decisions for their children. ${ }^{93}$ Similarly, vaccine refusers' views fit well within an age of personalization, explains Reich, and a call to personalize both consumption and medicine. ${ }^{94}$

Even more broadly, a new body of literature examines the role of values in vaccine refusal. Scholars find that parents who are strongly vaccine hesitant are more likely than others to value purity (that is, placing an emphasis on avoiding anything considered "disgusting" or "unnatural" and expressing concerns about vaccines' content) and liberty (that is, valuing personal choice).$^{95}$ That literature suggests that different messaging might be more successful in influencing parents who oppose vaccines. ${ }^{96}$

\footnotetext{
${ }^{88} \mathrm{Id}$. at 6708 .

${ }^{89}$ Kata, supra note 80, at 3779; Meghan Bridgid Moran et al., What Makes Anti-Vaccine Websites Persuasive? A Content Analysis of Techniques Used by Anti-Vaccine Websites to Engender Anti-Vaccine Sentiment, 9 J. Comm. HealthCare 151, 151-53 (2016); Richard K. Zimmerman et al., Vaccine Criticism on the World Wide Web, 7 J. MED. INTERNET RES. e17, e17 (2005).

90 See generally IMMUNIZATION ACTION COAL., PERSONAL BELIEF EXEMPTIONS FOR VACCINATION PUt PEOPle AT Risk. EXAMINE THE EVIDENCE FOR YOURSElF (2019), http://www.immunize.org/catg.d/p2069.pdf (citing studies demonstrating higher risk from unvaccinated individuals).

${ }^{91}$ ReICH, supra note 72 , at $67-75$.

${ }^{92} \mathrm{Id}$. at $72-75$.

${ }^{93} \mathrm{Id}$.

${ }^{94}$ Id. at $87-89$.

${ }^{95}$ Avnika B. Amin et al., Association of Moral Values with Vaccine Hesitancy, 1 NATURE HuM. BEHAV. 873, 873 (2017).

${ }^{96}$ Noel T. Brewer et al., Increasing Vaccination: Putting Psychological Science into Action, 18 PSYCHOL. SCI. PUB. INT. 149, 150 (2017).
} 
Finally, we observe that vaccine refusal is highly socially embedded. Local attitudes and virtual social networks can influence a person's vaccine hesitancy. ${ }^{97}$ These networks are also "contagious," traveling from one community to another. ${ }^{98}$ Social networks support and reinforce parental decisions not to vaccinate. ${ }^{99}$ In a community with high rates of vaccine hesitancy, a minor's choice to be vaccinated may have stronger social repercussions for the minor and the minor's family than in other communities, thus creating "counter pressure," and thereby strengthening parental opposition to a minor's vaccination request. ${ }^{100}$

\section{AUTHORITY FOR HEALTH CARE DECISIONS FOR MINORS: THE LEGAL LANDSCAPE}

\section{A. The Doctrine of Parental Consent}

It is well-established that in the United States, parents and guardians retain legal authority to make health care decisions for their minor children. This doctrine of parental consent is but one facet of the broad authority vested in parents to make decisions affecting the welfare of their minor children. ${ }^{101}$ In 2000, the U.S. Supreme Court reflected that the "the interest of parents in the care, custody, and control of their children" is "perhaps the oldest of the fundamental liberty interests recognized by this Court." 102 The state gives parents a relatively wide berth with which to carry out their responsibilities vis-à-vis their children. ${ }^{103}$ Now recognized as a veritable fixture in American law, parental discretion in decisionmaking concerning minor children is the starting point for most analyses of decisional authority

\footnotetext{
${ }^{97}$ Katie Attwell et al., The Social Basis of Vaccine Questioning and Refusal: A Qualitative Study Employing Bourdieu's Concepts of 'Capitals' and 'Habitus', 15 InT'L J. ENVTL. RES. PUB. Health 1044, 1044 (2018); Heidi Y. Lawrence et al., Reframing Medicine's Publics: The Local as a Public of Vaccine Refusal, 35 J. MED. Human. 111, 111 (2014); Marcel Salathé \& Sabastian Bonhoeffer, The Effect of Opinion Clustering on Disease Outbreaks, 5 J. ROYAL SOC'Y INTERFACE 1505, 1508 (2008).

${ }_{98}$ Ellsworth Campbell \& Marcel Salathé, Complex Social Contagion Makes Networks More Vulnerable to Disease Outbreaks, 3 SCI. REP. 1, 1-2 (2013); Y. Tony Yang, George Washington Univ., Why Stricter Immunization Laws Are Justified? Empirical Evidence of Nonmedical Exemptions' Contagiousness (Nov. 2019), https://apha.confex.com/apha/2019/meetingapi.cgi/Paper/454274? filename $=2019$ Abstract 454274. html\&template $=$ Word.

${ }^{99}$ Jennifer A. Reich, "We Are Fierce, Independent Thinkers and Intelligent”: Social Capital and Stigma Management Among Mothers Who Refuse Vaccines, Soc. SCI. \& MED., July 2020, at 1, 1-4, https://www.sciencedirect.com/science/article/abs/pii/S0277953618306233.

${ }^{100} I d$. at 4.

${ }^{101}$ See, e.g., Wisconsin v. Yoder, 406 U.S. 205, 232 (1972) ("The primary role of the parents in the upbringing of their children is now established beyond debate as an enduring American tradition.").

${ }^{102}$ Troxel v. Granville, 530 U.S. 57, 65-66 (2000).

${ }^{103}$ See Prince v. Massachusetts, 321 U.S. 158, 166 (1944) (stating that the primacy of the parents in raising their children leads the Court to respect a "private realm of family life which the state cannot enter").
} 
regarding children or adolescents. ${ }^{104}$ Yet, it is not necessarily the ending point. The law governing health care decisions for minors reveals a complex array of exceptions to the doctrine of parental consent, each of which provides for a decisionmaking mechanism to supplement, or in some cases replace, parental discretion.

Although principles governing consent for children's health care initially evolved through the common law, ${ }^{105}$ the doctrine of parental consent assumed constitutional dimensions in the latter part of the twentieth century. ${ }^{106}$ This important line of cases had its inception in the 1920s, with Meyer v. Nebraska and Pierce v. Society of Sisters. ${ }^{107}$ These cases together establish that parental authority to exercise discretion in the upbringing of their children is an expression of liberty protected by the Due Process Clause of the Fourteenth Amendment. ${ }^{108}$

Investing parents with some measure of discretion in decisionmaking regarding their minor children's welfare recognizes the functional role of families in our society. Our social structure is premised upon the existence of family units, whose dependent children rely for support, nurturance, and

${ }^{104}$ See Parham v. J.R., 442 U.S. 584, 584-85 (1979); Bellotti v. Baird, 443 U.S. 622, 635-39 (1979)

${ }^{105}$ Under early common law, fathers had property-like interests in their children and their wives, which were associated with substantial legal control over those persons. It included, for example, fathers' entitlement to the wages earned by his minor children and disciplinary authority, including corporal punishment. See, e.g., Anne C. Dailey \& Laura A. Rosenbury, The New Law of the Child, 127 YALE L.J. 1448, 1457-58 (2017) (describing common-law property-based theory of parental control of children); Barbara Bennett Woodhouse, "Who Owns the Child?": Meyer and Pierce and the Child as Property, 33 WM. \& MARY L. REV. 995, 1045-46 (1992) (discussing common law rights of patriarchs to "enforce control over their households"). Parental authority for health care decisions specifically, however, also flows from tort law. See, e.g., Danny R. Veilleux, Annotation, Medical Practitioner's Liability for Treatment Given Child Without Parent's Consent, 67 A.L.R. 4th 511 § 2[a] (1989) (describing changing liability for treatment of minors without parental consent); Walter Wadlington, Medical Decision Making for and by Children: Tensions Between Parent, State, and Child, 1994 U. ILL. L. REV. 311, 314-16 (describing early development of doctrine of parental consent). Depending on the case facts, physicians' failure to secure the consent of a child's parent before treating the child can result in liability as a form of battery, or more commonly in recent decades, negligence. Veilleux, supra, at 517. Principles clarifying exceptions to the doctrine of parental consent that allow minors authority to consent, discussed infra Section II.B.2, not only facilitate minors' independent access to treatment, but also protect physicians from such liability when relying solely on the consent of the minor. Doriane Lambelet Coleman \& Philip M. Rosoff, The Legal Authority of Mature Minors to Consent to General Medical Treatment, 131 PEDIATRICs 786, 790 (2013).

${ }^{106}$ See Parham v. J.R., 442 U.S. 584, 620 (1979) (assuming a child has a liberty and due process right in their voluntary admittance to a mental institution but ultimately upholding the state of Georgia's procedures for admitting a child for treatment to a state mental hospital); Bellotti v. Baird, 442 U.S. 622, 651 (1979) (holding a state can require parental consent for a minor to obtain an abortion, but that there must be a judicial route for minors seeking an abortion without parental consent).

${ }^{107}$ Pierce v. Soc'y of Sisters, 268 U.S. 510, 534-35 (1925); Meyer v. Nebraska, 262 U.S. 390, 399 (1923).

${ }^{108}$ For a critical analysis of Meyer and Pierce as constitutionalizing a property-like notion of parental rights, see Woodhouse, supra note 105, at 997 (asserting that Meyer and Pierce "were animated, as well, by ... a conservative attachment to the patriarchal family, to a class-stratified society, and to a parent's private property rights in his children and their labor"). 
protection upon parents who have both the desire and capacity to act in their children's best interests. ${ }^{109}$ Parents in our society are charged with guarding their children's welfare and guiding their children's destiny. Allowing parents to carry out these duties in a manner consistent with their judgment and values serves a myriad of positive goals. Indeed, there are many justifications for a legal regime that protects parental authority over their children's welfare, including health care decisions. ${ }^{110}$ We highlight four here: (1) the family unit serves as a core building block within our social structure and is the institution best situated to care for, protect, and socialize children; (2) parental discretion in raising children is an important accompaniment to legal childrearing obligations; (3) parents are those persons typically most motivated, able, and best situated to make decisions in the best interests of their children; and (4) most minors have not yet achieved adult levels of maturation and must rely on adults to make important decisions for them.

The primacy of the family in American society provides the first rationale for protection of parental authority over children's welfare. The family, as a unit, has a special place in American society. It forms the "building blocks out of which the larger units of social organization are fashioned," $" 11$ and its social and economic stability and functionality are essential to the perpetuation of a healthy society. ${ }^{112}$ One component of the family's traditional role in society is the procreation, nurturance, and socialization of children. ${ }^{13}$ Modern conceptions of family view it as an institution uniquely suited to this role.

Major shifts in images of children and family occurred during the nineteenth and early twentieth centuries. ${ }^{114}$ For example, historian Michael

\footnotetext{
${ }^{109}$ Lois A. Weithorn, Envisioning Second-Order Change in America's Responses to Troubled and Troublesome Youth, 33 HoFSTRA L. REV. 1305, 1391-92 (2005) [hereinafter Weithorn, Envisioning].

${ }^{110} I d$. at 1391-98. Grounded initially in the legal and social authority of husbands and fathers over their wives and children, the purposes and nature of parental control over children has shifted substantially over the centuries. Michael Grossberg, Governing the HEARTH: LAW AND thE FAMILY IN NINETEENTH-CENTURY AMERICA 4-5 (1985).

111 John Demos, Images of the American Family, Then and Now, in CHANGing IMAGES OF THE FAMILY 43, 46 (Virginia Tufte \& Barbara Myerhoff eds., 1979). See also Moore v. City of East Cleveland, 431 U.S. 494, 503-04 (1977) ("It is through the family that we inculcate and pass down many of our most cherished values, moral and cultural.").

112 See Linda C. McClain, The Place of Families: Fostering Capacity, Equality, and RESPONSIBILITY 20-21 (2006) (analyzing how families instill values in future generations and help perpetuate social goods); Weithorn, Envisioning, supra note 109, at 1389-91 (describing theories of the family unit as the foundation of social, religious, educational, and political life).

113 "Families care for dependent children, prepare them for citizenship, and educate them to be productive members of society." Elizabeth S. Scott \& Robert E. Scott, From Contract to Status: Collaboration and the Evolution of Novel Family Relationships, 115 COLUM. L. REV. 293, 304 (2015).

${ }^{114}$ For example, sociologist Viviana A. Zelizer highlights children's roles as substantial economic assets to the family through their childhood labor prior to the shifts that occurred during the nineteenth and, even more sharply, twentieth century. VIVIANA A. ZELIZER, PRICING THE PRICELESS CHILD: THE
} 
Grossberg notes that during the nineteenth century, evolving perceptions of children as vulnerable and malleable, with each having his or her own unique "needs, talents, and characters," required the personalized and customized upbringing that only a family could provide. ${ }^{115}$ While the state (such as through public schools) shares in "molding the nation's young, ... youthful minds and bodies would develop properly only in a special, sheltered home under the watchful guidance of concerned ... parents." 116

Protecting some level of the family's autonomy in raising and socializing children from overly intrusive state regulation is also consistent with democratic ideology. In its rebuke to Oregon's legislature for regulating parental decisions regarding school choice with too heavy a hand, the Court asserted in Pierce that:

The fundamental theory of liberty . . . excludes any general power of the State to standardize its children .... The child is not the mere creature of the State; those who nurture him and direct his destiny have the right, coupled with the high duty, to recognize and prepare him for additional obligations. ${ }^{117}$

The Court's opinion implies that vesting considerable discretion in parents not only protects against governmental overreaching and excessive intrusion in family matters, but also guards other substantive liberties expressed within the family (such as political ideology and religious beliefs). Family autonomy, in turn, is viewed as fostering pluralism and diversity, which reinvigorates our democracy. Thus, constitutional protection for parental decisional authority over their minor children serves important social goals unrelated to individual children's needs.

A second, and corollary, argument for giving parents some degree of freedom in the ways in which they raise their children relates to the heavy burden parents assume in raising children. Empowering parents with the authority to raise children the way they see fit, albeit consistent with certain minimal state-imposed limits, may be viewed as a form of reciprocity for satisfying the legally enforceable duties of parenthood. ${ }^{118}$ In this, "[t]he exchange view of parenthood[,] . . . [p]arents have rights that create obligations and obligations that create rights. Within this circular, self-reinforcing cycle of exchange, rights are emphasized, strengthened by their justification in obligation." "119 Katharine Bartlett has reframed this concept by focusing on the relationship components of parents'

Changing Social VALUE OF CHILDREN 5, 56-57 (1985). Children's value to their parents morphed from that of an "instrumental or fiscal" asset to "exclusively emotional and affective." Id. at 11.

${ }^{115}$ GROSSBERG, supra note 110 , at 8.

${ }^{116} \mathrm{Id}$.

${ }^{117}$ Pierce v. Soc'y of Sisters, 268 U.S. 510, 535 (1925).

${ }^{118}$ Elizabeth S. Scott \& Robert E. Scott, Parents as Fiduciaries, 81 VA. L. REV. 2401, 2440 (1995).

${ }^{119}$ Katharine T. Bartlett, Re-Expressing Parenthood, 98 YALE L.J. 293, 298 (1988). 
responsibilities to children. "Responsibility describes a certain type of connection that persons may experience in their relationships with one another . . . . Responsibility, in other words, is a self-enlarging, open-ended commitment on behalf of another." "She suggests that providing parents with a wide berth in the manner in which they carry out their parental responsibilities constitutes a logical and natural reliance on the commitment parents have made to doing their best for their children. ${ }^{121}$

Scott and Scott, by contrast, analogize the role of parents to those of fiduciaries: "On this dimension, parental authority over the relationship with children is offered as the quid pro quo for satisfactory performance . . . . Recognition of these parental claims in some form is an important inducement to encourage investment in children's welfare." ${ }^{122}$ Both approaches recognize that there is an important connection between the legal responsibilities and obligations that parents shoulder in raising children and the constitutionally protected authority to carry out those duties in a manner consistent with one's personal judgment and values.

A third rationale justifying parental authority in children's upbringing, including in health care, is that American law presumes that parents are motivated to make, and are capable of making, decisions in their children's best interests. ${ }^{123}$ Chief Justice Burger, writing for the majority in Parham v. $J . R$, a case addressing parental authority for decisions to place their minor children in mental hospitals without judicial oversight, opined that the "natural bonds of affection lead parents to act in the best interests of their children." 124 While acknowledging that this presumption may not always hold, as in the case of child abuse or neglect, the Court concluded that the existence of exceptions "is hardly a reason to discard wholesale those pages of human experience that teach that parents generally do act in the child's best interests." 125 Justice Burger's assertion regarding the proclivities of most parents conforms with the dominant view in society that parents try to do the best they can by and for their children. Indeed, those of us who are fortunate enough to be parents can attest to the powerful emotional forces that lead most of us to dedicate ourselves to promoting what we believe is in our children's best interests. As Barbara Bennett Woodhouse observes with the example of a parent who runs into a burning building to rescue his or her child, parental love and protective instincts can motivate a parent to

${ }^{120} \mathrm{Id}$. at 299.

${ }^{121} I d$. at $299-300$.

${ }^{122}$ Scott \& Scott, supra note 118 , at 2440 .

${ }^{123}$ Goldstein, Freud, and Solnit assert as well that it is in children's best interests to have autonomous parents whose discretion in decisionmaking is protected against most potential or actual forms of state intrusion. JOSEPH GOLDSTEIN ET AL., BEFORE THE BEST INTERESTS OF THE CHILD 4-5 (1973).

${ }^{124}$ Parham v. J.R., 442 U.S. 584, 602 (1979)

${ }^{125} \mathrm{Id}$. at $602-03$. 
place herself or himself at great personal risk — without a second thoughtto further a child's well-being. ${ }^{126}$

Embedded in the presumption that parents act in their children's best interests is the notion that the interests of parents and children typically align or are coextensive. Thus, there is a corollary presumption that there is an "identity of interests" between parent and child. ${ }^{127}$ The parent is presumed to speak on the child's behalf. Thus, to the extent that there is evidence that the interests of a parent and minor are not aligned, the appropriateness of relying on parental decisionmaking is questionable. As Chief Justice Burger acknowledged, sometimes the evidence is clear that parental conduct and choices harm or endanger minor children, providing a strong basis to rebut the presumption that parents are acting in their children's best interests. ${ }^{128}$ Yet, there may be situations that fall short of documented child abuse or neglect that reveal a conflict, rather than identity, of interests between parents and children. ${ }^{129}$

A fourth rationale for parental decisional authority over their minor children recognizes that, in light of the physiological, psychological, and economic dependence of children, someone must play the roles alluded to by Grossberg. Most children have not achieved adult levels of maturity in a range of areas of functioning. They depend upon adults to meet their essential needs. ${ }^{130}$ Although the age at which children typically reach species-typical milestones characterizing adult levels of functioning differs with the particular skills and capacities in question, and from individual to individual, it is undeniable that most children need adult care, protection, and nurturance to survive and to have the best opportunity to thrive. ${ }^{131}$

126 Barbara Bennett Woodhouse, Of Babies, Bonding, and Burning Buildings: Discerning Parenthood in Irrational Action, 81 VA. L. REV. 2493, 2496-97 (1995).

127 J. Shoshanna Ehrlich, Shifting Boundaries: Abortion, Criminal Culpability and the Indeterminate Legal Status of Adolescents, 18 WIS. WOMEN's L.J.77, 86-87 (2003); Amy L. Komoroski, Stimulant Drug Therapy for Hyperactive Children: Adjudicating Disputes Between Parents and Educators, 11 B.U. PUB. INT. L.J. 97, 107 (2001). But see Hazel Glenn Beh \& Milton Diamond, David Reimer's Legacy: Limiting Parental Discretion, 12 CARdozo J.L. \& Gender 5, 30 (2005) (discussing the concept of parent-child identity versus conflict of interests in the context of surgical intervention for children with ambiguous genitalia); Hillary Rodham, Children Under the Law, 43 HARV. EDUC. REV. 487, 507 (1973) (proposing that the traditional presumption of identity of interests between a parent and child should be rejected when the child's interests are "demonstrably independent" from those of the parents).

${ }^{128}$ See, e.g., CAL. Welf. \& INST. CODE § 300(b)(1) (West, Westlaw through 2019 Reg. Sess. ch. 524) (allowing finding of neglect if substantial risk of serious harm due to parents' failure to obtain needed medical treatment for child).

${ }^{129}$ See the discussion of statutory exceptions to the doctrine of parental consent infra Section II.B.2.iii.

${ }^{130}$ Lois A. Weithorn, A Constitutional Jurisprudence of Children's Vulnerability, 69 HASTINGS L.J. 179, 226-27 (2017) [hereinafter Weithorn, Children's Vulnerability].

${ }^{131} \mathrm{Id}$. at 227. 
One component of children's immature physiological and psychological status is their not-yet-fully-developed cognitive and socioemotional decisional capabilities. The law generally views children as incapable of acting in their own best interests and treats their incompetence in making most personal decisions of legal import, including health care decisions, as presumptive. ${ }^{132}$ In Parham, the majority stated that "[m]ost children, even in adolescence, simply are not able to make sound judgments concerning many decisions, including their need for medical care or treatment." 133 Indeed, the Court has distinguished the constitutional status of children and adults based, in part, on children's perceived "inability to make critical decisions in an informed and mature manner." ${ }^{134}$ For the reasons asserted above, parents are typically the logical and convenient first choice to serve as proxy decisionmakers for their children. ${ }^{135}$

Yet, as many have observed, de facto or actual competence for a particular legal purpose may not track the bright-line age-based, and to some extent arbitrary, division between minority and majority that serves as the default for delineation of legal rights and duties. ${ }^{136}$ In fact, those "pages of human experience" referred to by Chief Justice Burger and a growing body of empirical research tell us that-depending upon the particular skills and capacities relevant to the law-minors may satisfy legal standards of competence at ages younger or older than the legal age of majority. ${ }^{137}$ Thus,

${ }^{132}$ B. Jessie Hill, Medical Decision Making by and on Behalf of Adolescents: Reconsidering First Principles, 15 J. Health CARE L. \& POL'Y 37, 40-41 (2012); Jennifer L. Rosato, Let's Get Real: Quilting a Principled Approach to Adolescent Empowerment in Health Care Decision-Making, 51 DePaul L. ReV. 769, 771-72 (2002); Elizabeth S. Scott, The Legal Construction of Adolescence, 29 Hofstra L. REV. 547, 550-51 (2000). See Laurence Steinberg, Does Recent Research on Adolescent Brain Development Inform the Mature Minor Doctrine?, 38 J. MED. \& PHIL. 256, 256 (2013) (citing constitutional jurisprudence holding that minors' immaturity mitigates their criminal culpability).

${ }^{133}$ Parham v. J.R., 442 U.S. 584, 603 (1979).

${ }^{134}$ Bellotti v. Baird, 443 U.S. 622, 634 (1979).

${ }^{135}$ The Court in Parham indicated that "[p]arents can and must make ... judgments [as to children's need for medical care or treatment]." Parham, 442 U.S. at 603.

${ }^{136}$ Thomas Grisso \& Linda Vierling, Minors' Consent to Treatment: A Developmental Perspective, 9 PROF. PSYCHOL. 412, 415-16 (1978); Rodham, supra note 127, at 488-89; Lois A. Weithorn, Developmental Factors and Competence to Make Informed Treatment Decisions, 5 CHILD \& YOUTH SERVICES 85, 86 (1982) [hereinafter Weithorn, Developmental Factors].

${ }^{137}$ Lois A. Weithorn, Children's Capacities in Legal Contexts, in Children, Mental Health, AND THE LAW 25, 37-38 (N. Dickon Reppucci et al. eds., 1984); Grisso \& Vierling, supra note 136, at 423; Grace Icenogle et al., Adolescents' Cognitive Capacity Reaches Adult Levels Prior to Their Psychosocial Maturity: Evidence for a "Maturity Gap" in a Multinational, Cross-Sectional Sample, 43 LAW \& Hum. Behav. 69, 79 (2019); Laurence Steinberg et al., Are Adolescents Less Mature than Adults?: Minors' Access to Abortion, the Juvenile Death Penalty, and the Alleged APA "Flip-Flop", 64 AM. PSYCHOL. 583, 586-87 (2009); Weithorn, Developmental Factors, supra note 136, at 95-96; Lois A. Weithorn \& Susan B. Campbell, The Competency of Children and Adolescents to Make Informed Treatment Decisions, 53 CHILD DEV. 1589, 1595 (1982). The capacities of minors to satisfy legal standards of competence to consent to childhood vaccinations independent of their parents is discussed below. See infra Parts III.B.2-III.B.3. 
there are circumstances in which the presumption that minors are incompetent to make important life decisions for themselves, including certain medical choices, is not supported by the available evidence. ${ }^{138}$ While minors' competence to make health care decisions may not serve as an independent basis for providing minors with generalized decisional authority in place of their parents, it may operate to provide the alternative mechanism for certain health care decisions if, for one reason or another, a reliance on parental consent alone would not achieve important interests. ${ }^{139}$

\section{B. Exceptions to the Doctrine of Parental Consent}

Parental authority over the lives of their children is neither boundless nor unregulated. While deference to parents remains the default in the context of children's health care decisionmaking, judicial and legislative balancing of competing interests involving constitutional and policy considerations created a complex web of exceptions to parental control over minor children's health care decisions.

\section{Underlying Constitutional and Policy Frameworks}

The exceptions can be best understood within the context of certain constitutional and policy frameworks that allow for analysis of competing interests among parents, the state, and children. As noted above, parents have a constitutionally protected liberty interest in exercising discretion in decisionmaking regarding their children's welfare, including authority over decisions for minor children's health care. This interest has been classified as fundamental, although this classification does not always result in the application of strict scrutiny to challenged statutes and regulations. Instead, the Court appears to apply context-specific modes of analysis, frequently falling back on balancing tests. ${ }^{140}$

Not surprisingly, exceptions to the doctrine of parental consent exist in circumstances where courts or legislatures determine that the interests of the state or the children are weightier than those of the parents. Minors' own

${ }^{138}$ See infra Parts III.B.2-III.B.3.

${ }^{139}$ See infra notes $237-50$ and accompanying text.

${ }^{140}$ Despite its status as a "fundamental right," strict scrutiny review is not always required of state regulations challenged as interfering with that authority. Reiss \& Weithorn, Responding to the Childhood Vaccination Crisis, supra note 7, at 908-10. While at times the Court does apply strict scrutiny to challenged laws, it often applies alternative modes of analysis, such as balancing tests, or other context-specific standards of review customized to the particular issues and constellation of parties and interests. Id. See also Margaret Ryznar, A Curious Parental Right, 71 SMU L. REV. 127, 128 (2018) (observing that the U.S. Supreme Court has "not articulated a consistent level of scrutiny for judicial review of restrictions on" parental decisional rights regarding the care, custody, and control of their minor children). That said, constitutional scholars have concluded that mandatory vaccination laws, even if providing no vaccine exemptions other than those that are medically necessary, satisfy strict scrutiny. Erwin Chemerinsky \& Michele Goodwin, Compulsory Vaccination Laws Are Constitutional, 110 Nw. U. L. REV. 589, 614 (2016). 
constitutional rights may compete with parental claims. Policy considerations, such as those relating to preserving life or promoting health may override parental rights. In some instances, the justifications and rationales underlying the doctrine of parental consent ${ }^{141}$ —each of which might be viewed as an assumption about the functioning of the family, parents, or children-may simply not hold true. In these circumstances, courts or legislatures may fashion exceptions to the doctrine of parental consent, that is, alternative decisionmaking structures to promote children's best interests. Throughout the remainder of this Article, when discussing legal exceptions to the doctrine of parental consent, we reference one or another of these constitutional, policy, or practical bases for creating such exceptions.

The Court often engages in a dyadic balance of parental rights of decisional autonomy and the state's interests (parens patriae and police power) in children's welfare. The parens patriae power refers to the state's paternalistic authority to regulate the lives of individuals to protect and promote those persons' own welfare. ${ }^{142}$ Parens patriae regulations are typically aimed at those persons, such as children or other vulnerable or dependent groups, viewed as unable to protect, care, or decide wisely for themselves, thus triggering a higher level of protection from the state. The police power, by contrast, seeks to regulate the conduct of individuals in order to promote the general welfare and promote the interests of the community or society as a whole. ${ }^{143}$ A powerful statement of the state's police power authority appears in the seminal mandatory vaccination case, Jacobson v. Massachusetts, in which the U.S. Supreme Court emphasized the "social compact" between the state and its citizens, requiring each of us to acquiesce to policies that advance "the common good" (that is, the safety and protection of the populace), even when such acquiescence restricts our liberty. ${ }^{144}$

${ }^{141}$ The four sets of rationales, as laid out above, are as follows: (1) the family unit serves as a core building block within our social structure, the institution best situated to care for, protect, and socialize children; (2) parental discretion in raising children is an important accompaniment to legal childrearing obligations; (3) parents are those persons typically most motivated, able, and best situated to make decisions in the best interests of their children; and (4) most minors have not yet achieved adult levels of maturation and must rely on adults to make important decisions for them. See supra notes 111-35 and accompanying text.

142 'Parens patriae, literally 'parent of the country,' is the government's power and responsibility, beyond its police power over all citizens, to protect, care for, and control citizens who cannot take care of themselves . . . ." Natalie Loder Clark, Parens Patriae and a Modest Proposal for the Twenty-first Century: Legal Philosophy and a New Look at Children's Welfare, 6 MiCH. J. GENDER \& L. 381, 382 (2000).

${ }^{143}$ Weithorn, Envisioning, supra note 109, at 1402-03. The state's police power interest justifies regulations that seek to promote the safety, health, and prosperity of society as a whole. See, e.g., Developments in the Law: The Constitution and the Family, 93 HARV. L. REV. 1156, 1214 (1980) (discussing the state's parens patriae and police power interests).

${ }^{144}$ Jacobson v. Massachusetts, 197 U.S. 11, 27 (1905). 
The state has substantially broader authority to regulate the lives of children than it does the lives of adults, primarily because government's parens patriae and police power interests are weightier relative to children than to adults. ${ }^{145}$ State involvement in children's lives provides a classic expression of its parens patriae concerns for a subgroup of its citizens. Unlike adults, children are presumed to be incompetent under the law and therefore incapable of acting effectively on their own behalves or safeguarding their own interests. ${ }^{146}$ The Court has identified, however, a second factor that also fuels the state's paternalistic concern. Children are also thought to be more vulnerable than adults. ${ }^{147}$ Weithorn provides an analysis of the construct of vulnerability and its subtypes, as relied upon by the Court in justifying the differential legal treatment of adults and children. ${ }^{148}$ In general, persons who are perceived to be vulnerable are thought to be at greater risk for, or more susceptible to, deleterious consequences as a result of certain experiences, influences, or exposures than are others. ${ }^{149}$ Children as vulnerable persons are in greater need of protection by those concerned with their best interests than are those not seen as vulnerable. The law's presumption of children's incompetence and conceptions of children's vulnerability frequently trigger the state's watchful eye and greater state involvement in children's than in adults' lives, justified by its parens patriae interests.

The state's police power interests regarding children are also broader when compared with those justifying intervention in the lives of adults. Weithorn has identified two subtypes of police power interests relevant to state regulation of children: those generally related to public safety and those generally related to children's socialization. ${ }^{150}$ The first category is analogous to the police power interests the state maintains relative to all its inhabitants. It seeks to protect those within its borders from harm by restraining dangerous conduct and conditions. ${ }^{151}$ Thus, a wide range of policies, such as health codes, environmental regulations, criminal laws, and more, are in place to constrain actions and activities that threaten the welfare

${ }^{145}$ Prince v. Massachusetts, 321 U.S. 158, 168 (1944).

${ }^{146}$ See, e.g., Parham v. J.R., 442 U.S. 584, 623 (1979) (indicating that minors under the age of seventeen are "presumptively incapable of making [a] voluntary commitment decision for [themselves]"); Bellotti v. Baird, 443 U.S. 622, 635 (1979) (asserting that "during the formative years of childhood and adolescence, minors often lack the experience, perspective, and judgment to recognize and avoid choices that could be detrimental to them").

${ }^{147}$ Bellotti, 443 U.S. at 634 (referring to children's "peculiar vulnerability" as one of the three reasons justifying the treatment of children as constitutionally different from adults).

${ }^{148}$ Weithorn, Children's Vulnerability, supra note 130, at 187-88.

${ }^{149} \mathrm{Id}$. at 190 .

${ }^{150}$ Weithorn, Envisioning, supra note 109, at 1404

${ }^{151} I d$. at 235. 
of others. ${ }^{152}$ Notably, the most important case reinforcing the state's constitutional authority under its police power relative to public healthJacobson v. Massachusetts ${ }^{153}$ — concerned mandatory vaccinations. ${ }^{154}$ The Court acknowledged that the liberty interest claimed by Jacobson (an adult), who sought to repel the state's mandate that he be inoculated against smallpox or pay a five dollar fine, was the "greatest of all rights." "155 Yet, it held that this right is not absolute, and must give way in instances such as that presented in this case, where the public health was at risk from a life-threatening contagious disease: "[T] he police power of a State must be held to embrace, at least, such reasonable regulations established directly by legislative enactment as will protect the public health and the public safety." $"{ }^{156}$ As we have indicated elsewhere, Jacobson remains good law over a century after its writing and has been repeatedly cited with approval by the Court. ${ }^{157}$

The state's other primary police power interest relative to children concerns its goal of fostering children's socialization in order to promote their development into the well-adjusted adults who contribute constructively to society. The Court has noted that, if children do not mature into such adults, our society cannot prosper: "A democratic society rests, for its continuance, upon the healthy, well-rounded growth of young people into full maturity as citizens, with all that implies."158 Frequently, the state's socialization-oriented police power interests relative to children converge with its parens patriae interests. In other words, state regulations viewed as promoting a child's own best interests typically also contribute to children's positive socialization. Two of the best-known regulatory structures justified by both the parens patriae and police power authorities are compulsory

${ }^{152}$ See Jorge E. Galva et al., Public Health Strategy and the Police Powers of the State, 120 PUB. HEALTH REP. 20, 23-24 (2005) (discussing the police power as a way to restrict harmful conduct and promote the public health).

${ }^{153}$ Jacobson v. Massachusetts, 197 U.S. 11, 11-12 (1905).

${ }^{154}$ For a discussion of the case and its implications for the development of the doctrine relating to the police power and health care, see Reiss \& Weithorn, Responding to the Childhood Vaccination Crisis, supra note 7, at 894-901.

${ }^{155}$ Jacobson, 197 U.S. at 27.

${ }^{156} \mathrm{Id}$. at 25

${ }^{157}$ Reiss \& Weithorn, Responding to the Childhood Vaccination Crisis, supra note 7, at 898-901. We observed:

Although one can speculate that Jacobson might be decided differently today, to date no decisions have expressly undercut its authority. To the contrary, Jacobson has been cited with approval by the U.S. Supreme Court dozens of times, including in recent decades, and by other federal and state courts several hundred times. The general principles set forth in Jacobson are sound and well-established.

Id. at 901 (footnote omitted).

${ }^{158}$ Prince v. Massachusetts, 321 U.S. 158, 168 (1944). 
education laws and prohibitions on child labor. ${ }^{159}$ Mandating education and restricting children's participation in the labor force are seen as promoting children's best interests. ${ }^{160}$ They require children to spend most of their waking hours in settings for the purpose of developing the fundamental skills the children will need to become capable adults. They also restrict children's involvement in settings where they might be injured, exploited, or otherwise harmed. The laws that promote these parens patriae objectives are also deemed to achieve police power goals by preparing children for their future involvement in society. ${ }^{161}$ Compulsory education laws are expected to increase the likelihood that children will contribute socially, economically, and politically ${ }^{162}$ once reaching adulthood. Child labor prohibitions not only free up the child to attend school, but are designed to protect children from dangerous and corrupting influences, such as injuries or other experiences that may undercut their development into self-sufficient and contributing adult members of society. ${ }^{163}$

Thus, although parents are empowered to serve as those persons with day-to-day responsibility for nurturing and supporting children's positive development, government continues to play a significant role in the formative process. While Meyer and Pierce may have clarified that the Constitution protects parental choice in educational decisions, these choices must still satisfy the state's minimal standards. Indeed, in Wisconsin v. Yoder, a 1972 case allowing Amish parents of three teenagers to withdraw them from public school a year or two (depending on the child) before reaching the state-defined minimum age for school exit, the Court made clear that its acquiescence was due to consideration of the public school education the children had already received together with the Amish families' intention to continue the children's education by preparing them for useful occupations within their community. ${ }^{164}$ The case is often viewed as creating the template for home-schooling laws, which do not allow

${ }^{159}$ See Weithorn, Envisioning, supra note 109, at 235-36 (listing compulsory education and child labor productions following the introduction of parens patriae and police power).

${ }^{160} I d$. at 235 .

${ }^{161} \mathrm{Id}$.

${ }^{162}$ See Plyler v. Doe, 457 U.S. 202, 221 (1982) (“[E]ducation provides the basic tools by which individuals might lead economically productive lives to the benefit of us all ... [and] has a fundamental role in maintaining the fabric of our society.”); Abington Sch. Dist. v. Schempp, 374 U.S. 203, 230 (1963) (Brennan, J., concurring) (regarding "the public schools as a most vital civic institution for the preservation of a democratic system of government"); Elizabeth Lamura, Our Children, Ourselves: Ensuring the Education of America's At-Risk Youth, 31 BufF. PUB. INT. L.J. 117, 117 (2013) ("Education is essential, not only to each individual child, but to the nation as a whole.").

${ }^{163}$ See Prince, 321 U.S. at 168-69 (referring to "the crippling effects of child employment" and stating that "legislation appropriately designed to reach such evils is within the state's police power, whether against the parents [sic] claim to control of the child or one that religious scruples dictate contrary action").

${ }^{164}$ Wisconsin v. Yoder, 406 U.S. 205, 235 (1972). 
wholesale exemptions from educational mandates, but require parents to satisfy minimum standards under state regulations. ${ }^{165}$

In Prince v. Massachusetts, a case in which the Court upheld a state child labor regulation as applied to a Jehovah's Witness who allowed her ward to sell religious newspapers in public, it stated: "[N]either rights of religion nor rights of parenthood are beyond limitation. Acting to guard the general interest in youth's well-being, the state as parens patriae may restrict the parent's control . ..."166 Relative to the police power, the Court reinforced that "the family itself is not beyond regulation in the public interest." 167 And, in dicta that zeros in on the issue that is the focus of this Article, citing conjoined police power and parens patriae concerns, the Court indicated that parental rights do "not include liberty to expose the community or the child to communicable disease or the latter to ill health or death." 168

Indeed, although deference to parental health care choices for their children is the default under our legal system, parental discretion is not unlimited, and parental choices may be overridden where parents' decisions are deemed to endanger their children's welfare ${ }^{169}$ or the public's health. ${ }^{170}$ When a health care intervention is necessary to serve both the parens patriae and police power interests, as in the case of preventing the spread of a contagious disease that endangers the health of the child to be immunized

${ }^{165}$ David M. Smolin, State Regulation of Private Education: Ohio Law in the Shadow of the United States Supreme Court Decisions, 54 U. CIN. L. REV. 1003, 1012-13 (1986). See also Louis A. Greenfield, Religious Home-Schools: That's Not a Monkey on Your Back, It's a Compelling State Interest, 9 RUTGERS J. L. \& RELIGION 1, 5 (2007) ("One of the major impacts of Yoder is essentially the showing that home-schooling is valid. However, ... home-schooling is not without its restrictions.").

${ }^{166}$ Prince, 321 U.S. at 166-67 ("[T] he state has a wide range of power for limiting parental freedom and authority in things affecting the child's welfare ....").

${ }^{167} \mathrm{Id}$. at 166 .

${ }^{168} I d$. at $166-67$.

${ }^{169}$ See, e.g., Newmark v. Williams, 588 A.2d 1108, 1110 (Del. 1991) (stating that a parent's right to make important decisions for their children is not absolute); Custody of a Minor, 379 N.E.2d 1053, 1056 (Mass. 1978) (overriding parents' decision to refuse chemotherapy treatment for their child with leukemia). State civil and criminal child maltreatment statutes stipulate that parents are obliged to provide their children with adequate medical care, and that failure to do so can result in a finding of medical neglect. See, e.g., CAL. WeLF. \& INST. CODE § 300(b)(1) (West, Westlaw through 2019 Reg. Sess. ch. 524) (stating that the juvenile court may determine a child is a dependent of the court if "the child has suffered, or there is a substantial risk that the child will suffer, serious harm or illness . . . by the willful or negligent failure of the parent or guardian to provide the child with adequate ... medical treatment"). For a summary and analysis of medical neglect laws, see SAMUEL M. DAVIS ET AL., CHILDREN IN THE LEGAL SYSTEM 573-618 (5th ed. 2014).

${ }^{170}$ See Garcia v. N.Y.C. Dep't of Health \& Mental Hygiene, 106 N.E.3d 1187, 1196 (N.Y. Ct. App. 2018) (upholding New York City Board of Health regulations mandating influenza vaccine for certain populations of students, stating that "the rules challenged here do not relate merely to a personal choice about an individual's own health but, rather, seek to ensure increased public safety and health for the citizenry by reducing the prevalence and spread of a contagious infectious disease within a particularly vulnerable population"); see also Brown v. Smith, 235 Cal. Rptr. 3d 218, 225 (Cal. Ct. App. 2018) (distinguishing Yoder as a situation which did not involve risks to the public's safety or welfare). 
and of the larger community, and the risk to the child from the immunization is extremely low, the case for overriding parental discretion is exceptionally strong. ${ }^{171}$ We have asserted elsewhere that the "current mandatory vaccination requirements for children are justified by a robust alliance of police power and parens patriae state concerns, which in the context of state regulation of children's lives confers breathtakingly broad authority to override parental decisionmaking" by requiring parents to vaccinate their children prior to school entry. ${ }^{172}$ One can analogize the convergence of the parens patriae and police power interests in the context of mandatory vaccination laws to the policies underlying compulsory education and child labor laws. ${ }^{173}$ This convergence of parens patriae and police power interests in the context of required childhood vaccinations distinguishes such medical interventions from the typical context in which parents retain substantial discretion in making health care decisions for their minor children (that is, when parens patriae interests alone are balanced against parental decisionmaking discretion). ${ }^{174}$ Given this convergence of interests, the analogy holds as well when considering our proposal to authorize older minors to access these interventions independently.

The constitutional framework discussed thus far presumes a dyadic balancing of interests between parents and the state and assumes that these two parties' interests in the child's welfare will yield a result that serves the child's best interests. Some commentators have challenged this model, critiquing the absence of the "child's voice," arguing that children's interests are not adequately represented when disputes are framed primarily or solely as contests between the parents and the state. ${ }^{175}$ Justice William O. Douglas

${ }^{171}$ See Chemerinsky \& Goodwin, supra note 140, at 610 (asserting that compulsory vaccination laws satisfy strict scrutiny).

${ }^{172}$ Reiss \& Weithorn, Responding to the Childhood Vaccination Crisis, supra note 7, at 912.

${ }^{173} \mathrm{Id}$. at 914 .

The primary prevention model driving today's mandatory vaccination of children can be closely analogized to the forward-looking goals of compulsory school attendance and restrictions on child labor. In these contexts, the policies, while seeking to provide benefits and prevent harms to children contemporaneous with the restrictions, also emphasize long-term benefits to the children and to society. Many of these benefits are to be realized when the children become adults. Thus, although child labor restrictions were motivated in part to protect children from the immediate risks of workplace dangers, concerns about children's overall socialization and availability for educational opportunities predominate in justifying these regulations in modern times.

Id.

${ }^{174}$ The Prince Court emphasized that parents' discretion in making decisions for their children is far narrower than the discretion adults can exercise when making decisions about their own lives: "Parents may be free to become martyrs themselves. But it does not follow they are free, in identical circumstances, to make martyrs of their children before they have reached the age of full and legal discretion when they can make that choice for themselves." Prince v. Massachusetts, 321 U.S. 158, 170 (1944).

175 See generally Leonard P. Edwards \& Inger J. Sagatun, Who Speaks for the Child?, 
famously challenged the Supreme Court majority's application of a dyadic balancing test in Wisconsin v. Yoder in a dissent asserting that the preferences of the three minor children, whose education was at the center of the case, should have figured into the Court's analysis. ${ }^{176}$ The Court began to engage, increasingly, in "triadic balancing" of the interests of parents, the state, and children as it recognized that minors have constitutionally cognizable interests and must be treated as constitutional actors in certain legal disputes. ${ }^{177}$

In the health care context, there are perhaps two separate sets of minors' interests at stake: (1) the interest in health and the preservation of one's life and (2) the interest in autonomous decisionmaking regarding one's health care, commensurate with their psychological capacities in certain circumstances.

\section{i. Children's Interest in Health and Preservation of Life}

According to one state supreme court: "All children indisputably have the right to enjoy a full and healthy life."178 Typically, in legal analyses, the state articulates the interests in children's good health and survival. The state asserts interests in preserving human life $\mathrm{e}^{179}$ and promoting the "healthy ... growth of young people into full maturity." 180 Yet, as those cases that perform triadic analyses of interests reveal, minors have strong independent interests in these goals as well. The independent interests of minors in continued life and good health are aligned with the state's interests in promoting minors' freedom from the harmful effects of life-threatening and

2 U. ChI. L. SCH. Roundtable 67 (1995); Donald H. Stone, The Dangers of Psychotropic Medication for Mentally Ill Children: Where Is the Child's Voice in Consenting to Medication? An Empirical Study, 23 TEMP. POL. \& C.R. L. REV. 121 (2013); Elaine E. Sutherland, Listening to the Child's Voice in the Family Setting: From Aspiration to Reality, 26 CHILD \& FAM. L. Q. 152 (2014). Recognizing the importance of independent consideration of the "child's voice" is but a first step. Debates often follow on the question of how to access children's independent interests. For example, there are multiple models that influence the ways in which children's interests are represented by lawyers in child protection cases. See, e.g., Josh Gupta-Kagan, Child Protection Law as an Independent Variable, 54 FAM. CT. REV. 398 , 403 (2016).

${ }^{176}$ Wisconsin v. Yoder, 406 U.S. 205, 241 (1972) (Douglas, J., dissenting). But see Emily Buss, What Does Frieda Yoder Believe?, 24 U. PA. J. Const. L. 53, 53 (1999) (questioning whether direct elicitation of children's views ultimately serves their interest in the context of free exercise rights).

${ }^{177}$ See, e.g., Bellotti v. Baird, 443 U.S. 622 (1979); Parham v. J.R., 442 U.S. 584 (1979). For discussion of a triadic framework recognizing children's developmental interests as distinct from interests of parents and the state, see William Galston, Parents, Government, and Children: Authority Over Education in a Pluralist Liberal Democracy, 5 LAW \& ETHICS HuM. RTs. 284 (2011). For a discussion of a "tripartite framework" that reconceptualizes the legal positions of the parties, see Anne C. Dailey \& Laura A. Rosenbury, The New Law of the Child, 127 YALE L.J. 1448, 1506 (2017).

${ }^{178}$ Newmark v. Williams, 588 A.2d 1108, 1116 (Del. 1991).

${ }^{179}$ Cruzan v. Dir., Mo. Dep't of Health, 497 U.S. 261, 282 (1990) (holding that the state may "assert an unqualified interest in the preservation of human life to be weighed against" other constitutionally protected interests); Washington v. Glucksberg, 521 U.S. 702, 735-36 (1997) (same).

${ }^{180}$ Prince v. Massachusetts, 321 U.S. 158, 168 (1944). 
other serious diseases. ${ }^{181}$ Indeed, state requirements for vaccination of children prior to school entry serves those ends. ${ }^{182}$

The United Nations Convention on the Rights of the Child, which was unanimously adopted by the U.N. General Assembly in 1989, devotes several articles to articulating children's human rights to "enjoyment of the highest attainable standard of health," and that "no child is deprived of his or her right of access to" health care services that include "preventive health care." ${ }^{183}$ Various scholars have concurred with the basic premise that access to adequate health care is a "human right," that is, something to which "we are entitled, simply by virtue of our humanity." 184 The poor performance of the United States in meeting the health care needs of its citizens, relative to other industrialized nations, has been the subject of much analysis, commentary, and criticism. ${ }^{185} \mathrm{We}$ do not revisit that discussion here. Rather,

${ }^{181}$ See, e.g., Custody of a Minor, 379 N.E.2d 1053, 1066 (Mass. 1978) (holding that a child whose parents rejected life-saving chemotherapy treatment had a "long-term interest in leading a normal, healthy life," converging with the state's strong interest in preserving human life, and justifying judicial order overriding parental refusal of highly effective treatment for their child's leukemia).

${ }^{182}$ For a detailed discussion of the ways in which the law can protect the interests of children in the context of vaccinations, see Dorit Rubinstein Reiss, Rights of the Unvaccinated Child, 73 STUD. L. POL. \& SOC'Y 73, 75 (2017).

${ }^{183}$ United Nations Convention on the Rights of the Child art. 24, Nov. 22, 1989, 1577 U.N.T.S. 3. See also id. art. 23 (recognizing rights of the disabled child to treatment); id. art. 25 (recognizing the right of a child in state custody for treatment of physical or mental health). The United States signed the Convention in 1995 but did not ratify it. See Convention on the Rights of the Child, UNITED NATIONS TREATY COLLECTION, https://treaties.un.org/Pages/ViewDetails.aspx?src=IND\&mtdsg_no=IV11\&chapter=4\&lang=en (last visited Mar. 16, 2020); What Is the Difference Between Signing, Ratification, and Accession of UN Treaties?, DAG HAMMARSKJÖLD LIBR. (Apr. 26, 2018), http://ask.un.org/faq/14594. While becoming a signatory indicates a nation's support in principle for the tenets set forth in a treaty, ratification indicates the nation's consent to be bound by the provisions. Although most federal and state laws in the United States are consistent with the Convention's provisions, some are not. In particular, the legality of corporal punishment and harsh sentencing policies affecting minors are cited as inconsistent with the Convention. Why Won't America Ratify the UN Convention on Children's Rights?, ECONOMIST (Oct. 7, 2013), https://www.economist.com/the-economistexplains/2013/10/06/why-wont-america-ratify-the-un-convention-on-childrens-rights.

${ }^{184}$ Mary Gerisch, Health Care as a Human Right, 43 HUM. RTs. 2, 2 (2018); see also George J. Annas \& Wendy K. Mariner, (Public) Health and Human Rights in Practice, 41 J. HEALTH POL. POL'Y \& L. 129, 136 (2016) (observing that the goals of the human rights and public health frameworks are aligned "to promote human flourishing"); Andrea S. Christopher \& Dominic Caruso, Promoting Health as a Human Right in the Post-ACA United States, 17 AMA J. ETHICS 958, 958 (2015) (citing the World Health Organization's constitutional declaration for "the enjoyment of the highest attainable standard of health" and noting that this "is one of the fundamental rights of every human being"); Benjamin Mason Meier et al., Human Rights in Public Health: Deepening Engagement at a Critical Time, 20 HEALTH \& HUM. RTS. J. 85, 86 (2018) (citing and endorsing the United Nations World Health Organization Constitution: "the enjoyment of the highest attainable standard of health is one of the fundamental rights of every human being"); Richard Smith et al., Shared Ethical Principles for Everybody in Health Care: A Working Draft from Tavistock Group, 318 BMJ 248, 250 (1999) (listing health care as a human right and an ethical principle that should govern healthcare systems).

${ }^{185}$ See, e.g., KAREN Davis ET AL., COMmOnWEalth Fund, Mirror, Mirror on the Wall: How the Performance of the U.S. Health Care System Compares Internationally (2014), https://www.commonwealthfund.org/sites/default/files/documents/_media_files_publications_fund_r 
we offer the less controversial and relatively straightforward proposition that, where there exists a cost-effective high benefit/low risk intervention that can protect a child from a serious and potentially life-threatening disease, unjustified barriers to that child's access to that intervention cannot be given legal authority. ${ }^{186}$ Thus, in our view, allowing parents to block children's receipt of medically recommended vaccinations unfairly risks those children's right to health and life. ${ }^{187}$ As such, any analysis of the interests of parents, children, and the state must recognize and weigh heavily children's independent interest in access to these easily available, cost-effective, health-promoting, and life-preserving interventions.

ii. Children's Autonomy Interest in Making Certain Health Care Decisions

There exist strong arguments that minors have a right to choose for themselves in some health care contexts. The foundation for that right varies across types of treatment as well in judicial analysis and scholarly commentary. For example, the U.S. Supreme Court has recognized that the Fourteenth Amendment liberty interest in controlling one's own procreative processes extends to minor females. ${ }^{188}$ While the Court has indicated that minors' rights are not identical to those of adults because of the balance of these rights with parental and state interests, ${ }^{189}$ minors clearly have a strong interest in exercising some measure of personal choice in the context of contraception, abortion, and prenatal health decisions. The Court has not spoken directly as to whether minors have an interest in bodily integrity that confers an autonomy interest in accessing or rejecting forms of treatment other than those relating to procreation. It has, however, in cases involving adults in other contexts, made clear that there exist rights to refuse

eport_2014_jun_1755_davis_mirror_mirror_2014.pdf(analyzing the performance of health care systems in eleven countries).

186 B. Jessie Hill, Constituting Children's Bodily Integrity, 64 DUKE L.J. 1295, 1356 (2015) (proposing a right to bodily integrity that, "[f]or younger minors, the right takes the form of a right to bodily security or protection - broadly, a right to have their best interests protected by the state against parents who fail to do so. For older, mature minors, the right becomes primarily an autonomy right to make their own decisions about their bodies when, and to the extent that, they are capable of doing so").

${ }^{187}$ Newmark v. Williams, 588 A.2d 1108, 1116 (Del. 1991) (“All children indisputably have the right to enjoy a full and healthy life."); (United Nations Convention on the Rights of the Child art. 23, Nov. 22, 1989, 1577 U.N.T.S. 3 (highlighting children's rights "to enjoy a full and decent life").

${ }^{188}$ See, e.g., Bellotti v. Baird, 443 U.S. 622, 647 (1979) (recognizing a minor female's constitutional liberty interest in controlling her own procreative decisions); Planned Parenthood of Central Missouri v. Danforth, 428 U.S. 52, 74 (1976) (same).

${ }^{189}$ Hodgson v. Minnesota, 497 U.S. 417, 418 (1990); H.L. v. Matheson, 450 U.S. 398, 422 (1981) (Stevens, J., concurring); Bellotti, 443 U.S. at 622-23. 
life-saving interventions, ${ }^{190}$ psychotropic medications, ${ }^{191}$ and commitment in a psychiatric hospital. ${ }^{192}$ Lower federal and state court decisions and state statutes have clarified that competent adults have an almost unqualified right to refuse treatment, ${ }^{193}$ except where doing so interferes with a weighty police power interest. ${ }^{194}$ And while our legal system does not confer an uncategorical and parallel right to receive treatment on all persons in all situations, including minors, certain policies seek to reduce barriers to treatment. ${ }^{195}$ Many scholars have argued that denial of available treatment to requesting minors solely due to the individual's minority unfairly deprives minors of certain inherent human rights, whether or not those rights are constitutionally protected. ${ }^{196}$

The concept of empowering minors to choose for themselves, commensurate with their capacities for making competent health care decisions, is not a new one. ${ }^{197}$ For example, many scholars have proposed

${ }^{190}$ See Washington v. Glucksberg, 521 U.S. 702, 720 (1997) (“In a long line of cases, we have held that, in addition to the specific freedoms protected by the Bill of Rights, the 'liberty' specially protected by the Due Process Clause includes [various rights to obtain or refuse certain treatments] . . . . We have also assumed, and strongly suggested, that the Due Process Clause protects the traditional right to refuse unwanted lifesaving medical treatment.”); Cruzan v. Dir., Mo. Dep't of Health, 497 U.S. 261, 262 (1990) ("For purposes of this case, it is assumed that a competent person would have a constitutionally protected right to refuse lifesaving hydration and nutrition.").

${ }^{191}$ See, e.g., Riggins v. Nevada, 504 U.S. 127, 133-34 (1992) (holding that there is a significant liberty interest in avoiding unwanted administration of antipsychotic drugs under the Due Process Clause of the Fourteenth Amendment); Washington v. Harper, 494 U.S. 210, 221-22 (1990) (same).

${ }^{192}$ See, e.g., O'Connor v. Donaldson, 422 U.S. 563, 575 (1975) (“'[T]here is . . . no constitutional basis for confining [mentally ill] persons involuntarily if they are dangerous to no one and can live safely in freedom.").

${ }^{193}$ See, e.g., Bouvia v. Superior Court, 225 Cal. Rptr. 297, 300 (Cal. Ct. App. 1986) (“'[A] patient has the right to refuse any medical treatment or medical service .... This right exists even if its exercise creates a 'life threatening condition.'”).

${ }^{194}$ Jacobson v. Massachusetts, 197 U.S. 11, 25 (1905) (“According to settled principles, the police power of a State must be held to embrace, at least, such reasonable regulations established directly by legislative enactment as will protect the public health and the public safety."); Workman v. Mingo Cty. Bd. of Educ., 419 F. App'x 348, 353-54 (4th Cir. 2011) ("[F]ollowing the reasoning of Jacobson and Prince, we conclude that the West Virginia statute requiring vaccinations as a condition of admission to school does not unconstitutionally infringe Workman's right to free exercise."); Boone v. Boozman, 217 F. Supp. 2d 938, 955-56 (E.D. Ark. 2002) (citing Cruzan, 497 U.S. at 279) ("[D]etermining that a person has a 'liberty interest' under the Due Process Clause does not end the inquiry; whether [an individual's] constitutional rights have been violated must be determined by balancing his liberty interests against the relevant state interests.").

${ }^{195}$ See, e.g., Patient Protection and Affordable Care Act, Pub. L. No. 111-148, 124 Stat. 119 (2010) (codified at 42 U.S.C. $§ 18116$ ) (prohibiting discrimination on the basis of race, color, national origin, sex, age, or disability in certain health programs or activities). See generally Children's Health Act of 2000, Pub. L. No. 106-310, 114 Stat. 1101 (codified as amended in scattered sections of 42 U.S.C., 21 U.S.C., 28 U.S.C., 18 U.S.C., and 25 U.S.C.).

${ }^{196}$ See supra notes $184-87$ and accompanying text.

${ }^{197}$ Although neuroscientific and psychological research have led scholars and the U.S. Supreme Court to conclude that adolescents' immaturity should preclude the imposition of the death penalty and other harsh criminal sentences on minors, researchers and other scholars distinguish questions of 
such a principle, although there are a range of views as to what the triggering circumstances and restrictions should be for reliance on minors' capacities as the bases for authorizing their independent health care decisionmaking. ${ }^{198}$ For all of the reasons discussed in Section II.A above, we do not propose a comprehensive shift in the default framework that authorizes parents to make health care decisions for their minor children. Yet, as the remainder of this Section demonstrates, there are circumstances in which exceptions to the default rule are warranted. Indeed, when it is determined that parents should not be sole decision makers in a particular health care context, for one reason or another, legislatures or courts must identify the alternative mechanism by which the health care choice can be made. ${ }^{199}$ Depending on the treatment context and other variables, such as the age and maturity of the children in question, authorizing minors to make autonomous decisions regarding their own health may be the most appropriate policy solution. ${ }^{200}$ In the specific context of the choice to vaccinate, we propose that as a supplementary and alternative consent mechanism, older minors be authorized to decide for themselves at the ages when their psychological capacities have matured sufficiently to enable them to satisfy the legal requirements for competent informed consent. As such, we bring our proposal in line with various exceptions to the doctrine of parental consent which operate in a manner analogous to our proposed exception. These exceptions and others are discussed below in Section II.B.2. In addition, our proposal is consistent with the relevant provisions of the first Restatement of the Children and the Law. In 2019, the American Law Institute adopted Section 19.01. ${ }^{201}$ Section 19.01 would authorize a minor "who is capable of

treatment decisionmaking capacity from those relevant to the criminal sentencing context. This juxtaposition is addressed further below in Section III.B.2.

${ }^{198}$ See, e.g., Vivian E. Hamilton, Immature Citizens and the State, 2010 BYU L. REV. 1055, 1136 39 (arguing that in the context of most medical decisions, minors should have decisionmaking authority consistent with their psychological capacities to decide competently); Rhonda Gay Hartman, Adolescent Autonomy: Clarifying an Ageless Conundrum, 51 HASTINGS L.J. 1265, 1269 (2000) (proposing that adolescent decisionmaking autonomy correspond to decisional ability in a range of areas of law); Hill, supra note 186, at 1356 (suggesting that "[f]or older, mature minors, the right becomes primarily an autonomy right to make their own decisions about their bodies when, and to the extent that, they are capable of doing so"); Rosato, supra note 132, at 804 (proposing varying levels of decisionmaking autonomy of minors depending on those minors' capacities and the nature and consequences of the particular health care decision); Neelam Chhikara, Note, Extending the Practice of Physician-Assisted Suicide to Competent Minors, 55 FAM. CT. REV. 430, 439 (2017) (proposing that physician aid in dying laws be extended to minors who meet the same capacity standards as adults, with no requirement of parental consent).

${ }^{199}$ Lois A. Weithorn, When Does a Minor's Legal Competence to Make Health Care Decisions Matter?, PEDIATRICS (forthcoming in Special Issue Defining Cases in Pediatric Bioethics: Future Insights from Past Controversies) (manuscript at 2) (on file with author) [hereinafter Weithorn, When Does a Minor's Legal Competence Matter?].

${ }^{200} \mathrm{Id}$.

201 Restatement of Children AND the Law $§ 19.01$ (AM. LAw InST., Tentative Draft Two 2019). 
giving informed consent to the proposed treatment" the authority to "consent to routine, beneficial medical treatment." $"$ "202 As we have demonstrated in Part I, ACIP-recommended vaccinations are indeed "routine" and "beneficial" medical interventions.

\section{The Exceptions}

We identify three sets of circumstances justifying exceptions to the doctrine of parental consent. These exceptions exist when legislatures or courts determine that, relative to a particular health care decision, one or more of the following conditions exists: (1) parents' interests in exercising authority over the child's health care are outweighed by the state's parens patriae or police power interests in the child's welfare and/or the child's independent (and possibly constitutionally protected) interests in health care decisional autonomy; (2) the presumption that parents are acting, are capable of acting, or are situated to act to promote their children's best interests relative to a health care decision does not accurately reflect the circumstances; and/or (3) the presumption that minors are incompetent to decide for themselves is not supported by the evidence. Importantly, though, the third condition is typically not the sole basis on which an exception is grounded. More commonly, the capacity of minors to decide for themselves becomes relevant only after constitutional or policy considerations lead to rejection or modification of the parental consent requirement. ${ }^{203}$ At that point, the capacities of minors to decide becomes a factor in determining what is the most appropriate alternative or supplementary decisional structure. Should minors be empowered to choose or should others (such as the court or a court-appointed guardian) be authorized to decide on the minor's behalf? We discuss below three primary alternative decisionmaking mechanisms: medical neglect proceedings, the mature minor doctrine, and treatment-specific statutory exceptions.

i. $\quad$ State Dependency Statutes: Case-by-Case Substitution of the State as Decisionmaker for the Child Under Medical Neglect Provisions

All fifty states and the District of Columbia have created legal mechanisms authorizing state intervention in the family in circumstances when parents are determined to fall below minimum standards of caregiving for their minor children. ${ }^{204}$ The state's parens patriae and police power

${ }^{202}$ Id.

${ }^{203}$ Weithorn, When Does a Minor's Legal Competence Matter?, supra note 199 (manuscript at 3).

204 Samuel M. Davis, Elizabeth S. Scott, Lois A. Weithorn \& WAlter Wadlington, ChILdREN IN THE LeGAL System 439-600 (6th ed. 2020); Lois A. Weithorn, Protecting Children from Exposure to Domestic Violence: The Use and Abuse of Child Maltreatment Statutes, 53 HASTINGS L.J. 1, 54 (2001) [hereinafter Weithorn, Protecting Children]; Weithorn, Envisioning, supra note 109, at 1323-24; see generally ChILD Welfare InFO. GATEWAY, DeP'T OF HEALTH \& Human SERVS., 
interests in protecting children from harm and risk of harm permit this intrusion into the family. The procedures and substantive standards delineating dependency system intervention must meet constitutional requirements. ${ }^{205}$ The legal framework is grounded on a model that requires individual case-by-case judicial findings of abuse or neglect prior to state substitution as decision maker on any of a wide range of childrearing matters, including health care decisions. ${ }^{206}$ If the court finds that there is sufficient evidence of abuse or neglect for it to assume jurisdiction over the child, the statutes confer on the state broad authority to regulate the child's life and to supervise the parents' activities relative to the child. ${ }^{207}$ The investigations, proceedings, and interventions are highly intrusive in the family's functioning and are premised on a finding of parental unfitness. ${ }^{208}$ As such, this type of intervention should be invoked only when necessary to protect the child from serious harm, where other, less intrusive legal strategies have not been, or are unlikely to be, effective. Such interventions are most appropriate when parental failure to meet children's health care needs is but one aspect of a more pervasive pattern of a failure to meet minimum caregiving standards or where ongoing state supervision of, and intervention in, parenting appears necessary to protect the child. When the only aspect of parenting that is endangering the child is the failure to immunize children from vaccine-preventable diseases, such an option should be viewed as an intervention of last resort and a preference given to less intrusive options. ${ }^{209}$

DEFINITIONS OF CHILD ABUSE AND NEGLECT (2019), https://www.childwelfare.gov/pubPDFs/ define.pdf (describing laws that define child abuse and neglect).

${ }^{205}$ Roe v. Conn, 417 F. Supp. 769, 778 (M.D. Ala. 1969); DAviS ET AL., supra note 204, at 52231; Weithorn, Protecting Children, supra note 204, at 63-64.

${ }^{206}$ DAVIS ET AL., supra note 204, at 573-618; Martha Minow, Beyond State Intervention in the Family: For Baby Jane Doe, 18 U. Mich. J.L. REFORM 933, 937 (1985); Weithorn, Protecting Children, supra note 204 , at $12-13$.

${ }^{207}$ See DAVIS ET AL., supra note 204, at 513-650.

${ }^{208}$ See Michael S. Wald, State Intervention on Behalf of "Neglected" Children: Standards for Removal of Children from Their Homes, Monitoring the Status of Children in Foster Care, and Termination of Parental Rights, 28 STAN. L. REV. 623, 625-27, 651 (1976).

${ }^{209}$ Certain provisions within dependency statutes permit the state to override parental health care decisions without finding parents neglectful, and thus permit a narrower and somewhat less intrusive manner of state intervention. See, e.g., FLA. STAT. ANN. § 39.01(35)(f) (West, Westlaw through 2019 First Regular Sess. of the 26th Legislature) (noting that in the context of a parental claim of religious exemption for the decision not to provide medical treatment for a child, "a parent or legal custodian who, by reason of the legitimate practice of religious beliefs, does not provide specified medical treatment for a child may not be considered abusive or neglectful for that reason alone, but such an exception does not ... [p]reclude a court from ordering, when the health of the child requires it, the provision of medical services by a physician"); IDAHO CODE ANN. § 16-1627(1)(b) (West, Westlaw through 2019 First Regular Sess. of the 65th Idaho Legislature 2019) (providing that "[a]t any time whether or not a child is under the authority of the court, the court may authorize medical or surgical care for a child when ... the life of the child would be greatly endangered without certain treatment and the parent, guardian or other custodian refuses or fails to consent"). Yet this approach requires the initiation of an adversarial dispute, 
A recent survey of state case law current through 2016 found nine cases in which parental failure to vaccinate was alleged to constitute a ground for medical neglect findings. ${ }^{210}$ Policy statements and analyses from committees of the American Academy of Pediatrics indicate that resorting to medical neglect proceedings is a disfavored response to parental non-vaccination of children within the medical community. ${ }^{211}$

ii. The "Mature Minor": Generic Standards in Statute and Case Law

The "mature minor" doctrine is a statutory or case law principle that allows minors authority to consent to or reject medical treatment under certain circumstances. ${ }^{212}$ As reviews of state statutes and applicable case law reveal, there is substantial variability across the states in terms of whether they have adopted any form of a "mature minor" rule and, if so, what the parameters are of that rule. ${ }^{213}$ In those states that have adopted some version of the principle and allow "mature minors" to make independent decisions about general medical care, the doctrine will generally apply if minors have reached a specified age or if judges or medical professionals determine them to be sufficiently "mature" to make their own medical decisions. ${ }^{214}$

In one of the first scholarly analyses of the doctrine, published in 1973 , the late Professor Walter Wadlington observed that the cases to which the rule had been applied generally involved older minors, that is, "[t]he particular minor was near majority (or at least in the range of 15 years of age upward), and was considered to have sufficient mental capacity to understand fully the nature and importance of the medical steps proposed"

pitting the state against the parents and requiring judicial resolution. In light of the intrusiveness into the family and the reliance on the state's already overburdened child protection resources, dependency system intervention is a disfavored mechanism for promoting vaccination policy when parents refuse to immunize their children.

${ }^{210}$ See Efthimios Parasidis \& Douglas J. Opel, Parental Refusal of Childhood Vaccines and Medical Neglect Laws, 107 AM. J. PuB. HeALth L. \& ETHICS 68, 68 (2017) (reporting nine cases from five states, with seven of the nine courts finding vaccine refusals to constitute medical neglect).

${ }^{211}$ See, e.g., Douglas S. Diekema \& Comm. on Bioethics, Responding to Parental Refusals of Immunization of Children, 115 PEDIATRICS 1428, 1430 (2005) (recommending an educational approach in response to parental refusal); Kathryn M. Edwards et al., Countering Vaccine Hesitancy, 138 PEDIATRICS e20162146, e11 (2016) (recommending, in addition, an educational approach in response to parental refusal).

212 ANGela Roddey Holder, Legal Issues in Pediatrics ANd Adolescent Medicine 133 42 (2d ed. 1985); Coleman \& Rosoff, supra note 15, at 787; Aviva L. Katz \& Sally A. Webb, Informed Consent in Decision-Making in Pediatric Practice, 138 PediatriCs e20161485, 4 (2016); Rosato, supra note 132, at 779; Elizabeth S. Scott, The Legal Construction of Adolescence, 29 HOFSTRA L. REV. 547, 567 (2000); Walter Wadlington, Minors and Health Care: The Age of Consent, 11 OsGOODE HALL L.J. $115,117(1973)$

${ }^{213}$ See, e.g., Coleman \& Rosoff, supra note 15, at 789-91 tbl.1 (detailing each state's provision for minors' consent).

${ }^{214} \mathrm{Id}$. at 789 . 
and the "medical procedures could be characterized by the courts as something less than 'major' or "serious' in nature." 115 In the decades since Professor Wadlington's seminal article, the generic form of the doctrine has not been widely adopted. ${ }^{216}$ Yet, the circumstances in which it has been applied have, in limited instances, expanded to those in which the treatment decision was both "major" and "serious," such as allowing minors with good prognoses to refuse lifesaving transfusions for religious reasons. ${ }^{217}$

States' initial adoptions of "mature minor" rules were a means to eliminate legal liability of health care professionals treating minors in circumstances when parents were unavailable or unwilling to consent. ${ }^{218}$ Yet, in the last several decades, some commentators in the fields of law and bioethics have asserted that minors should be authorized to make autonomous decisions regarding their own bodies if they are psychologically capable of making those decisions. ${ }^{219}$

Yet, the meaning of the term "maturity" in this context is not completely clear. $^{220}$ Some statutes and case law indicate or imply that the term "maturity" in this context is a synonym for health care decisionmaking capacity or competence. ${ }^{221}$ Treatment decisionmaking competence is

215 Wadlington, supra note 212 , at 119.

216 See, e.g., Coleman \& Rosoff, supra note 15, at 789 (indicating that " 14 states permit mature minors to consent to general medical treatment either in all or a range of restricted circumstances, and 3 states allow minors regardless of their age or maturity to consent to treatment in either all or limited circumstances"); Rosato, supra note 132, at 779-82 (observing that "[e]fforts to adopt a true mature minor doctrine have been limited" and discussing the limitations of the doctrine within those states that have statutes or recognized the doctrine in case law)

${ }^{217}$ See, e.g., In re E.G., 549 N.E.2d 322, 323, 328 (Ill. 1989) (allowing a seventeen-year-old who was determined by the court to be "mature," to refuse lifesaving blood transfusions on religious grounds, despite a predicted $80 \%$ likelihood of remission of leukemia with full treatment compliance); Douglas S. Diekema, Adolescent Refusal of Lifesaving Treatment: Are We Asking the Right Questions?, 22 Adolescent MeD. 213, 213 (2011) (discussing the case of Dennis Lindberg, a fourteen-year-old with leukemia who, like E.G., (1) objected to blood transfusions because of adherence to the tenets of the Jehovah's Witnesses; (2) had an excellent prognosis with treatment (predicted $70 \%$ chance of remission); and (3) was determined by the court to be mature enough to make the treatment decision independently); Weithorn, When Does a Minor's Legal Competence Matter?, supra note 199 (manuscript at 12-13).

${ }^{218}$ HOLDER, supra note 212, at 133-35; Coleman \& Rosoff, supra note 15, at 789.

219 See Hamilton, supra note 198, at 1136-39; Hartman, supra note 198, at 1269; Hill, supra note 186, at 1356; Rosato, supra note 132, at 804; Chhikara, supra note 198, at 439. The empirical research revealing that older adolescents can demonstrate adult-like levels of psychological competence to make treatment decisions is reviewed below. See infra notes 344-72 and accompanying text.

${ }^{220}$ Shawna Benston, Not of Minor Consequence?: Medical Decision-Making Autonomy and the Mature Minor Doctrine, 13 IND. HEALTH L. REV. 1, 3-8 (2016); Coleman \& Rosoff, supra note 15, at 789-90.

${ }^{221}$ See, e.g., ARK. CODE ANN. § 20-9-602(7) (West, Westlaw through 2019 Regular Sess. of the 92d Arkansas General Assembly) (authorizing "[a]ny unemancipated minor of sufficient intelligence to understand and appreciate the consequences of the proposed surgical or medical treatment or procedures" to consent to such medical or surgical care for himself or herself); IDAHO CODE ANN. § 39-4503 (West, Westlaw through 2019 First Regular Sess. of the 65th Idaho Legislature) (authorizing “[a]ny person ... who comprehends the need for, the nature of and the significant risks ordinarily inherent in any contemplated hospital ... or other health care . . . to consent thereto on his or her own behalf' (emphasis 
generally viewed as a cognitive standard, emphasizing the individuals' ability to understand, appreciate, and make decisions based on the treatment information disclosed by the health care practitioner. ${ }^{22}$ The standard competence inquiry is relatively circumscribed, focusing on capacity to make the specific decision at issue, without a broader inquiry into the patient's life functioning in other spheres. It is that laid out by the commentary to the 1979 Restatement of Torts (Second):

To be effective, the consent must be given by one who has the capacity to give it or by a person empowered to consent for him. If the person consenting is a child or one of deficient mental capacity, the consent may still be effective if he is capable of appreciating the nature, extent and probable consequences of the conduct consented to, although the consent of a parent, guardian or other person responsible is not obtained or is expressly refused. ${ }^{223}$

In 2019, the American Law Institute approved provisions of its new Restatement of Children and the Law, and adopted the treatment competence-oriented definition of a "mature minor" as one who is "capable of giving informed consent to the proposed treatment." 224 The treatment competence-oriented approach to maturity was articulated by the Maine Supreme Court in In re Swan, when noting that "[c]apacity exists when the minor has the ability of the average person to understand and weigh the risks and benefits." 225 The court then proceeded to cite the language of the Restatement of Torts commentary above. ${ }^{226}$ Yet, in some cases, judges have laid out two sets of standards: the more familiar treatment decisionmaking competence or capacity standard and a broader maturity standard. ${ }^{227}$ This broader maturity standard strives to capture a host of social, emotional, and psychological factors in addition to cognitive health care decisionmaking skills. For example, the Tennessee Supreme Court in Cardwell v. Bechtol considered:

the age, ability, experience, education, training, and degree of maturity or judgment obtained by the minor, [and] the conduct

\footnotetext{
added)); In re Swan, 569 A.2d 1202, 1205 (Me. 1990) (per curium) (holding that a minor has capacity to consent or refuse treatment when "the minor has the ability of the average person to understand and weigh the risks and benefits" and "if he is capable of appreciating the nature, extent, and probable consequences of the conduct consented to").

${ }^{222}$ See infra Section III.B.1.

${ }^{223}$ RESTATEMENT (SECOND) OF TORTS $\S 892 \mathrm{~A} \mathrm{cmt}$. b (AM. LAW INST. 1979).

${ }^{224}$ RESTATEMENT OF CHILDREN AND THE LAW §19.01 (AM. LAW INST., Tentative Draft Two 2019).

${ }^{225} 569$ A.2d 1202, 1205 (Me. 1990) (per curiam) (internal citation and quotation marks omitted).

${ }^{226}$ Id. (citing RESTATEMENT (SECOND) OF TORTS $\S 892 \mathrm{~A} \mathrm{cmt.} \mathrm{b} \mathrm{(AM.} \mathrm{LAW} \mathrm{INST.} \mathrm{1979)).}$

${ }^{227}$ See, e.g., Belcher v. Charleston Area Med. Ctr., 422 S.E.2d 827, 836-37 (W. Va. 1992); Cardwell v. Bechtol, 724 S.W.2d 739, 748 (Tenn. 1987) (comparing standards).
} 
and demeanor of the minor at the time of the incident involved. Moreover, the totality of the circumstances, the nature of the treatment and its risks or probable consequences, and the minor's ability to appreciate the risks and consequences are to be considered. ${ }^{228}$

There is a rich body of scholarship and empirical research operationalizing notions of treatment decisionmaking competence and measuring minors' capacities to make health care decisions. Yet, it is unclear how an evaluator-whether a health care professional or a judge - should assess the broad spectrum of additional variables cited in the above quotation from Cardwell v. Bechtol. Indeed, in those cases in which the broader "maturity" standard is suggested, the courts lay out an extraordinarily sweeping and open-ended list of factors such as "age, ability, experience, education, training, and degree of maturity or judgment." 229

The concept of "maturity" as a condition for independent health care decisionmaking by minors has existed in the context of abortion law for decades, ${ }^{230}$ and thus, theoretically, could serve as a useful model. Unfortunately, the abortion context provides a poor guide or analogy for delineating what "maturity" means, in that there is no consensus about, or even systematic discussion of, the standard. Some have proposed that the concept of maturity in the context of abortion be focused on competence to make health care treatment decisions. ${ }^{231}$ Indeed, the Restatement of Children and the Law adopts this competence-based definition of maturity in the context of minor's abortion decisionmaking. ${ }^{232}$

Yet, unfortunately, the controversial nature of abortion law in this country, and the range of viewpoints about regulation of adolescent sexual activity, appear to influence judicial assessments of minors' maturity in the courtroom. Indeed, some judges impose an unattainably high standard of

${ }^{228}$ Cardwell, 724 S.W.2d at 748.

${ }^{229} \mathrm{Id}$.

${ }^{230}$ In Bellotti v. Baird, the U.S. Supreme Court upheld the parental consent requirement where states provided a procedure allowing minors to demonstrate maturity to a judge as one means to bypass the requirement. 443 U.S. 662, 623 (1979) (plurality opinion). Many states have, therefore, codified this requirement. See, e.g., IND. CODE § 16-34-2-4(e) (West, Westlaw through 2020 Second Regular Sess. of the 121st General Assembly) (allowing a minor to bypass parental consent requirement for abortion if she can demonstrate to a court that she is mature enough to make the abortion decision, or that having the abortion is in her best interests). Other sections of this statute were struck down as unconstitutional in Planned Parenthood v. Comm'r, Ind. Dep't of Health, 258 F. Supp. 3d 929 (S.D. Ind. 2017).

${ }^{231}$ Gary B. Melton \& Anita J. Pliner, Adolescent Abortion: A Psycholegal Analysis, in ADOLESCENT ABORTION: PSYCHOLOGICAL AND LEGAL ISSUES 1, 11-12, 18-19 (Gary B. Melton ed., 1986).

232 RESTATEMENT OF CHILDREN AND THE LAW $\$ 19.02$ (AM. LAw InST., Tentative Draft Two 2019) (defining a "mature minor" as one who is "capable of giving informed consent to the proposed medical treatment," and authorizing mature minors to consent independently to abortion and to choose whether her parents are notified of her choice). 
maturity ${ }^{233}$ seemingly entangled with judicial values and attitudes toward abortion and teenage sexuality. ${ }^{234}$ Thus, the maturity standard applied in the context of adolescent abortion provides a poor model for more general application to minors' health care decisionmaking. ${ }^{235}$

The inherent malleability of the concept of "maturity" as the key that opens the door to health care decisionmaking choices for minors may allow it to embody social preferences regarding access or barriers to treatment for minors. ${ }^{236}$ The broader and vaguer the test of maturity, the greater is the

${ }^{233}$ Indeed, Elizabeth Scott refers to the maturity test in the context of abortion bypass hearings to be a "rather vague prescription" and "indeterminate legal standard," and observes:

[J]udicial judgments about where the line between childhood and adulthood should be drawn often seem to depend on attitudes about abortion and teen pregnancy. Some conservative courts raise the bar very high, evaluating petitioners under a standard for general maturity that most minors are unlikely to meet. One is sometimes left to conclude that a "mature" minor would have consulted with her parents (and thus have no need for the judicial by-pass procedure), and probably would never have been foolish enough to become pregnant. Other courts appear to rubber-stamp petitions by pregnant teens [and seem] motivated largely by a paternalistic concern for the health and welfare of pregnant minors [who may otherwise go on to become teen parents], rather than by any deference for adolescent autonomy.

Elizabeth S. Scott, The Legal Construction of Adolescence, 29 HOFSTRA L. REV. 547, 574-75 (2000) (internal citations omitted).

${ }^{234}$ For example, Carol Sanger indicates:

To determine if [a minor] is mature enough [to make the abortion decision], a number of judges ask what they consider to be relevant questions about her circumstances. These often include such questions as why she got pregnant, whether she knows about birth control now so that this will not happen again, and why she will not involve her parents in the process... I suspect that the purpose of these hearings is less an attempt to assure a sound decision regarding the abortion than it is an attempt to humiliate young women-in old socio-legal terms, it is an attempt to use the process itself as punishment. The court is supposed to be making a maturity determination, but in looking through cases where petitions have been denied, it is evident that something more than a display of maturity is sought. Some indication or display of contrition or remorse is also valued, and rewarded.

Carol Sanger, The Role and Reality of Emotions in Law, 8 WM. \& MARY J. WOMEN \& L. 107, 111-12 (2001) (internal citations omitted). See also Carol Sanger, Decisional Dignity: Teenage Abortion, Bypass Hearings, and the Misuse of Law, 18 COLUM. J. GENDER \& L. 409, 499 (2009) (further developing the theme that judicial bypass hearings serve to punish pregnant teens rather than play an evaluative function).

${ }^{235}$ Coleman and Rosoff suggest that the criteria used to assess maturity in the abortion context are reasonable for assessing minors' maturity to make health care decisions more generally. Coleman \& Rosoff, supra note 15, at 792 (citing "aspects of the child's development and experience including age, level of education, success in school, engagement in work or other extracurricular activities, disciplinary issues, and future plans"). As in the context of abortion, however, broad criteria invite greater subjectivity in application. Furthermore, policy considerations may argue for different standards of maturity in different treatment contexts. As discussed below, standards and thresholds of maturity or competence may most appropriately vary with the risk/benefit profile of the intervention in question.

${ }^{236}$ Michelle Oberman suggests that the concept of maturity in the context of health care decisionmaking "operates as a code word, invoked to permit minors access to treatments that society 
likelihood that it will serve as a repository for unstated values either about the treatment in question or minors' access to or refusal of it. A narrower and more specific standard of maturity, such as one that focuses on skills and abilities traditionally associated with capacity to make health care decisions, can be more easily operationalized and assessed.

\section{iii. Treatment-Specific Statutes Authorizing Minors' Independent Access to Treatment}

Throughout the past several decades, legislatures have lowered the age of legal consent for minors' access to certain health care interventions, primarily with respect to access to services for contraception, abortion, teen pregnancy, mental health and substance abuse disorders, sexually transmitted diseases, and sexual assault. ${ }^{237}$ In contrast to dependency determinations, these exceptions to the doctrine of parental consent are not premised on a finding of parental unfitness and do not subject the family to intrusive investigation and regulation. Rather, most are narrowly tailored authorizations for minors to choose for themselves in contexts in which there are strong social interests in promoting minors' access to services.

The rationales for such statutory enactments include a complex mix of constitutional, policy, and practical factors that vary across the types of health care involved. However, there are many commonalities among these exceptions. First, and importantly, the state has strong parens patriae and police power interests in minors' receipt of the services specified in most of these exceptions, ${ }^{238}$ to be discussed in greater detail with respect to each of

deems desirable," and to limit access when there exist social concerns about potential negative consequences. Michelle Oberman, Minor Rights and Wrongs, 24 J.L. MED. \& ETHICS 127, 127 (1996). She asserts that the "present system works not because minors are mature, but because of the tacit utilitarian calculus that govern minors' access to care." Id.

${ }^{237}$ Some of these legislative changes related to access to contraception and abortion specifically preceded, while others followed federal and state court decisions delineating the parameters of minors' constitutional rights to these services without parental consent and, in some cases, without notice to parents. See, e.g., Maya Manian, Minors, Parents, and Minor Parents, 81 Mo. L. ReV. 127, 133-46 (2016).

${ }^{238}$ We recognize that abortion is a form of treatment about which there is substantial controversy in this country, and therefore acknowledge that some would challenge the premise that a state has an interest in facilitating minors' access. Indeed, some state legislatures have recently sought to limit or eliminate the availability of abortion, indicating a view that such availability is not in the state's interest. See Sabrina Tavernise, "The Time is Now": States Are Rushing to Restrict Abortion, or to Protect It, N.Y. TiMES (May 15, 2019), https://www.nytimes.com/2019/05/15/us/abortion-laws-2019.html (discussing states' approaches to the issue).

Analysis of the right to abortion, unlike the other treatment categories listed here, is made more complex by the state's acknowledged interest in protecting the future life of the fetus, as well as the concern by some that abortion decisions may have deleterious emotional repercussions for women. See, e.g., Gonzales v. Carhart, 550 U.S. 124, 159 (2007) ("While we find no reliable data to measure the phenomenon, it seems unexceptionable to conclude some women come to regret their choice to abort the infant life they once created and sustained .... Severe depression and loss of esteem can follow ... a decision so fraught with emotional consequence ...."); Planned Parenthood v. Casey, 505 U.S. 833, 852 
the exceptions below. Of course, the state has such interests in many forms of treatment for which there are not statutory exceptions authorizing independent consent by minors. Thus, other factors converge with these state interests to explain why states allow minors to consent to these services.

Second, one distinction between these treatment contexts and the run-of-the-mill treatment for appendicitis or strep throat lies in the "sensitive" nature of services related to sexual activity, pregnancy, mental health, substance abuse, or sexual assault. While many parents may be fully supportive of their minor children who seek to access these services, others may be less so. The presumption, discussed above, ${ }^{239}$ that there is an identity of interests between parent and child, does not hold when an older minor seeks to access services and his or her parent wants to prevent such access. Arguably, in these circumstances, a conflict of interests exists, undercutting one of the bases on which the doctrine of parental consent is premised. ${ }^{240} \mathrm{In}$ an influential 1973 article, Hillary Rodham argued that:

(1992) ("Abortion is . . f fraught with consequences for others: for the woman who must live with the implications of her decision; for the persons who perform and assist in the procedure; for the spouse, family, and society which must confront the knowledge that these procedures exist, procedures some deem nothing short of an act of violence against innocent human life; and, depending on one's beliefs, for the life or potential life that is aborted."). Some Justices suggest these asserted effects are enhanced for minors. See, e.g., H. L. v. Matheson, 450 U.S. 398, 411 (1981) ("The medical, emotional, and psychological consequences of an abortion are serious and can be lasting; this is particularly so when the patient is immature.").

Yet, these assertions by some members of the Court have been challenged by other Justices citing research analyzed by key scientific organizations. See, e.g., Gonzales, 550 U.S. at 183-84 n.7 (Ginsburg, J., dissenting) (citing psychological literature contradicting majority assertions). See also M. Antonia Biggs et al., Women's Mental Health and Well-Being 5 Years After Receiving or Being Denied an Abortion: A Prospective, Longitudinal Cohort Study, 74 JAMA PsYCHIATRY 169, 169 (2017) (“[B]eing denied an abortion may be associated with initially experiencing adverse psychological outcomes."); Diana Greene Foster et al., Comparison of Health, Development, Maternal Bonding and Poverty Among Children Born After Denial of Abortion vs After Pregnancies Subsequent to an Abortion, 172 JAMA PEDIATRICS 1053, $1053 \quad$ (2018) (“[A]ccess to abortion enables women to choose to have children at a time when they have more financial and emotional resources to devote to their children."); BIXBY CTR. FOR GLOB. REPROD. HEALTH, UCSF, TURNAWAY STUDY, https://www.ansirh.org/sites/default/files/publications/files/turnaway_study_brief_web.pdf (last visited Mar. 17, 2020) (summary of findings) (“Abortion does not increase women's risk of having suicidal thoughts, or the chance of developing PTSD, depression, anxiety, low self-esteem, or lower life satisfaction."). Studies examining mental health and life circumstances of women who had abortions during adolescence or prior to age twenty-one report no greater likelihood of detrimental mental health consequences for those who had abortions as compared with women who had continued an unintended pregnancy. Jocelyn T. Warren, S. Marie Harvey \& Jillian T. Henderson, Do Depression and Low Self-Esteem Follow Abortion Among Adolescents? Evidence from a National Study, 42 PERSP. ON SEXUAL \& ReProd. HeAlth 230, 233 (2010); David M. Fergusson, Joseph M. Boden \& L. John Horwood, Abortion Among Young Women and Subsequent Life Outcomes, 39 PERSP. ON SEXUAL \& REPROD. HEALTH 6, 11 (2007).

${ }^{239}$ See infra notes $127-29$ and accompanying text.

${ }^{240}$ See Jennifer Rosato, Using Bioethics Discourse to Determine When Parents Should Make Health Care Decisions for Their Children: Is Deference Justified?, 73 TEMP. L. REv. 1, 43 (2000) (arguing for a "conflict of interest exception" when the interests of the family do not coincide with those of the 
[T] he presumption of identity of interests between parents and their children should be rejected whenever the child has interests demonstrably independent of those of his parents (as determined by the consequences to both of the action in question), and a competent child should be permitted to assert his or her own interests. ${ }^{241}$

These statutory exceptions attempt to address this type of scenario.

A third, and related, barrier to care exists. Many minors are hesitant to inform their parents of their need for services if it requires disclosing that they are sexually active, that they are experiencing mental or emotional problems, that they are using or abusing certain substances, or that they have been victims of sexual assault. These are sensitive matters, and many minors would rather forego seeking treatment than involve their parents. ${ }^{242}$ Even when minors do not fear adverse parental reactions, they may be uncomfortable or embarrassed about talking with their parents about these issues and therefore refrain from such discussions. In some cases, minors may suspect, accurately or inaccurately, that their parents will deny consent for, or otherwise prevent them from accessing, these services. In other cases, the minors may fear negative repercussions from disclosure to parents. ${ }^{243}$ They may fear being "grounded" or having their conduct otherwise restricted. They may fear other disciplinary measures or reprisals, or perhaps even physical or emotional abuse by their parents. Regardless of the accuracy of minors' concerns about informing their parents of their need for treatment, the concerns create barriers. Parents are not capable of acting in their children's best interests if their children do not inform them of their needs. An alternative consent mechanism to promote the minors' best interests must exist as a supplement to parental consent. The statutory exceptions create such an alternative.

\footnotetext{
patient).

${ }^{241}$ Rodham, supra note 127 , at 507.

${ }^{242}$ Janine P. Felsman, Eliminating Parental Consent and Notification for Adolescent HIV Testing: A Legitimate Statutory Response to the AIDS Epidemic, 5 J.L. \& POL’Y 339, 383 (1996) (“[M]inors may forego HIV testing rather than reveal their high risk behavior to their parents."); Doris G. Kaplan, Right of Privacy of Minors: Statutory Self-Consent in Oklahoma, 54 OKLA. B.J. 1724, 1728 (1983) (stating that "the minor, threatened with revealing sensitive personal problems may forego treatment to avoid conflict, abuse or alienation at home"). See also supra notes 245, 290-95, 303-09 and accompanying text and Section III.C.

${ }^{243}$ H. L. v. Matheson, 450 U.S. 398, 438-39 (1981) (Marshall, J., dissenting) (observing that "[m]any minor women will encounter interference from their parents[,]" "parental disappointment and disapproval," or "physical or emotional abuse, withdrawal of financial support, or actual obstruction of the abortion decision"); Melissa Weddle \& Patricia K. Kokotailo, Confidentiality and Consent in Adolescent Substance Abuse: An Update, 7 ETHICS JAMA 239, 240 (2005) (noting that among adolescents who do not involve parents in health care decisions, some "have experienced violence within the family, and they fear incurring violence" if parents are involved in the treatment process).
} 
Fourth, as discussed in Section II.B.1.ii, there exist constitutional, bioethical, and policy rationales for permitting minors to exercise autonomy and choose for themselves in the health care matters for which these exceptions exist.

Fifth, the presumption that adolescents are not capable of making wise decisions regarding their own medical care has not been confirmed by the relevant science. Below, we review the state of knowledge regarding children's competence to consent to treatment. ${ }^{244}$ In general, research indicates that most adolescents are psychologically capable of making health care decisions in a manner that satisfies legal standards of competence. The ages at which these abilities are sufficiently adult-like to meet such standards typically coincide with the ages identified by those statutes creating treatment-specific exceptions at the age of consent. While other statutes creating treatment-specific exceptions may not identify an age of consent, there appears to be substantial overlap in age between minors who are likely to seek the services made available to them under the statutes and those who are likely to be competent to consent. For example, data reveal that most minors who are sexually active are usually age fifteen or older. ${ }^{245}$ Abuse of alcohol and drugs by minors usually begins in adolescence as well. ${ }^{246}$ Although mental health problems and victimization by sexual assault can occur throughout minority, there are higher rates of both problems in adolescence than at younger ages. ${ }^{247}$ Given that studies suggest that minors have developed decisionmaking skills that enable them to satisfy legal tests

${ }^{244}$ See infra Section III.B.3.

${ }^{245}$ Guttmacher Inst., American Teens' Sexual and Reproductive Health Fact Sheet, SANDERS INST. (Aug. 2017), available at https://www.sandersinstitute.com/blog/american-teens-sexual-andreproductive-health-fact-sheet.

On average, young people in the United States have sex for the first time at about age 17 , but do not marry until their mid-20s

In 2011-2013, among unmarried 15-19-year-olds, $44 \%$ of females and $49 \%$ of males had had sexual intercourse. These levels have remained steady since 2002.

The proportion of young people having sexual intercourse before age 15 has declined in recent years. In 2011-2013, about 13\% of never-married females aged 15-19 and $18 \%$ of never-married males in that age-group had had sex before age 15 , compared with $19 \%$ and $21 \%$, respectively, in 1995 .

Id. (footnotes omitted)

${ }^{246}$ Principles of Adolescent Substance Disorder Treatment: A Research-Based Guide, NAT'L INSTITUTES HEALTH, https://www.drugabuse.gov/publications/principles-adolescent-substance-usedisorder-treatment-research-based-guide/introduction (last updated Jan. 2014).

${ }^{247}$ See, e.g., Children and Teens: Statistics, RAPE ABUSE \& INCEST NAT'L NETWORK (RAINN), available at https://www.rainn.org/statistics/children-and-teens (indicating that two-thirds of the sexual assaults of minors involve adolescent victims); Data and Statistics on Children's Mental Health, CENTERS FOR DISEASE CONTROL \& PREVENTION, https://www.cdc.gov/childrensmentalhealth/data.html (revealing that adolescence is the stage of minority in which the highest rates of depression and anxiety occur). 
of competence by age fourteen, and in many cases, by ages twelve or thirteen, ${ }^{248}$ it is likely that most minors seeking the services for which the statutory exceptions are created would meet legal standards of competence. $^{249}$

The following types of health care services are those most commonly the subject of exceptions that allow minors to access services without parental consent: (1) contraception; (2) prenatal care; (3) abortion; (4) testing and treatment for sexually transmitted diseases (STDs), including human immunodeficiency virus (HIV) and acquired immunodeficiency syndrome (AIDS); (5) substance abuse or mental health treatment; and (6) sexual assault related services, including counseling, testing, and medical care. $^{250}$

${ }^{248}$ See infra Section III.B.3

${ }^{249}$ Below, we also discuss further the question of what threshold should exist in competence determinations. See infra Section III.B.3. As we indicate, the dividing line between competence and incompetence is a policy choice that reflects analysis of competing legal, bioethical, and practical factors. To the extent that there is a strong social interest in promoting minors' access to certain services, and these services expose minors to low levels of risk, and are likely to provide a high level of benefit, the threshold for capacity may be placed somewhat lower than it would for health care interventions invoking less compelling social interests and/or with different risk/benefit profiles. See infra notes 367-69 and accompanying text.

${ }^{250}$ Two categories of exceptions are not discussed here. First, there is a limited exception to the requirement of parental consent for emergency care. This exception has existed for over a century. See HOLDER, supra note 212, at 125 n.6. We do not include it within the treatment-specific exceptions listed here because it is not specific to minors, and therefore does not provide a useful analogy for our proposed exception to the parental consent requirement in the context of vaccinations. It applies to patients of all ages, and is a mechanism that allows health care providers to dispense with informed consent requirements for a condition risking serious injury or death, where the treatment is one for which it can be reasonably presumed the patient would have given consent and "the time it would take to offer an informed consent would significantly increase the patient's risk of mortality and morbidity." STEPHEN Wear, Informed Consent: Patient Autonomy and Clinician Beneficence Within Health CARE 156-57 (2d ed. 1998). See also Kurt M. Hartman \& Bryan D. Liang, Exceptions to Informed Consent in Emergency Medicine, HOSP. PHYSICIAN, Mar. 1999, at 53, 54-55. In the case of an adult, the patient may be competent, but there is no time to go through the informed consent process without serious detrimental consequences. Alternatively, the patient may be unconscious or otherwise unable to provide legally valid consent, and delaying treatment to contact a substitute decision maker seriously risks the patient's health. Thus, as applied to minors, it allows providers to treat a child of any age whose circumstances meet the criteria without waiting until parents can be reached for consent. HOLDER, supra note 212 , at 125 .

Second, we do not address the emancipation exception, which gives minors who are legally emancipated the sole authority to consent to their own health care. Vivian E. Hamilton, Adulthood in Law and Culture, 91 Tul. L. REV. 55, 70 (2016) ("Emancipated minors step into the shoes of their parents, exercising for themselves the authority that parents would normally exercise over them."). See generally Carol Sanger \& Eleanor Willemsen, Minor Changes: Emancipating Children in Modern Times, 25 U. Mich. J.L. REFORM 239, 258-60 (1992). Typically, conduct that is consistent with assumption of adult responsibilities or roles (such as financial independence, marriage, military service) serves as the basis for a determination that the minor is emancipated. This exception is not relevant to our proposal because we are not positing that minors' access to vaccinations independent of parental consent be contingent on a determination that the minor is emancipated. 
iv. Contraception

Public health efforts over several decades, including the development and proliferation of sex education curricula, have sought to reduce teen pregnancy. ${ }^{251}$ The Centers for Disease Control and Prevention report that "[t]een pregnancy and childbearing bring substantial social and economic costs through immediate and long-term impacts on teen parents and their children." ${ }^{252}$ For example, according to the Centers for Disease Control and Prevention:

Pregnancy and birth are significant contributors to high school dropout rates among girls. Only about $50 \%$ of teen mothers receive a high school diploma by 22 years of age, whereas approximately $90 \%$ of women who do not give birth during adolescence graduate from high school.

The children of teenage mothers are more likely to have lower school achievement and to drop out of high school, have more health problems, be incarcerated at some time during adolescence, give birth as a teenager, and face unemployment as a young adult. ${ }^{253}$

Clearly, the state's parens patriae and police power interests are implicated in preventing teen pregnancy, as are the interests of minors who could become pregnant and the interests of the children they might bear. Facilitating minors' access to contraception furthers these parens patriae and police power goals of reducing the burdens accompanying teen pregnancy, for those directly affected, and the general public that will share many of the costs of teen pregnancies. Sex education programs together with adolescent access to family planning services are credited with reducing the teen birth rate by $64 \%$ between 1991 and 2015, resulting in an estimated " $\$ 4.4$ billion in public savings in 2015 alone." 254

In addition, availability of certain forms of contraception also reduces transmission of sexually transmitted diseases. ${ }^{255}$ Almost half of the cases of such diseases in the United States are in the adolescent and young adult groups, ages fifteen to twenty-four. ${ }^{256}$ Researchers attribute this

${ }^{251}$ Comm. on Adolescent Health Care, Adolescent Pregnancy, Contraception, and Sexual Activity, AM. C. OBSTETRICIANS \& GYNECOLOGISTS (May 2017), https://www.acog.org/Clinical-Guidance-andPublications/Committee-Opinions/Committee-on-Adolescent-Health-Care/Adolescent-PregnancyContraception-and-Sexual-Activity?IsMobileSet=false.

252 Reproductive Health: Teen Pregnancy, CENTERs FOR DiseAsE CONTROL \& PREVENTION, https://www.cdc.gov/teenpregnancy/about/index.htm (last reviewed Mar. 1, 2019).

${ }^{253}$ Id.

${ }^{254} \mathrm{Id}$.

${ }^{255}$ Comm. on Adolescent Health Care, supra note 251.

${ }^{256}$ Guttmacher Inst., supra note 245. 
disproportionality to "disparities in accessing preventive information and services, ${ }^{257}$ revealing the dramatic effects of barriers to care.

The Guttmacher Institute reports that as of October 2019, twenty-three states and the District of Columbia expressly allow all minors to consent independently to contraceptive services. ${ }^{258}$ Twenty-four states allow minors to consent independently to contraceptive services if certain conditions are met. ${ }^{259}$ For example, eight of these states permit minors who are deemed to be "mature" or who have reached the age of twelve or fourteen years old to consent. ${ }^{260}$ Most of these states permit minors who are married to consent. ${ }^{261}$ Four states do not have a statutory policy on minors' consent for contraceptive services. ${ }^{262}$

\section{v. Prenatal Care}

Adequate prenatal care for minors promotes their own health during pregnancy and childbearing and gives their offspring the best chance at a healthy future. ${ }^{263}$ Concern about their own parents' reactions to the pregnancy has been cited as one of the reasons why minors delay accessing prenatal care. ${ }^{264}$ As of October 2019, thirty-seven states and the District of Columbia permit minors to have independent access to prenatal services, although fifteen of those states permit, but do not require, notification of such services to the pregnant minors' parents. ${ }^{265}$

vi. Abortion

As noted above, teen pregnancy entails medical and social risks for the adolescent and her future offspring, as well as substantial economic costs to

${ }^{257} I d$.

258 Minors' Access to Contraceptive Services, GUTTMACHER Inst. (Oct. 1, 2019), https://www.guttmacher.org/state-policy/explore/minors-access-contraceptive-services.

${ }^{259} \mathrm{Id}$.

${ }^{260} \mathrm{Id}$.

${ }^{261}$ See id. (reporting that nineteen of the twenty-four states allow a married minor to consent to contraceptive services).

${ }^{262} I d$.

${ }^{263}$ See, e.g., Byron C. Calhoun, Healthy Management of Very Early Adolescent Pregnancy, 31 Issues L. \& MED. 191, 195 (2016) (reporting that early prenatal care may help prevent adverse outcomes in adolescent pregnancy); Katherine Moore, Pregnant in Foster Care: Prenatal Care, Abortion, and the Consequences for Foster Families, 23 COLUM. J. GENDER \& L. 29, 64 (2012) (demonstrating efficacy of early intervention programs serving minors).

${ }^{264}$ See Sally Hughes Lee \& Laurie M. Grubbs, Pregnant Teenagers' Reasons for Seeking or Delaying Prenatal Care, 4 CLINICAL NuRSING RES. 38, 42 (1995) (reporting findings that $41.6 \%$ of teens delayed prenatal care because of fear that their pregnancies would be disclosed to their parents).

265 See Minors' Access to Prenatal Care, GutTMACHER Inst. (Oct. 1, 2019), https://www.guttmacher.org/state-policy/explore/minors-access-prenatal-care (reporting that fifteen of the thirty-seven states allow physicians to maintain the minor's confidentiality if doing so is in the best interest of the minor). 
these individuals and the public. ${ }^{266}$ The American Academy of Pediatrics asserts that, in addition to pregnancy prevention efforts, legal policies should permit medically safe pregnancy termination when minors seek to end an unintended pregnancy. ${ }^{267}$ In a 2017 Policy Statement, the Academy stated:

The American Medical Association, the Society for Adolescent Health and Medicine, the American Public Health Association, the American College of Obstetricians and Gynecologists, the AAP, and other health professional organizations have reached a consensus that a minor should not be compelled or required to involve her parents in her decision to obtain an abortion, although she should be encouraged to discuss the pregnancy with her parents and/or other responsible adults. These conclusions result from objective analyses of current data, which indicate that legislation mandating parental involvement does not achieve the intended benefit of promoting family communication but does increase the risk of harm to the adolescent by delaying access to appropriate medical care or increasing the rate of unwanted births. ${ }^{268}$

State laws governing minors' access to abortion are complex, revealing many variations among states. ${ }^{269}$ The U.S. Supreme Court has held that if a state requires parental consent for abortion, it must provide minors with an option to bypass parental consent, such as the opportunity to demonstrate to a judge that she is mature enough to make her own abortion decision or that the abortion is in her best interests. ${ }^{270}$ Some states, however, while allowing minors to consent independently to abortion, require notification of the minors' parents. ${ }^{271}$ This type of provision has been upheld by the U.S. Supreme Court, as long as the laws contain certain exceptions identified by the Court, such as a judicial bypass procedure. ${ }^{272}$ As of October 1, 2019,

${ }^{266}$ See Reproductive Health: Teen Pregnancy, supra note 252 (illustrating the substantial social and economic costs of teen pregnancy).

${ }^{267} \mathrm{Am}$. Acad. Of Pediatrics Comm. on Adolescence, The Adolescent's Right to Confidential Care When Considering Abortion, 139 PEDIATRICS 1, 1 (2017), https://pediatrics.aappublications.org/content/ pediatrics/139/2/e20163861.full.pdf.

${ }^{268} I d$. at 2.

269 See Parental Involvement in Minors' Abortions, GUTTMACHER INST. (Oct. 1, 2019), https://www.guttmacher.org/state-policy/explore/parental-involvement-minors-abortions (reporting patterns in state regulation of minors' access to abortions).

${ }^{270}$ Bellotti v. Baird, 443 U.S. 662, 643-44 (1979).

${ }^{271}$ Parental Involvement in Minors' Abortions, supra note 269.

${ }^{272}$ See Ayotte v. Planned Parenthood of Northern New England, 546 U.S. 320, 327 (2006) (holding unconstitutional a New Hampshire parental notification statute that does not allow a physician to perform an abortion at a minor's request in a medical emergency without parental notification); Ohio v. Akron Ctr. for Reprod. Health, 497 U.S. 502, 502 (1990) (upholding an Ohio statutory provision requiring a physician to notify the parent of a minor prior to performing an abortion, unless the minor is able to 
twenty-six states required parental consent for minors' abortions, and eleven states required notification only. ${ }^{273}$ In three parental consent states, and three parental notification states, the policies have been judicially enjoined and are not in effect. ${ }^{274}$ Seven of the states that require either parental consent or notification allow other relatives, such as a grandparent, to substitute for the parent at the minor's request. ${ }^{275}$ The remaining states do not have parental consent or notification requirements for minors' access to abortion.

The parental involvement laws and the required judicial bypass procedure have been the subject of much criticism because of barriers and burdens that attend this process, the inconsistency in standards applied in adjudicating maturity and best interests, and the lack of evidence that the policies have a positive impact on teenagers' sexual and reproductive health, promote better decisionmaking about abortion by teenagers, or improve parent-child communication. ${ }^{276}$ Research reveals that teenagers seeking abortions without parental consent may face challenging and potentially insurmountable barriers, including locating a judge who conducts abortion by-pass hearings, finding transportation to the courthouse (particularly in rural states), taking time off from school, and dealing with the challenges of presenting their case to the judge. ${ }^{277}$ Furthermore, the process can be "traumatic and stress inducing" and may lead to delay in receiving services, with deleterious medical and psychological repercussions. ${ }^{278}$

demonstrate by clear and convincing evidence in a judicial bypass hearing that she is mature enough to make the abortion decision on her own, that the notice is not in her best interests, or that she has been a victim of abuse perpetrated by a parent); Hodgson v. Minnesota, 497 U.S. 417, 417 (1990) (upholding as constitutional a Minnesota statute that required that notice be given to both parents of a minor prior to performing an abortion, as long as the statute provides for a judicial bypass procedure); H. L. v. Matheson, 450 U.S. 398, 398 (1981) (holding unconstitutional a statutory requirement that a physician notify the parents of an unmarried, dependent girl prior to performing an abortion as applied to a girl who was immature and unemancipated).

${ }^{273}$ See Parental Involvement in Minors ' Abortions, supra note 269 (reporting that twenty-one states require parental consent, three of which require both parents' consent and five of which require both parental notification and consent).

${ }^{274}$ See id. (reporting that courts permanently enjoined enforcement of statutes in Alabama, California, Nevada, New Jersey, and New Mexico, and temporarily enjoined the Montana statute).

${ }^{275} I d$.

${ }^{276}$ See Maya Manian, Functional Parenting and Dysfunctional Abortion Policy: Reforming Parental Involvement Legislation, 50 FAM. CT. REV. 241, 244-46 (2012) (analyzing the inefficacy of the judicial bypass procedure in improving outcomes for pregnant teens); Carol Sanger, Decisional Dignity: Teenage Abortion, Bypass Hearings, and the Misuse of Law, 18 COLUM. J. GENDER \& L. 409, 414 (2009) (arguing that the judicial bypass process is unnecessary and works to humiliate and insult young women).

${ }^{277}$ See Ira Mark Ellman, Paul KuRTZ \& Lois A. Weithorn et Al., FAmily LaW: CASeS, TeXT, Problems 1203-04 (5th ed. 2010); Manian, supra note 276, at 244; Sanger, supra note 276, at 439; see

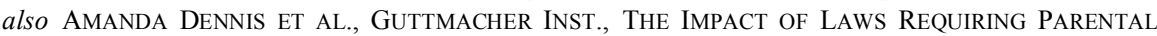
INVOLVEMENT FOR ABORTION: A LITERATURE REVIEW 1 (2009), https://www.guttmacher.org/sites/ default/files/report_pdf/parentalinvolvementlaws.pdf (finding that parental involvement laws increase minors' interstate travel to avoid these restrictions).

${ }^{278}$ See Manian, supra note 276, at 244 (describing the stress experienced by minors undergoing the judicial bypass process); Sanger, supra note 276, at 429, 461 (asserting that the judicial bypass process 
vii. Sexually Transmitted Diseases and Human Immunodeficiency Virus

Sexually transmitted diseases (STDs), including human immunodeficiency virus (HIV) and acquired immunodeficiency syndrome (AIDS), are infectious diseases spread through human sexual contact. They can lead to serious, and at times deadly, consequences if untreated. ${ }^{279}$ Most of these conditions are responsive to treatment. ${ }^{280}$ Timely medical care for minors who have been exposed to these conditions is essential to promote the health of a minor seeking services and others who have been, or but for timely medical intervention might be, exposed to these contagious diseases. Research surveying the attitudes of teens toward seeking needed services for STDs reveals that the adolescents' fears of their parents' reactions could lead them to avoid seeking medical services. ${ }^{281}$ Researchers emphasize the importance of providing minors with independent access to services for STDs and with guarantees of confidentiality. ${ }^{282}$

All fifty states and the District of Columbia provide some form of access by minors to prevention, testing, or treatment services related to STDs and HIV without parental consent. Some states permit, but do not require, practitioner notification of parents. ${ }^{283}$

\section{viii. Mental Health or Substance Abuse Treatment}

One in five adolescents has suffered from a serious mental health disorder at some point during his or her minority. ${ }^{284}$ Despite the existence of effective treatments, fewer than half of adolescents with such conditions

\footnotetext{
does not have beneficial medical or psychological implications for teens); see also DENNIS ET AL., supra note 277 , at 1 (reporting study findings that judicial bypass requirements lead minors to travel to states with less restrictive abortion policies). For a qualitative study of teens who made abortion decisions without involving their parents, see J. Shoshanna Ehrlich, Grounded in the Reality of Their Lives: Listening to Teens Who Make the Abortion Decision Without Involving Their Parents, 18 BERKELEY WOMEN's L.J. 61, 65 (2003).

279 See CDC Fact Sheets, Centers for Disease Control \& Prevention: SeXually TRANSMITTED DISEASES (STDS), https://www.cdc.gov/std/healthcomm/fact_sheets.htm (containing fact sheets on various STDs).

${ }^{280} I d$.

${ }^{281}$ Jami S. Leichliter et al., Confidentiality Issues and Use of Sexually Transmitted Disease Services Among Sexually Experienced Persons Aged 15-25 Years-United States, 2013-2015, 66 MORBIDITY \& MORTALITY WKLY. REP. 237, 237, 239-40 (2017).

${ }^{282}$ Id. at 240; Gale R. Burstein et al., Position Paper: Confidentiality Protections for Adolescents and Young Adults in the Health Care Billing and Insurance Claims Process, $58 \mathrm{~J}$. AdOLESCENT HEALTH 374, 375 (2016), https://www.jahonline.org/article/S1054-139X(15)00723-5/pdf.

${ }^{283}$ Minors' Consent Laws for HIV and STD Services, CENTERS FOR DiSEASE CONTROL \& PREVENTION, https://www.cdc.gov/hiv/policies/law/states/minors.html (last updated Nov. 30, 2018).

${ }^{284}$ Office of Adolescent Health, Mental Health in Adolescents, U.S. DeP'T Health \& Hum. SERVICES, https://www.hhs.gov/ash/oah/adolescent-development/mental-health/index.html (last reviewed Feb. 24, 2017).
} 
seek treatment. ${ }^{285}$ Research indicates that "[m]ental and substance use disorders are the leading cause of disability in children and youth worldwide," surpassing other medical conditions. ${ }^{286}$ More generally, we have learned in recent years that mental health conditions are among the most costly - and are perhaps even the most costly - category of illnesses in terms of its lifetime burden of disability. ${ }^{287}$ One of the reasons for this effect is that, unlike heart disease and many other chronic medical conditions, mental health disorders often present early in life and can limit the opportunities for full and healthy participation in various spheres for those affected throughout the lifespan. ${ }^{288}$ Early diagnosis and treatment is in the interests of both the person with the condition and of society at large. In addition, rates of suicidality (considering, attempting, and committing suicide) among adolescents are high. ${ }^{289}$ Related to mental health conditions, use and abuse of various illicit substances by adolescents is common, unfortunately, and presents a myriad of short- and long-term risks to those using such substances, including detrimental effects on the developing brain. ${ }^{290}$ Medical professionals indicate that early intervention is essential to give minors the best opportunity at a healthy life and to avoid or recover from damaging physical and psychological effects of substance abuse. ${ }^{291}$

In the context of both mental health and substance abuse treatment, concerns about confidentiality constitute significant barriers, and are perceived by mental health and medical professionals as a deterrent to adolescent help-seeking. ${ }^{292}$ Unfortunately, in our society, there is substantial stigma associated with mental disorders, leading to bias, discrimination, and

${ }^{285} I d$.

${ }^{286}$ H.E. Erskine et al., A Heavy Burden on Young Minds: The Global Burden of Mental and Substance Use Disorders in Children and Youth, 45 PSYCHOL. MED. 1551, 1558 (2015) (emphasis added).

${ }^{287}$ See, e.g., Sebastian Trautmann et al., The Economic Costs of Mental Disorders: Do Our Societies React Appropriately to the Burden of Mental Disorders?, 17 EMBO REP. 1245, 1247 (2016) ("Mental disorders therefore account for more economic costs than chronic somatic diseases such as cancer or diabetes, and their costs are expected to increase exponentially over the next 15 years.'); Daniel Vigo et al., Estimating the True Global Burden of Mental Illness, 3 LANCET PSYCHIATRY 171, 171 (2016) (calculating that mental illness accounts for one-third of the world burden of disability, placing it well ahead of any other category of disorders).

${ }^{288}$ Erskine et al., supra note 286, at 1551-52 ("Half of all cases of mental disorders develop by age 14 years although most remain undetected and untreated until later in life.").

289 CTRS. FOR Disease CONTROL \& PREVEnTION, SuICIDE 1-2 (2015), https://www.cdc.gov/ violenceprevention/pdf/suicide-datasheet-a.pdf; S.K. GOLDSMITH, REDUCING SUICIDE: A NATIONAL IMPERATIVE 33-58 (2002).

${ }^{290}$ AM. ACAD. OF PEDIATRICS, SUBSTANCE USE SCREENING AND INTERVENTION IMPLEMENTATION GUIDE 2-3, 16-19 apps. 2, 3, https://www.aap.org/en-us/Documents/substance_use_screening _implementation.pdf (last visited Mar. 17, 2020).

291 Id.

292 See, e.g., id. at 8-9; Amelia Gulliver, Kathleen M. Griffiths \& Helen Christiansen, Perceived Barriers to Mental Health Help-Seeking in Young People: A Systematic Review, 10 BMC PSYCHIATRY 113 (2010). 
a range of social and psychological repercussions. ${ }^{293}$ The evidence for stigma is even greater in the context of substance abuse disorders. ${ }^{294}$ These biases create barriers to treatment because individuals hesitate to seek services, in part due to fear of the negative repercussions that might flow from disclosure of their conditions to others. ${ }^{295}$ Adolescents seeking such treatments may refrain from discussing their need for treatment with parents. If not guaranteed the same confidentiality as is promised to adults seeking mental health and substance abuse treatment, minors will likely be reluctant to contact providers. ${ }^{296}$

Most states contain an exception to the doctrine of parental consent for substance abuse and mental health treatment. ${ }^{297}$ In some instances, either parent or child can legally consent to such treatment. Statutes authorizing minors' consent may set a minimum age, typically twelve or fourteen years of age, ${ }^{298}$ although New Jersey recently passed legislation authorizing such independent consent at age sixteen. ${ }^{299}$

${ }^{293}$ See GOLDSMITH, supra note 289, at 332-34 (reporting survey results indicating that $45-60 \%$ of Americans wanted to distance themselves from persons with depression or schizophrenia).

${ }^{294}$ Id. at 333; Sarah Wakeman \& Josiah Rich, Barriers to Medications for Addiction Treatment: How Stigma Kills, 53 SubSTANCE USE \& MiSUSE 330, 330 (2018).

${ }^{295}$ Patrick W. Corrigan et al., The Impact of Mental Illness Stigma on Seeking and Participating in Mental Health Care, 15 PSychoL. SCI. PuB. INT. 37, 42-43 (2014).

296 MaryLouise E. Kerwin et al., What Can Parents Do? A Review of State Laws Regarding Decision Making for Adolescent Drug Abuse and Mental Health Treatment, 24 J. CHILD ADOLESCENT SUBSTANCE ABUSE 166, 167 (2015).

${ }^{297}$ See, e.g., Richard C. Boldt, Adolescent Decision Making: Legal Issues with Respect to Treatment for Substance Misuse and Mental Illness, 15 J. HEALTH CARE L. \& POL'y 75, 90 (2012) (discussing "statutory exceptions to the default rule"); Kerwin et al., supra note 296, at 16-17 tbl.1; Tori Lallemont, Anna Mastroianni \& Thomas M. Wickizer, Decision-Making Authority and Substance Abuse Treatment for Adolescents: A Survey of State Laws, 44 J. AdOLESCENT HeAlTH 323, 323 (2009) (discussing how "[s]ome states have carved out exceptions" to the doctrine of parental consent). States vary in the ages at which minors can consent to substance abuse treatment independently, as well as whether confidentiality is promised. Kerwin et al., supra note 296, at 16-17 tbl.1; Pedro Weisleder, Inconsistency Among American States on the Age at Which Minors Can Consent to Substance Abuse Treatment, 35 J. AM. ACAD. PSYCHIATRY \& L. 317, 319 (2007). One survey found that thirty-one states permit a minor of any age to consent to alcohol or drug abuse treatment, while another additional thirteen states permit minors of specified ages to obtain such services without parental consent. Boldt, supra, at 90-92.

298 See, e.g., Miss. CODE ANN. § 41-41-14 (West, Westlaw through 2019 Regular Sess.) (authorizing health care professionals to consult with or provide medications to minors age fifteen or older seeking services for mental health or substance abuse without parental consent); OR. REV. STAT. § 109.675 (West, Westlaw through 2018 Regular Sess. and 2018 Special Sess. of the 79th Legislative Assembly) (same at age fourteen).

${ }^{299}$ Ray Glier, Seeking Mental Health Support: Teens Help Pass New Law to Access Mental Health Care Without Parental Consent, YouTH TODAY (Mar. 14, 2016), https://youthtoday.org/2016/03/ seeking-mental-health-support-teens-helped-pass-new-law-to-access-mental-health-care-withoutparental-consent/ (reporting that the New Jersey legislature initially passed a bill authorizing minors' independent access to mental health treatment for minors age thirteen and older but amended the bill when former Governor Chris Christie refused to sign the bill without the revision). Some statutes contain additional conditions related to the minor's maturity or the potentially detrimental effects of denying treatment. See, e.g., N.Y. MENTAL HyG. § 33.21(c) (McKinney, Westlaw through L.2019, ch. 373). 
ix. Sexual Assault Services

As a society, we are on the cusp of greater legal and social awareness of the traumatic impact of sexual assault on victims. Minors, as well as adults, are victims of such assaults: "One third of all victims of sexual assault reported to law enforcement agencies are adolescents (13 to 17 years old)." ${ }^{300}$ The impact on victims can be extensive and presents substantial risk to their health and well-being. Victims may experience a range of physical injuries. ${ }^{301}$ In addition, rape of female adolescents is associated with a myriad of psychosocial effects, such as depression, eating disorders, and other mental health problems and suicidal ideation or attempts. ${ }^{302}$ Minors' access to intervention is important for the diagnosis and treatment of the effects of the assault on the victim and to enable the criminal justice system to apprehend the perpetrator and achieve important social goals of deterrence and promoting public safety. Sexual assault services involve not only diagnostic and treatment interventions, but forensic evaluation to assist law enforcement: "Sexual assault treatment generally consists of a medical history, a physical examination, an anogenital examination, testing and prophylaxis for HIV and sexually transmitted diseases, emergency contraception, pregnancy testing and counseling, treatment for any other injuries, rape crisis counseling, referrals for additional services and the collection of forensic evidence." 303

Laws specifically addressing minors' independent access to sexual assault related services are relatively new. Illinois law provides an example:

Where a minor is the victim of a predatory criminal sexual assault of a child, aggravated criminal sexual assault, criminal sexual assault, aggravated criminal sexual abuse or criminal sexual abuse ... the consent of the minor's parent or legal guardian need not be obtained to authorize . . . medical personnel to furnish health care services or counseling related to the diagnosis or treatment of any disease or injury arising from such offense. The minor may consent to such counseling,

300 Jeffrey S. Jones et al., Comparative Analysis of Adult Versus Adolescent Sexual Assault: Epidemiology and Patterns of Anogenital Injury, 10 ACAD. EMERGENCY MED. 872, 872 (2003).

${ }^{301} \mathrm{Id}$. at 876 .

302 "Studies of female adolescents have found rape during childhood or adolescence to be associated with increased risky behaviors and mental health problems, including younger age of first voluntary intercourse; higher rates of depression, including suicidal ideation/attempts; and other self harm behaviors such as self-mutilation and eating disorders." Miriam Kaufman, Care of the Adolescent Sexual Assault Victim, 122 PEDIATRICS 462, 464 (2008).

${ }^{303}$ Jessica Feierman et al., N.Y. Civil Liberties Union, TeEnagers, Health Care \& the LAW: A Guide TO THE LAW ON MinORS’ Rights IN NEW York STATE 93, 93 n.149 (2d ed. n.d.). 
diagnosis or treatment as if the minor had reached his or her age of majority .... ${ }^{304}$

Similarly, Maryland's statutes provide that a minor has the same capacity to consent as an adult to "Physical examination and treatment of injuries from an alleged rape or sexual offense; ... Physical examination to obtain evidence of an alleged rape or sexual offense." 305 While statutes as specific as those of Illinois and Maryland may not exist in all states, authors have noted that the range of services required to respond adequately to a sexual assault may fall within several of the other exceptions to the parental consent doctrine already on the books, such as exceptions for STI testing and treatment, family planning, mental health counseling, and emergency medical services. ${ }^{306}$ Therefore, medical professionals working with minor victims of sexual assault generally take advantage of the range of exceptions available under the law to provide the wide range of services necessary to assist these victims without requiring parental consent. ${ }^{307}$

Clearly, the interests of the minor in receiving needed medical and psychological care are weighty, as are the state's interests in facilitating that care and pursuing its law enforcement objectives. In light of the sensitive nature of this type of assault, minors would be less likely to seek services if parental consent was required. Indeed, in some instances, parents or other family members perpetrated the assault. Confidentiality of services is also strongly recommended by practitioners, in that fear of disclosures to parents may discourage many adolescents from seeking help.

The analyses above reveal the strong policy interests in facilitating minors' access to the services that are the subject of the statutory exceptions to the doctrine of parental consent. In each case, a requirement for parental consent presents barriers to many minors who need access to services. In light of the sensitive or controversial nature of the services or the activities leading to the need, it is understandable that many minors are hesitant to involve their parents. It is not relevant whether a minor's reluctance to disclose her need for medical services is accurate in its prediction of a likely punitive or obstructive parental response. If the minor believes that a nonsupportive parental response will follow such disclosure, the minor will be deterred from involving her parents. In such cases, whether or not there exists a true conflict of interests between the minor and the parent, parents are not situated to be able to act in their minor children's best interests.

\footnotetext{
${ }^{304} 410$ ILL. COMP. STAT. ANN. 210/3(b) (West through P.A. 101-115).

${ }^{305}$ MD. CODE ANN., HEALTH-GEN. § 20-102(c) (West, Westlaw through 2019 Regular Sess. of the General Assembly).

${ }^{306}$ FEIERMAN ET AL., supra note 303, at 41-42, 57, 62.

${ }^{307}$ See generally id. at 37-63 (describing the types of care minors can receive without parental consent, and, in those situations, what New York State agencies require of hospitals and physicians, for instance when they treat a rape survivor or receive the results of a positive HIV test).
} 
Furthermore, as noted with respect to many of the exceptions above, there are concerns among medical professionals and minors that legal authority for independent access to services for minors is an illusory right without a guarantee of confidentiality. As we discuss in Part III below, access to childhood vaccines by minors whose parents have failed to vaccinate them presents issues analogous to those raised for access to services related to contraception, prenatal care, abortion, STDs, mental health and substance abuse, and sexual assault. Therefore, we recommend that a legislative exception to the doctrine of parental consent for childhood vaccinations should be enacted by the fifty states and the District of Columbia.

\section{INDEPENDENT AND CONFIDENTIAL ACCESS BY ADOLESCENTS TO ChILdHOOd VACCINES: MEDICAL, LEGAL, PSYCHOLOGICAL, AND POLICY ISSUES}

In Part II, we analyzed the justifications for the most common statutory exceptions to the doctrine of parental consent across the United States. In this Part, we demonstrate that, in light of recent patterns of parental refusal to consent to medically necessary vaccinations for their minor children, minors' independent access to such vaccines is one of several policy responses necessary to promote the health of unvaccinated minors and the general public.

\section{A. The Necessity of an Exception to the Doctrine of Parental Consent}

\section{The Childhood Vaccination Crisis}

Patterns of parental childhood vaccine refusal have led to clusters within communities with low vaccination rates which have, in turn, led to increases in the rates of disease. By mid-year in 2019, the rate of measles had surpassed the highest annual rate since $1992 .{ }^{308}$ Most of the victims of the outbreaks were unvaccinated children in communities with low vaccination rates. For example, in a large outbreak in Rockland County, New York, $80.4 \%$ of the 312 cases reported as of September 25, 2019 were persons under age eighteen, $79.5 \%$ had not received any MMR inoculations. ${ }^{309}$ Only $3.2 \%$ of those infected had been fully vaccinated with the MMR. There was a direct relationship between parental failure to vaccinate their children and this and other outbreaks. The rates of vaccination are dangerously low in some geographical areas, with numbers of unvaccinated children continuing

\footnotetext{
308 Measles Cases and Outbreaks, CENTERS FOR DISEASE CONTROL \& PREVENTION, https://www.cdc.gov/measles/cases-outbreaks.html (last reviewed Oct. 11, 2019).

3092018 - 2019 Measles Outbreak in Rockland County, COUNTY RocKLAND, http://rocklandgov.com/departments/health/measles-information/ (last visited June 19, 2020).
} 
to increase. ${ }^{310}$ In light of these factors, the state's interest in increasing vaccination rates to protect the public's health is exceedingly strong.

\section{The Convergence of State and Child Interests in Immunization from Vaccine-Preventable Diseases}

As noted above, state childhood vaccination mandates serve not only the state's police power interest in protecting public health, but also its parens patriae interest in promoting the health of the vaccinated children. States have allowed parents to refuse vaccinations under limited circumstances. ${ }^{311}$ The existence of those exemptions, however, reflects a concession by policymakers to the competing interests of parents in making health care choices for their children and in practicing religions - the teachings of which are inconsistent with compliance with state vaccine mandates. These concessions, however, do not reflect a dilution of the state's strong legislative intent to protect the public and individual children from vaccine-preventable diseases through high rates of vaccination of the student population. ${ }^{312}$ And, indeed, with recent increases in non-vaccination rates, several states that have experienced outbreaks of vaccine-preventable diseases have restricted or eliminated nonmedical exemptions. ${ }^{313}$ Clearly these state legislatures have determined that, as the risks to public health increase, parental discretion must be limited to the extent necessary to contain the spread of infectious diseases. ${ }^{314}$

Until recently, the number of parents refusing vaccinations was sufficiently low that herd immunity protected children whose parents intentionally refused immunization and persons who cannot be vaccinated due to age or medical contraindication. Thus, exemption from vaccine requirements did not, in the past, measurably risk the welfare of the unvaccinated minors or others in the community. Yet, in recent years, public

${ }^{310}$ Holly A. Hill, Vaccination Coverage Among Children Aged 19-35 Months - United States, 2017, 67 MORBIDITY \& MORTALITY WKLY. REP. 1123, 1126-27 (2018).

${ }^{311}$ See Reiss \& Weithorn, Responding to the Childhood Vaccination Crisis, supra note 7, at 915 19 (summarizing and discussing the pattern of statutory exemptions that exist across the states). See also States with Religious and Philosophical Exemptions from School Immunization Requirements, NAT'L CONF. ST. LEGISLATURES (June 14, 2019), http://www.ncsl.org/research/health/school-immunizationexemption-state-laws.aspx (summarizing state vaccination exemption policies).

${ }^{312}$ In addition, the existence of exemptions does not reveal any legislative position on whether teens who seek to comply with governmental vaccination recommendations should be able to do so. With the exception of those instances cited within, legislatures have not previously addressed the question of minors' legal authority to consent to childhood vaccinations. See supra notes 20-24.

313 See Neal D. Goldstein, Joanna S. Suder \& Jonathan Purtle, Trends and Characteristics of Proposed and Enacted Legislation on Childhood Vaccination Exemption, 2011-2017, 109 AM. J. PUB. HEALTH 102, 104-06, 105 tbl.2 (2019) (summarizing bills enacted between 2011 and 2017).

${ }^{314}$ Some scholars recommend that all states follow this lead. See, e.g., Chemerinsky \& Goodwin, supra note 140, at 589 (proposing elimination of all nonmedical vaccination law exemptions); Mark Fadel, 360 Years of Measles: Limiting Liberty Now for a Healthier Future, 39 J. LEGAL MED. 1, 1, 13 (2019) (same). 
health experts have expressed concerns that herd immunity is gradually weakening as the number of unvaccinated persons increases, particularly in certain geographic locales where there are large clusters of unvaccinated children. ${ }^{315}$ Thus, the threat to the public's health from a continuation of the current non-vaccination trends is real, as are the dangers to each individual unvaccinated child. As we have noted elsewhere, the state's police power and parens patriae interests are to some extent additive, resulting in a formidable, although not unlimited, grant of state authority that can, in some circumstances, override traditional deference to parental discretion, as in the case of laws regulating compulsory education and child labor, child protection laws, and states' mandatory vaccination laws. ${ }^{316}$

The state's interests also converge with the interests of minors who wish to be vaccinated despite parental objection. ${ }^{317}$ Children have independent

${ }^{315}$ For example, in a recent article, several authors, including Anthony S. Fauci, Director of the National Institute of Allergy and Infectious Diseases of the National Institutes of Health, expressed concerns about the risks to persons in those population subgroups who cannot be immunized and were previously protected by herd immunity:

\begin{abstract}
The greatest risk of measles-related complications occurs in immunosuppressed people. This population may have atypical presentations with severe complications that have not been documented in immunocompetent patients, such as giant-cell pneumonia and measles inclusion-body encephalitis. Exposure to measles in people with HIV infection has led to serious complications and even death. Higher rates of measles complications and deaths have also been reported in patients with cancer, patients with solid organ transplants, people receiving high-dose glucocorticoids, and those receiving immunomodulatory therapy for rheumatologic disease. People with profound immunosuppression cannot be safely vaccinated with the live-attenuated vaccine and must rely on herd immunity to protect them from measles infection.
\end{abstract}

Exposure to measles in the community certainly represents a danger to high-risk persons during a local outbreak; however, nosocomial transmission may pose an even greater threat and has been reported throughout the world. For example, during a measles outbreak in Shanghai in 2015, a single child with measles in a pediatric oncology clinic infected 23 other children, more than $50 \%$ of whom ended up with severe complications, and the case fatality rate was $21 \%$. When the umbrella of herd immunity is compromised, such populations are highly vulnerable.

Catherine I. Paules, Hilary D. Marston \& Anthony D. Fauci, Measles in 2019-Going Backward, 380 NEW ENG. J. MED. 2185, 2187 (2019) (citations omitted). See also Robert A. Bednarczyk, Walter A. Orenstein \& Saad B. Omer, Estimating the Number of Measles-Susceptible Children and Adolescents in the United States Using Data from the National Immunization Survey-Teen (NIS-Teen), 184 AM. J. EPIDEMIOLOGY 148, 154 (2016) (reporting that, while national levels of immunization at the time of their study were still at or higher than the threshold of $92 \%$, the level needed to sustain herd immunity, the numbers and patterns of clustering of nonvaccination could lead to circumstances in which herd immunity may not protect some segments of the population); Jacqueline K. Olive et al., The State of the Antivaccine Movement in the United States: A Focused Examination of Nonmedical Exemptions in States and Counties, 15 PLOS MED., June 2018, at 1, 7 (2018) (warning of the existence of a hotspot vulnerable to outbreaks because of high rates of exemptions from vaccines requirements).

${ }^{316}$ Reiss \& Weithorn, Responding to the Childhood Vaccination Crisis, supra note 7, at 913-14.

${ }^{317}$ See supra notes $178-82$ and accompanying text. 
interests in avoiding serious illness, disability, and death. ${ }^{318}$ Where a medically recommended high benefit/low risk intervention is available to protect the minor's health, the minor's interest in receiving that intervention over parental objection is substantial. That interest becomes even weightier when parents choose to rely on misinformation and myths in the exercise of their parental decisionmaking authority, denying minors interventions endorsed universally by medical experts. Minors' interests in protecting their own health and that of others outweigh parental authority to endanger their children's and the public's health through vaccine refusal, particularly when aligned with the interests of the state.

We do not espouse wholesale rejection of the doctrine of parental consent. Each treatment context in which the state or a minor seeks an exception from the doctrine must be evaluated on its own merits. Thus, our proposal does not extend beyond the instant case. We recognize that questions about minors' best interests in the medical context are complex, and that what specifically is in any child's best interests might be indeterminate or unknowable without hindsight. And even where outcomes are certain, reasonable minds may differ as to what is "best" in many situations. $^{319}$ Yet, this lack of clarity does not characterize decisions to accept the recommended childhood vaccinations. Indeed, these vaccinations provide the quintessential example of a high benefit/low risk intervention supported by a near-universal medical consensus. Thus, we need not confront many of the thorny ethical analyses inherent in allocations of decisionmaking authority among disputing parties when questions of children's medical best interests are at issue. ${ }^{320}$ Indeed, the

${ }^{318}$ See supra notes $178-87$ and accompanying text.

${ }^{319}$ See, e.g., Newmark v. Williams, 588 A.2d 1108, 1110, 1120 (Del. 1991) (declining to override parental decisionmaking authority on the basis that parents who rejected treatment were acting in the child's best interests, even though the parental decision would likely result in the child's death within six to eight months, where recommended treatment for the child's cancer had a $40 \%$ chance of success, but entailed substantial risks and discomforts, and could itself cause death).

${ }^{320}$ In recent decades, pediatric bioethicists and other scholars have contributed substantially to debates about the meaning of the best interests standard in the context of medical treatment of children. For example, Loretta M. Kopelman provides an overview of the best interests standard, discussing the differences among the versions of the standard applied by clinicians, philosophers, and policy makers. Loretta M. Kopelman, The Best-Interests Standard as Threshold, Ideal, and Standard of Reasonableness, 22 J. MED. \& PHIL. 271, 272-73 (1997). Some scholars have argued for rejection of the best interest standard. See, e.g., Erica K. Salter, Deciding for a Child: A Comprehensive Analysis of the Best Interest Standard, 33 THEORETICAL MED. \& BiOETHICS 179, 180 (2012). Douglas Diekema has written a number of articles arguing that the "harm principle" - that is, that "state intervention should not be trivial but should be triggered when a parental decision places the child at significant risk of serious harm") —-should replace the best interest standard, see, e.g., Douglas S. Diekema, Parental Refusals of Medical Treatment: The Harm Principle as Threshold for State Intervention, 25 THEORETICAL MED. \& BIOETHICS 243, 252 (2004) (introducing the "harm principle"); Douglas S. Diekema, Revisiting the Best Interest Standard: Uses and Misuses, 22 J. CLINICAL ETHICS 128, 128 (2011) (defending the "harm principle" as superior to the best interest standard). In a recent issue of the American Journal of Bioethics, several scholars further elaborated on the advantages of the best interest standard, see, e.g., Johan Christiaan Bester, The 
ACIP-recommended vaccinations provide the quintessential example of a high benefit/low risk intervention.

Parental choices to rely on misinformation about vaccines and mistrust of the medical profession, or to privilege personal philosophical or religious beliefs over the welfare of their children and the community, should not be given legal effect in light of the risks to unvaccinated children and the general public. Consistent with the Court's assertion in Prince, parental rights do "not include liberty to expose the community or the child to communicable disease or the latter to ill health or death." 321

The current balance of interests requires new legal solutions. States must consider policies to increase rates of parental compliance with mandatory vaccination laws. ${ }^{322}$ In addition, where reliance on the doctrine of parental consent fails adequately to protect the welfare of minors and presents a danger to the public health, alternate decisional mechanisms must be considered. We propose one such mechanism below.

\section{The Nature of Parental Opposition to Vaccinations Creates Challenging Barriers to Care}

The growing literature analyzing the vehement opposition that many parents demonstrate to childhood vaccinations ${ }^{323}$ reveals that this phenomenon presents particularly challenging barriers to care. While some parents may be only "vaccine-hesitant," others may be "vaccine-rejecting,"

Harm Principle Cannot Replace the Best Interest Standard: Problems with Using the Harm Principle for Medical Decision Making for Children, 18 AM. J. BIOETHICS 9, 10 (2018) (providing a bioethical analysis favoring retention of the best interest standard); Thaddeus Mason Pope, The Best Interest Standard for Health Care Decision Making: Definition and Defense, 18 AM. J. BIOETHICS 36, 36 (2018) (supplementing Bester's argument with a legal analysis favoring the best interest standard).

${ }^{321}$ Prince v. Massachusetts, 321 U.S. 158, 166-67 (1944).

${ }^{322}$ Reiss \& Weithorn, Responding to the Childhood Vaccination Crisis, supra note 7, at 1611-15.

${ }^{323}$ See, e.g., Amin et al., supra note 95, at 874, 877 (detailing the results of a study finding that endorsement of harm and fairness ideas do not predict parental vaccine hesitancy); Gabriela Capurro et al., Measles, Moral Regulation and the Social Construction of Risk: Media Narratives of "Anti-Vaxxers" and the 2015 Disneyland Outbreak, 43 CANADIAN J. SOC. 25, 40-42 (2018) (discussing the skewed media presentation of "anti-vaxxer" and "vaccine hesitant" parents in light of the 2015 Disneyland measles outbreak); Matthew Motta, Timothy Callaghan \& Steven Sylvester, Knowing Less but Presuming More: Dunning-Kruger Effects and the Endorsement of Anti-Vaccine Policy Attitudes, 211 SOC. SCI. \& MED. 274, 274-75 (2018) (detailing the results of study that found that Dunning-Kruger effects explain vaccination opposition); Glen J. Nowak \& Michael A. Cacciatore, Parents' Confidence in Recommended Childhood Vaccinations: Extending the Assessment, Expanding the Context, 13 HuM. VACCINES \& IMMUNOTHERAPEUTICS 687, 695-97 (2017) (discussing a study that examined confidence ratings and parental behavior towards vaccination); Gregory A. Poland, Jon C. Tilburt \& Edgar K. Marcuse, Preserving Civility in Vaccine Policy Discourse: A Way Forward, 322 JAMA 209, 209-10 (2019) (advocating for principled pluralism to restore civility to the vaccination discussion); Aaron Rothstein, Vaccines and Their Critics, Then and Now, 44 NEW ATLANTIS 3, 8-11 (2015) (overviewing the history and evolution of anti-vaccination movements). 
that is, "adamant in their refusal to consider vaccination for their children." 324 Hagood and Herlihy indicate that, in the cases of these parents:

[S]uch rejection may not be based upon previous history of a vaccine-related adverse event, or actual medical contraindication to vaccination, either for themselves or for their children. [Vaccine-rejector] parents may express beliefs that vaccines cause more harm than good, or that vaccines are a plot of a conspiracy involving governments, health organizations and pharmaceutical companies. They commonly express beliefs in other conspiracy theories as well. These belief systems indicate a lack of truth in public institutions and "allopathic" medicine. Therefore, [vaccine-rejector] parents are more likely to utilize so-called "complementary" or "alternative" medical practices, and are least likely to receive regular care in a pediatrician's office. Thus, they are least likely to be open to education on the issue due to their irrational belief systems. ${ }^{325}$

Parents who hold such strong beliefs are likely to see their minor child's desire to be vaccinated in an extremely negative light. Adolescents will no doubt be well aware of their parents' viewpoints and the futility of any attempt to persuade their parents to allow them to be vaccinated. Indeed, the parents' refusal to vaccinate their children in prior years-contravening governmental policy and the social consensus favoring vaccinationprovides strong evidence that the parents would refuse to consent to vaccinations upon a request from their children. ${ }^{326}$

Furthermore, minors may reasonably fear other negative repercussions from an expression of interest in being vaccinated, ranging from tension and conflict in the parent-child relationship, parental actions to prevent the minor from taking steps to become vaccinated, punitive consequences for the minor or, in extreme cases, abuse directed at the minor. ${ }^{327}$ Minors'

${ }^{324}$ E. Allison Hagood \& Stacy Mintzer Herlihy, Addressing Heterogeneous Parental Concerns About Vaccination with a Multiple-Source Model: A Parent and Educator Perspective, 9 HuM. VACCINES \& IMMUNOTHERAPEUTICS 1790, 1791 (2013).

${ }^{325} I d$. (citations omitted).

${ }^{326}$ It is possible that some parents whose children are unvaccinated or who have received only some of the full series of recommended vaccines are not actively opposed to vaccinations but have simply not made the effort to complete the series. In those cases, parents may be willing to consent if their children request vaccination. Yet, as states tighten standards and procedures for vaccination exemptions, see Reiss \& Weithorn, Responding to the Childhood Vaccination Crisis, supra note 7, at 918-19, the effort required to obtain exemptions will exceed the inconvenience of obtaining vaccinations, making it more and more likely that parental failure to fully vaccinate their children reflects intentional rejection of state requirements.

${ }^{327}$ While we are speculating that in rare cases such abuse might occur, we draw this inference from the occasional incidents in which those opposing vaccinations have threatened violence against scholars 
knowledge of the fervent nature of their parents' anti-vaccine attitudes may deter them from broaching the topic at all. Based on the zealousness with which many vaccine-rejecting parents advocate their viewpoints, we do not second-guess the wisdom of such cautiousness. Indeed, we argue that the nature of some parents' strongly held opposition to recommended childhood vaccinations parallels parental opposition to abortion and other activities implicated by the "sensitive" health care interventions just discussed. While immunization for vaccine-preventable diseases does not fall within one of the traditional categories of behavior or treatment typically characterized as "sensitive," the barriers to care are analogous. A minor's expression of preferences inconsistent with parental viewpoints about vaccinations are likely to be treated as taboo in households headed by vaccine-opposing parents. A minor seeking immunization may be perceived as violating family values and norms. Children reasonably may worry that expression of disagreement with their parents on this matter will lead to rebuke by, or chastisement from, parents and obstruction of subsequent attempts to access vaccines.

\section{B. Statutory Authorization of Adolescents' Independent Consent for Childhood Vaccinations}

A statutory exception to the doctrine of parental consent, authorizing older minors independently and confidentially to access state-mandated childhood vaccinations, constitutes an important addition to the range of legal responses states are implementing to confront the high rates of nonvaccination within their populations. Access to childhood immunization for vaccine-preventable diseases is justified by the same factors that legitimize state empowerment of minors to provide independent consent in the context of the other statutory exceptions, bearing the strongest analogy to treatment for STDs. In both cases, the medical intervention seeks to protect minors from infectious diseases that present substantial risk to health and life. Furthermore, in both cases, infection of the minor presents immediate and serious dangers to others who might be exposed to the disease.

\section{Competence to Make Health Care Decisions}

According to legal principles in the fifty states, practitioners generally do not have legal authority to treat a patient unless that patient provides informed consent. In order to be legally valid, a patient's health care

and others who promote policies consistent with ACIP and CDC vaccination recommendations. See, e.g., Meredith Wadman, Vaccination Opponents Target CDC Panel, 363 SCIENCE 1024, 1024 (2019), https://science.sciencemag.org/content/363/6431/1024.summary; Nina Shapiro, Vaccine Proponents Receive Death Threats. Again., FORBES (July 22, 2019), https://www.forbes.com/sites/ninashapiro/ 2019/07/22/vaccine-proponents-receive-death-threats-again. 
decisions must be informed, competent, and voluntary. ${ }^{328}$ The requirement that consent be informed imposes on health care practitioners the duty to disclose to prospective patients the information necessary to make the treatment decisions. That information should describe, consistent with the best available knowledge, and in a manner comprehensible to the patient: (1) the nature of the condition, illness, disorder, or symptom for which treatment is recommended; (2) the likely consequences of failure to treat the condition, illness, disorder, or symptom; (3) the nature of each alternative treatment; (4) the possible benefits, risks, discomforts, and side effects of each of the alternative treatments and their anticipated likelihood; and (5) the treating practitioner's recommendation among the treatment alternatives and its rationale. ${ }^{329}$ The patient must be competent, that is, have the capacity to understand and, according to some standards, also to reason about, or appreciate the implications of, the information provided. Finally, patients' decisions regarding treatment must be made voluntarily, that is, at a minimum, free from coercive or controlling influences, in order to be legally valid. $^{330}$

Beginning in the 1970s, researchers have engaged in empirical work conceptualizing, operationalizing, and evaluating competence to make treatment decisions. ${ }^{331}$ This work was advanced substantially by the creation of the MacArthur Foundation Network on Treatment Competence. Building on the earlier research, that group developed standards for assessment of

\footnotetext{
${ }^{328}$ Alan Meisel, Loren H. Roth \& Charles W. Lidz, Toward a Model of the Legal Doctrine of Informed Consent, 134 AM. J. PSYCHIATRY 285, 286-87 (1977).

329 This summary consolidates themes drawn from legal, bioethical, and medical guidelines. See, e.g., Code of Medical Ethics Opinion 2.1.1, AM. MED. Ass'N: INFORMED CONSENT, https://www.amaassn.org/delivering-care/ethics/informed-consent (last visited Mar. 17, 2020) (indicating that the physician should inform the patient of " 1 . The diagnosis (when known)[;] 2. The nature and purpose of recommended interventions[;] 3. The burdens, risks, and expected benefits of all options, including forgoing treatment"); TOM L. BEAUCHAMP \& JAMES F. CHILDRESS, PRINCIPLES OF BIOMEDICAL ETHICS 121-22 (6th ed. 2009); Meisel, Roth \& Lidz, supra note 328, at 286-87 (describing the three elements of informed consent); Alan Meisel \& Lisa D. Kabnick, Informed Consent to Medical Treatment: An Analysis of Recent Legislation, 41 U. PITT. L. REV. 407, 421-38 (1980); Alan Meisel, The "Exceptions" to the Informed Consent Doctrine: Striking a Balance Between Competing Values in Medical Decisionmaking, 1979 WIS. L. REV. 413, 418.

${ }^{330}$ See Paul S. Appelbaum, Charles W. Lidz \& Robert Klitzman, Voluntariness of Consent to Research: A Conceptual Model, 39 HASTINGS CTR. REP. 30, 30 (2009) (analyzing the meaning of the voluntariness requirement); Robert M. Nelson et al., The Concept of Voluntary Consent, 11 AM. J. Bioethics 6, 6 (2011) (same).

331 See, e.g., Paul S. Appelbaum, Charles W. Lidz \& Alan Meisel, Informed Consent: LEgal TheORY AND CliniCAL PRACTICE 3-4 (1987); ChARLES W. LIDZ ET AL., INFORMED CONSENT: A Study of Decisionmaking IN Psychiatry 3-9 (1984); Loren H. Roth, Alan Meisel \& Charles W. Lidz, Tests of Competency to Consent to Treatment, 134 AM. J. PSYCHIATRY 279, 280 (1977); Lois A. Weithorn \& Susan B. Campbell, The Competency of Children and Adolescents to Make Informed Treatment Decisions, 53 CHILD DEV. 1589, 1595 (1982).
} 
competence $^{332}$ that have had substantial influence in law, scholarship, and medical practice. Scholars and researchers today generally recognize that the following standards of competence are core components of modern assessments of treatment decisionmaking capacity, although statutory or case law definitions of competence may emphasize some, but not all, as required in particular contexts: (1) ability to communicate a choice (that is, "[c]learly indicate a preferred treatment option"); (2) ability to understand relevant information (that is, "[g]rasp the fundamental meaning of information communicated by" the practitioner); (3) ability to reason about treatment options (i.e., "engage in a rational process of manipulating the relevant information"); and (4) ability to appreciate the situation and its likely consequences (that is, "acknowledge medical condition and likely consequences of treatment options"). ${ }^{33}$

The four standards do not always appear in all legal definitions of competence. Most commonly, statutes will incorporate a focus on patient understanding of the information provided by the practitioner and communication of a treatment preference. For example, California-by statute - defines treatment decisionmaking capacity as "a person's ability to understand the nature and consequences of a decision and to make and communicate a decision, and includes in the case of proposed health care, the ability to understand its significant benefits, risks, and alternatives." Yet, some statutes identify understanding and appreciation (of the consequences of the proposed surgical or medical treatment or procedures), while still others also incorporate a reasoning standard (such as "weigh risks and benefits" of the options and their likely consequences). ${ }^{335}$ The

332 See Thomas Grisso \& Paul S. ApPelbaum, Assessing COMPETEnCE to Consent TO

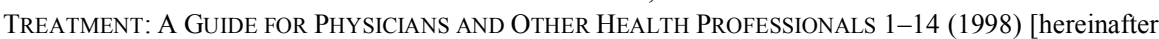
Grisso \& Appelbaum, Assessing Competence]; Paul S. Appelbaum, Assessment of Patients' Competence to Consent to Treatment, 357 NEw ENG. J. MED. 1834, 1834 (2007) [hereinafter Appelbaum, Assessment]; Paul S. Appelbaum \& Thomas Grisso, The MacArthur Treatment Competence Study. I: Mental Illness and Competence to Consent to Treatment, 19 LAW \& HuM. BEHAV. 105, 106 (1995) [hereinafter MacArthur I] (discussing the changes in medicine and law in response to mental illness); Jessica Wilen Berg, Paul S. Appelbaum \& Thomas Grisso, Constructing Competence: Formulating Standards of Legal Competence to Make Medical Decisions, 48 RUTGERS L. REV. 345, 348 (1996); Thomas Grisso et al., The MacArthur Treatment Competence Study. II: Measures of Abilities Related to Competence to Consent to Treatment, 19 LAW \& HUM. BEHAV. 127, 128 (1995) [hereinafter MacArthur II]; Thomas Grisso \& Paul S. Appelbaum, The MacArthur Treatment Competence Study. III: Abilities of Patients to Consent to Psychiatric and Medical Treatments, 19 LAW \& HuM. BEHAV. 149, 150 (1995) [hereinafter MacArthur III] (explaining the results). See also The MacArthur Treatment Competence Study: Executive Summary, MacArthur Res. NeTwOrK ON MENTAL HeALTH \& L., http://www.macarthur.virginia.edu/treatment.html\#N_1_(last updated May 2004).

333 GRISSO \& APPELBAUM, ASSESSING COMPETENCE, supra note 332, at 31-60; Appelbaum, Assessment, supra note 332, at 1836 tbl.1; see also MacArthur I, supra note 332, at 108-11.

${ }^{334}$ CAL. PROB. CODE $§ 4609$ (West, Westlaw through 2019 Regular Sess. ch. 524).

${ }^{335}$ For example, the competence concepts defining "maturity" for the purpose of the mature minor rule appear in statute or case law as follows: ARK. CODE ANN. § 20-9-602(7) (West, Westlaw through 2019 Regular Sess. of the 92d Arkansas General Assembly) (authorizing “[a]ny unemancipated minor of 
MacArthur group also developed standardized measures that can be used by health care practitioners ${ }^{336}$ or researchers. ${ }^{337}$ The measures allow evaluators to customize the assessment of capacity for each treatment or research decisionmaking context.

Scholarship considering minors' competence to make treatment decisions generally falls within two categories: (1) analyses of basic research on children's development and maturation, cognitive functioning, socioemotional functioning, and other domains potentially relevant to capacity as defined by one or more legal standards; and (2) reports of empirical studies designed to measure children's treatment decisionmaking competence, particularly in comparison with adults, by evaluating functioning relative to one or more legal standards of competence. Both sets of studies are important. The former category identifies and describes the domains and patterns of development that change over time, and how various factors affect their expression and maturation as children develop into adults. The latter category focuses specifically on assessment of minors' capacities according to the legal tests identified above, ensuring that the skills and abilities measured are those that are criterion-relevant. Indeed, one of the most important contributions of the past several decades of research on legal competencies is the core principle that it is necessary to operationalize or translate the relevant legal tests into an assessment strategy or tool that allows measurement of the functional abilities specified by the applicable legal standard. ${ }^{338}$

Capacity or competence to make treatment decisions ${ }^{339}$ is one of several types of functional abilities that may be of relevance to the law regulating

sufficient intelligence to understand and appreciate the consequences of the proposed surgical or medical treatment or procedures" to consent to such medical or surgical care "for himself or herself"); In re Swan, 569 A.2d 1202, 1205 (Me. 1990) (holding that a minor has capacity to consent or refuse treatment when "the minor has the ability of the average person to understand and weigh the risks and benefits" and "if he is capable of appreciating the nature, extent, and probable consequences of the conduct consented to" (citation omitted)).

${ }^{336}$ Thomas Grisso \& PAul S. ApPelbaum, MacArthur COMPETENCE ASSESSMENT TOOL FOR TREATMENT (MACCAT-T) 1-2 (1998).

${ }^{337}$ Paul S. ApPelbaum \& Thomas Grisso, The MacArthur Competence Assessment ToOL FOR CLINICAL RESEARCH (MACCAT-CR) 1-4 (2001).

338 ThOMAs GRISSO, EVAluATING COMPETENCIES: ForENSIC ASSESSMENTS AND INSTRUMENTS 404-60 (2d ed. 2003) [hereinafter Grisso, EvALUATING COMPETENCIES].

339 The terms "capacity" and "competence," in theory, have slightly different meanings in this context. Lois A. Weithorn, Psychological Distress, Mental Disorder, and Assessment of Decisionmaking Capacity Under U.S. Medical Aid in Dying Statutes, 71 HastingS L.J. 637, 641 \& n.10 (2020) [hereinafter Weithorn, Aid in Dying Statutes]. One set of authors characterized the distinction: "Capacity' refers to abilities relevant to performing a task, while 'competency' is a legal judgment that one has sufficient abilities to perform the task." Elyn R. Saks \& Stephen H. Behnke, Competency to Decide on Treatment and Research: MacArthur and Beyond, 10 J. CONTEMP. LEGAL ISSUES 103, 110 (1999). See also GRISSO \& APPELBAUM, ASSESSING COMPETENCE, supra note 332, at 11 ("Most authors distinguish between assessments of decisionmaking capacity, which health care professionals can conduct, and determination of competence, which are legal judgments left to the courts."). Yet, the 
children's lives. ${ }^{340}$ Different legal competencies tap somewhat different skills and abilities, which may mature on different developmental trajectories than other types of competencies of relevance to the law. "Unfortunately, many writers and professionals - including, but not limited to ... policymakers and health care personnel-fail to differentiate among the various legal competencies . . . ."341 Because each type of legal competence is defined by functional criteria relevant to that legal context, assessments of each type of competence must track those situation-specific functional criteria. ${ }^{342}$ Findings of incompetence or competence in one legal sphere do not obviate the necessity to perform focused criterion-relevant assessments of capacity targeted to any other legal question that is of interest. This latter observation is one of several factors explaining why a conclusion that minors in a given age range may be less mature than adults in certain juvenile justice contexts, does not foreclose the question of whether minors in the same age range might be competent to make independent health care decisions. ${ }^{343}$

\section{Psychological and Neuroscientific Developmental Findings Informing Questions About Minors' Capacities to Make Treatment Decisions}

In the 1970s and early 1980s, some scholars focused on the cognitive developmental work of researchers such as Piaget and Kohlberg to hypothesize when children would be able to perform the functions necessary to understand, reason about, and appreciate health care treatment

distinction breaks down in practice, particularly when state policies authorize health care professionals' clinical evaluations of patients' capacity to constitute legally valid judgments. Weithorn, Aid in Dying Statutes, supra, at $641 \mathrm{n} .10$. In such cases, clinicians' determinations of capacity have the effect of legal judgments of competence. GRISSO \& APPELBAUM, ASSESSING COMPETENCE, supra note 332, at 11. It is noteworthy, however, that, in the context of children's legal authority to make health care decisions, the terms capacity and competence are frequently used interchangeably within or across cases, statutes, and scholarly publications.

340 See, e.g., Thomas Grisso, Forensic Evaluation of Juveniles 41-140 (2d ed. 2013); Elizabeth S. SCott \& LAurence Steinberg, Rethinking JuVEnile Justice 118-80 (2008); Lois A. Weithorn, Children's Capacities in Legal Contexts, in ChILDREn, Mental Health, AND THE LaW 25, 49-50 (N. Dickon Reppucci et al. eds., 1984) [hereinafter Weithorn, Children's Capacities in Legal Contexts].

${ }^{341}$ Weithorn, Children's Capacities in Legal Contexts, supra note 340, at 49.

${ }^{342}$ GRISSO, EVAlUATING COMPETENCIES, supra note 338, at 9 ("No single legal criterion or test applies across all legal competencies. Each legal competence refers to somewhat different abilities . . . .). Even beyond the formal legal criteria for each type of competence, there are additional relevant situation-specific factors. Thus, for example, in determinations of competence to make treatment decisions, evaluators must be mindful of the types of information about treatment options that patients must understand and reason about in order to demonstrate competence. For expanded discussion of such additional relevant factors, see, for example, GRISSO \& APPELBAUM, ASSESSING COMPETENCE, supra note 332 , at $21-24$.

${ }^{343}$ See infra notes 356-60 and accompanying text. 
information. ${ }^{344}$ These researchers predicted that minors ages fourteen or fifteen might be able to demonstrate legally valid competence to consent. ${ }^{345}$ As our knowledge of development has itself matured, ultimately incorporating neuroscientific understandings of brain development, together with direct observation of functioning when assessed with attention to the relevant legal standards, discussions about the relevance of these insights for children's capacities in treatment contexts have evolved as well.

Research on brain development has revealed that important neurological maturational changes continue to occur throughout adolescence, and into the early twenties. ${ }^{346}$ We have learned that the "frontal lobes, home to key components of the neural circuitry underlying 'executive functions' such as planning, working memory, and impulse control, are among the last areas of the brain to mature; they may not be fully developed until halfway through the third decade of life." "347 Furthermore, certain "psychosocial characteristics such as impulsivity, sensation seeking, future orientation, and susceptibility to peer pressure" show continued development into young adulthood. ${ }^{348}$ By contrast, however, "the ability of a[] [person] to reason and consider alternative courses of action . . . reaches adult levels during the mid-teen years." ${ }^{449}$ Indeed, researchers have distinguished between "cold" and "hot" cognition. 350 "Cold cognition refers to mental processes (such as working memory or response inhibition) employed in situations calling for deliberation in the absence of high levels of emotion." 351 Generally during circumstances characterized by "cold cognition," minors have relatively unimpeded access to their close-to-adult-like logical reasoning abilities, in that emotional arousal is lower and the wild card of peer influence is minimized. 352 "Hot cognition involves mental processes in affectively charged situations where deliberation is unlikely or difficult." ${ }^{353}$ In these situations, factors such as impulse control and susceptibility to peer influence can interfere with an adolescent's use of his or her reasoning and analytic thinking skills. ${ }^{354}$ Steinberg and others have noted what they refer

${ }^{344}$ Grisso \& Vierling, supra note 136, at 417, 420; Weithorn, Developmental Factors, supra note 136, at 96

${ }^{345}$ See Weithorn, Children's Capacities in Legal Contexts, supra note 340, at 35-38.

${ }^{346}$ See, e.g., Sara B. Johnson, Robert W. Blum \& Jay N. Giedd, Adolescent Maturity and the Brain: The Promise and Pitfalls of Neuroscience Research in Adolescent Health Policy, 45 J. ADOLESCENT HEALTH 216, 216 (2009) (finding that the brain continues to mature after the end of adolescence, justifying a link between neuromaturation and maturity of judgment).

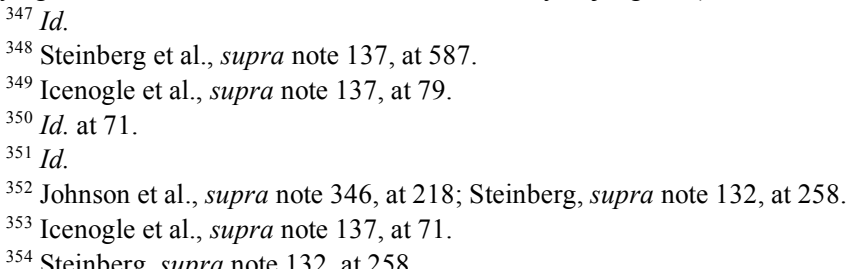


to as a "maturity gap" in the points in development at which individuals are most likely to demonstrate adult-like functioning on tasks invoking cold versus hot cognition. ${ }^{355}$

Researchers have distinguished the contexts in which minors' health care decisions typically occur from those characterizing certain other decisions. ${ }^{356}$ They observe that the competencies needed for medical decisions typically occur in circumstances "where the presence of adult consultants and the absence of time pressure impose sufficient external control to minimize the dangers of impulsive decisionmaking." 357 By contrast, decisions made in the context of criminal behavior, driving, and use of alcohol and drugs, which are often influenced by peers, invoke hot cognition. $^{358}$ Researchers examining the relevant psychological and neuroscientific databases generally predict that minors are capable of making mature health care decisions by adolescence. ${ }^{359}$ Yet, scholars disagree as to the precise ages during adolescence at which minors are likely to be capable of demonstrating adult-like decisionmaking in the cold cognition context of medical care. Some predict that minors as young as eleven or twelve may manifest such capacities, ${ }^{360}$ while others identify ages fifteen or sixteen. ${ }^{361}$ Predictions are just that, of course, and must be further investigated with measures that operationalize the legal standards. It is possible that minors will achieve adult-like levels of capacity at different ages, depending on the standard of competence evaluated. In addition, certain health care treatment situations will present more complex and challenging decisionmaking tasks. Finally, as noted below, depending on the risk-benefit profile of the treatments involved and the range of legal and social factors surrounding the treatment context, policymakers may impose a "sliding scale" of sorts in setting the threshold that separates competence from incompetence, imposing a higher threshold in some situations, and a lower one in others. ${ }^{362}$ Without specification of the relevant standards of competence, the complexity and difficulty of the particular health care decision, and the degree of capacity that must be demonstrated in order to be considered competent, predictions regarding ages at which minors will be capable are necessarily imprecise.

\footnotetext{
${ }^{355}$ Icenogle et al., supra note 137, at 82-83; Steinberg, supra note 132, at 261-65.

${ }^{356}$ Icenogle et al., supra note 137, at 71 (citation omitted).

${ }^{357} \mathrm{Id}$.

${ }^{358} \mathrm{Id}$.

${ }^{359}$ See infra notes 360-62 and accompanying text.

${ }^{360}$ Petronella Grootens-Wiegers et al., Medical Decision-Making in Children and Adolescents: Developmental and Neuroscientific Aspects, 17 BMC PEDIATRICS 120, 126 (2017).

${ }^{361}$ Icenogle et al., supra note 137 , at 80 (citation omitted).

${ }^{362}$ This concept is discussed further below. See infra Part III.B.4.
} 


\section{Empirical Research Examining Children's Capacities to Make Treatment Decisions}

Some researchers have empirically investigated minors' capacities to make treatment decisions by evaluating children's understanding or appreciation of, or reasoning about, hypothetical treatment scenarios or their actual health care situation. ${ }^{363}$ Weithorn and Campbell's 1982 study, and some investigations that have succeeded the MacArthur Treatment Competence Study's work, have incorporated assessment according to the several legal standards emphasized by the MacArthur work. ${ }^{364}$ While some research examined participants' responses to hypothetical medical vignettes in the laboratory, ${ }^{365}$ others evaluated the capacities of participants who were medical patients concerning their own treatment or potential treatment or clinical research protocols. ${ }^{366}$

Those studies that have conducted criterion-relevant assessments in which the measures used track the legal standards that courts and legislators have determined should serve the gatekeeping function when patients' capacities to decide are at issue have not found statistically significant

${ }^{363}$ For reviews of such studies, see EXPERT PANEL WORKING GRP. ON MAID FOR MATURE

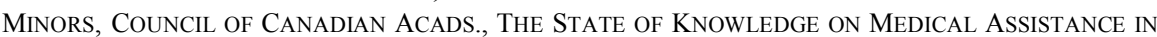
DYING FOR MATURE MINORS (2018), https://cca-reports.ca/wp-content/uploads/2018/12/The-State-ofKnowledge-on-Medical-Assistance-in-Dying-for-Mature-Minors.pdf (summarizing ethical, legal, and clinical perspectives on medical assistance in dying (MAID)); Victoria A. Miller et al., Children's Competence for Assent and Consent: A Review of Empirical Findings, 14 ETHICS \& BEHAV. 255, 255 (2004).

${ }^{364}$ See Tiffany Chenneville et al., Decisional Capacity Among Youth with HIV: Results from the MacArthur Competence Tool for Treatment, 28 AIDS PATIENT CARE \& STDS 425, 426 (2014); Irma M. Hein et al., Why Is It Hard to Make Progress in Assessing Children's Decision-Making Competence?, in IRMA M. HEIN, CHILDREN's COMPETENCE TO CONSENT TO MEDICAL TREATMENT OR RESEARCH 9, 10 (2015), https://pdfs.semanticscholar.org/28c0/43408c5e5ca1f5ce218ed811cf749d16096e.pdf [hereinafter Hein et al., Children's Competence to Consent]; Irma M. Hein et al., Accuracy of the MacArthur Competence Assessment Tool for Clinical Research (MacCAT-CR) for Measuring Children's Competence to Consent to Clinical Research, 168 JAMA PEDIATRICS 1147, 1148 (2014) [hereinafter Hein et al., Accuracy] (assessing competence to consent against legal age standards); Irma M. Hein et al., Feasibility of an Assessment Tool for Children's Competence to Consent to Predictive Genetic Testing: A Pilot Study, 24 J. Genetic Counseling 971, 973 (2015) [hereinafter Hein et al., Feasibility]; Irma M. Hein et al., Informed Consent Instead of Assent Is Appropriate in Children from the Age of Twelve: Policy Implications of New Findings on Children's Competence to Consent to Clinical Research, 16 BMC MED. ETHICS 76, 78-79 (2015) [hereinafter Hein et al., Informed Consent]; Debbie Schachter et al., Informed Consent and Stimulant Medication: Adolescents' and Parents' Ability to Understand Information About Benefits and Risks of Stimulant Medication for the Treatment of Attention-Deficient/Hyperactivity Disorder, 21 J. CHILD \& ADOLESCENT PSYCHOPHARMACOLOGY 139, 146-47 (2011) (discussing capacity to consent in the context of adolescent behavioral disorders); Lois A. Weithorn \& Susan B. Campbell, The Competency of Children and Adolescents to Make Informed Treatment Decisions, 53 CHILD DEV. 1589, 1590 (1982).

${ }^{365}$ Miller et al., supra note 363, at 271; Weithorn \& Campbell, supra note 364, at 1592.

${ }^{366}$ Chenneville et al., supra note 364, at 426; Hein et al., Children's Competence to Consent, supra note 364, at 16; Hein et al., Accuracy, supra note 364, at 1148; Hein et al., Feasibility, supra note 364, at 973; Hein et al., Informed Consent, supra note 364, at 2; Schachter et al., supra note 364, at 140. 
differences between the capacities of adolescents ages fourteen and older and comparison groups of adults. ${ }^{367}$ Weithorn and Campbell examined ten- to eleven-year-olds, fourteen-year-olds, eighteen-year-olds, and twenty-one-year-olds, and found statistically significant differences between the youngest group and the three older groups on most competence scales. ${ }^{368}$ They did not examine twelve or thirteen-year-olds. Hein and her colleagues have examined the capacities of minors within this earlier adolescent and pre-adolescent group. ${ }^{369}$ Their work suggests that even minors as young as twelve and thirteen years of age can demonstrate adult-like competence according to legal standards. ${ }^{370}$

A Canadian panel of experts was charged with making recommendations regarding the availability of medical aid in dying to mature minors. In summarizing the body of empirical work on adolescents' competence to consent, the panel concluded: "Together, these data point to the idea that cognitive foundations for mature decisions are generally in place by early adolescence ( 12 to 15 years of age). Therefore, age should not preclude a minor from providing informed consent to the same healthcare decisions that adults are presumed capable of making." 371

Several observations regarding the findings discussed here are relevant. First, although researchers applying the studies discussed in Part III.B.2 suggest that age fifteen is the point at which minors have developed adult-like cognitive skills that facilitate the logical reasoning and understanding tasks relevant to competence, ${ }^{372}$ some who have assessed capacity according to criterion-relevant competence measures with samples including preadolescents have identified age twelve as the point at which minors do not differ significantly from adults. ${ }^{373}$ The findings from these two sets of studies are not necessarily inconsistent. It is possible that the skills required to be competent according to legal standards may not require acquisition of fully developed adult skills. Rather, those minors whose logical reasoning and cognitive analytic abilities approach adult-like levels - that is, those who are ages twelve, thirteen, and fourteen - may have attained sufficient levels of capacity to meet legal standards of treatment

${ }^{367}$ See, e.g., Weithorn \& Campbell, supra note 364, at 1596.

${ }^{368} I d$. at $1591,1595$.

${ }^{369}$ Hein et al., Children's Competence to Consent, supra note 364, at 10; Hein et al., Accuracy, supra note 364, at 1148; Hein et al., Feasibility, supra note 364, at 973; Hein et al., Informed Consent, supra note 364 , at 6-7.

${ }^{370}$ Hein et al., Children's Competence to Consent, supra note 364, at 12; Hein et al., Accuracy, supra note 364, at 1151-52; Hein et al., Feasibility, supra note 364, at 975-76; Hein et al., Informed Consent, supra note 364, at 6.

${ }^{371}$ EXPert PANEl Working GrP. ON MAID for MATURe MinOrs, COUNCIL OF CANAdian ACADS., supra note 363, at 74 .

${ }^{372} I d$.

${ }^{373} I d$. 
decisionmaking competence, despite the continued development of those abilities likely to occur in the subsequent few years.

Second, and importantly, the developmental neuroscience research reveals that socioemotional factors - that is, psychosocial maturity-can impair adolescent decisionmaking. ${ }^{374}$ Thus, in any health care context in which minors' participation in decisionmaking is sought, factors that deleteriously affect minors' abilities to exercise their logical reasoning and analytic processes should be identified, and minimized. For example, minors will be best able to make use of their cognitive capacities if they are provided with complete information, and are given time to process, analyze, and discuss the information in consultation with neutral adults such as health care professionals.

Third, not all health care decisions are the same. Two sets of factors, in particular, distinguish some decisions from others. On one hand, the complexity of the disclosed information may vary as might the difficulty of deciding among options. It is possible that some health care choices require more sophisticated cognitive decisionmaking skills than do others. This, in turn, could lead to findings of developmental differences depending on the complexity of the information and difficulty of deciding among options. This could lead to developmental differences among minors during the transitional ages of twelve to fifteen years, varying with the cognitive demands of the health care decision. On the other hand, and independent of the cognitive tasks required, health care decisions differ as well in terms of the constitutional and policy issues discussed earlier in this Article. Use of different standards of competence, and different thresholds for determining when competence is achieved, may be appropriate depending upon the nature and consequences of particular health care decisions and the constellation of interests involved.

Based on the relevant research on children's capacities, and in light of the nature and policy context of decisions regarding the recommended childhood vaccinations, we conclude that there is ample evidence that minors ages fourteen and older can be presumed to be competent to make decisions to receive vaccinations independent of parental consent. We believe that the policy goals underlying this proposal can be more efficiently achieved if states adopt a statutory age of consent of fourteen years, rather than requiring minors age fourteen and older to demonstrate capacity on a case by case basis. The more efficient option is justified in this context, where the intervention is a highly effective low risk-high benefit intervention, the risks to the child's and public's health of creating barriers to access are great, and empirical research on minors' capacities supports a policy granting decisionmaking authority to children age fourteen and older. We temper this recommendation, however, with the important caveat that,

${ }^{374}$ Id. at 81 . 
if a state makes vaccinations available to minors without parental consent, the administering health care professionals must ensure that the informed consent interaction is a thoughtful and deliberative one that facilitates the minors' best use of their cognitive capacities. This is most likely to be achieved if the administrating professional takes the time necessary to fully inform, discuss, and address questions about the immunizations.

In addition, in light of the policy goals just discussed, the low risk/high benefit profile of the vaccinations, and research findings by Hein and colleagues, ${ }^{375}$ it is reasonable to presume that minors ages twelve or thirteen are also competent to choose vaccinations for themselves. Indeed, we encourage legislatures to allow twelve- and thirteen-year-olds to provide independent consent for vaccinations if a physician finds them to be competent. Furthermore, courts employing a "mature minor" standard that does not incorporate rigid age-based criteria could, in particular circumstances, determine that any particular minor in the preadolescent age group is mature enough to decide.

4. Risk-Related or Sliding-Scale Considerations in Determining the Appropriate Threshold of Treatment Decisionmaking Competence

Health care decisions occur within particular contexts, and there may be policy reasons for setting higher or lower standards as the threshold delineating competence from incompetence. ${ }^{376}$ Some scholars emphasize the importance of examining the consequences - and particularly the risk-benefit ratio of a treatment decision - when setting the threshold for competence. $^{377}$ In elaborating upon this "sliding scale" model, Thomas Grisso and Paul Appelbaum point out that "[a]s a general rule, a lower threshold for competence is set when a patient is accepting a treatment option" with a high benefit/low risk profile. ${ }^{378}$ By contrast, "a somewhat higher threshold for competence may be required for patients who are refusing" high benefit/low risk treatments. ${ }^{379}$

In some respects, standards for decisionmaking in each health care context are an expression of the government's reconciliation of the tensions among competing goals and values inherent in the decisions. ${ }^{380}$ We may

${ }^{375}$ See supra notes $28-71$ and 364-71 and accompanying text.

${ }^{376}$ See generally GRISSO \& APPELBAUM, ASSESSING COMPETENCE, supra note 332; Dan W. Brock, Decisionmaking Competence and Risk, 5 BIOETHICs 105, 105 (1991); Ian Wilks, The Debate Over RiskRelated Standards of Competence, 11 Bioethics 413, 426 (1997); Weithorn, Aid in Dying Statutes, supra note 339 , at $687-91$.

377 GRISSO \& APPELBAUM, AsSESSING COMPETENCE, supra note 332, at 24-26; SCOTT Y. KiM, EVAluATION OF CAPACITY TO CONSENT TO TREATMENT AND RESEARCH 34-35 (2010).

${ }^{378}$ GRISSO \& APPELBAUM, ASSESSING COMPETENCE, supra note 332, at 25.

${ }^{379} \mathrm{Id}$.

${ }^{380}$ Alternatively, we can conceptualize these balances as reflecting reconciliation of competing bioethical principles of beneficence or paternalism versus decisional autonomy. See, e.g., Brock, supra note 376 , at 105 . With respect to decisionmaking for or by children, three sets of interests typically 
therefore apply lower standards of competence when the state, acting in its parens patriae or police power role, seeks to facilitate patients' access to a low risk/high benefit treatment. We can see this principle at work when we envision the prospect of refusing to give a twelve-year-old antibiotics for treatment of a sexually transmitted disease, knowing the minor may not return to the clinic with a parent if refused independent access. In this case, the strength of the parens patriae interests (ameliorating suffering and preventing serious illness, disability, or death), the police power interests (avoiding further transmission of the infection to future sexual partners of the minor and identifying past partners for treatment and counseling on preventive measures), in combination with the minor's voluntary request for services and the low risk/high benefit treatment profile could reasonably lead policymakers to apply a less demanding standard of competence. The decision of where to set the bar or threshold in determining competence is not a scientific one. It is a social policy judgment and reflects the delicate balance between competing interests. The competence threshold will and should depend on the consequences of the choices involved. For example, when a minor is choosing whether to consent to a low risk/high benefit intervention endorsed by medical consensus and government mandate, there is no reason to require the minor to demonstrate a higher level of capacity or broader array of skills than are required of adults in similar contexts. In the case of ACIP-recommended vaccinations, strong parens patriae and police power interests converge with the minors' own interests in maintaining health and exercising autonomy. By contrast, different standards and decision rules might operate if a minor wished to refuse a lifesaving treatment with a relatively low risk and high benefit profile. In that case, the minor's rejection of treatment is in conflict with the state's interest in promoting the minor's health, justifying a somewhat more persuasive demonstration of maturity. ${ }^{381}$

compete: those of the state, parents, and child. See supra Section II.B. Jennifer Rosato emphasizes the context-dependence of the decisionmaking guidelines involving children, noting that " $[t]$ he facts in each case need to be carefully considered to determine" the particular balance of potentially competing bioethical principles. Rosato, supra note 132, at 795.

381 The operation of the current constellation of policies governing minors' treatment decisionmaking in the United Kingdom provides an example. Sensible policy making may distinguish between authorizing minors to make independent decisions regarding consent to recommended treatments and authorizing them to make independent decisions regarding refusal of recommended treatments where such refusal would subject them to a substantial risk of death or serious bodily harm. See, e.g., Stephen Gilmore \& Jonathan Herring, "No" Is the Hardest Word: Consent and Children's Autonomy, 23 CHILD \& FAM. L. Q. 3, 3 (2011). For a discussion of some of the situational factors that might lead to greater scrutiny of minors' health care preferences, see Diekema, supra note 217, at 214.

We note, however, that acceptance of treatment does not necessarily argue for lower, narrower standards and rejection for higher, broader standards. A decision to refuse treatment may not trigger a broader and more searching maturity inquiry where a patient's prognosis with treatment is poor and the costs of continuing treatment outweigh the benefits. Indeed, whether sole reliance on the preferences of a capable minor in such situations is appropriate may depend, in part, on the minor's prognosis and the 
In general, therefore, when a minor's interests (in promoting and protecting his or her health and in exercising decisional autonomy) converge with the state's interests in promoting the minor's health and protecting the public's health, a lower threshold for determining capacity might be set to enable a minor to access a low risk/high benefit intervention that is medically necessary to protect against an infectious disease. Furthermore, depending on the particular decisionmaking context, the threshold dividing competence from incompetence, and the choice of standards of competence, might vary.

\section{Protecting the Confidentiality of Minors' Independent Contacts with Health Care Professionals Regarding Vaccinations}

We have analogized the need for adolescent access to vaccinations independent of parental consent to access to "sensitive" health care services, such as contraception, abortion, diagnosis and treatment for STDs, mental health and substance abuse, and sexual assault. ${ }^{382}$ Various health care provider associations recommend that when states extend to minors the legal right to consent to sensitive treatments independent of parents, the medical information must be maintained in confidence if the adolescents choose not to authorize disclosure. ${ }^{383}$ Most such associations also recommend advising

risk/benefit profile of the proposed intervention. A minor's refusal of life-saving intervention in certain contexts may require special decision rules. See, e.g., Comm. on Bioethics, Informed Consent in Decision-Making in Pediatric Practice, 138 Pediatrics 1, 4 (2016).

${ }^{382}$ See supra Section III.B.2.iii.

383 See, e.g., Am. Med. Ass'n, Code of Ethics Opinion 5.055 - Confidential Care for Minors, 16 VIRTUAL MENTOR 901, 901-02 (2014), https://journalofethics.ama-assn.org/sites/journalofethics.amaassn.org/files/2018-05/coet1-1411.pdf ("For minors who are mature enough to be unaccompanied by their parents for their examination, confidentiality of information disclosed during an exam, interview, or in counseling should be maintained. Such information may be disclosed to parents when the patient consents to disclosure."); Ass'n of Women's Health, Obstetric \& Neonatal Nurses, Confidentiality in Adolescent Health Care: Position Statement, 46 J. Obstetrical GynecologiCal \& NeOnatal NURSES 889,889 (2017) ("Nurses are responsible to provide safe, high quality, confidential health care to adolescents."); Pamela J. Burke et al., Soc'y for Adolescent Health \& Med., Sexual and Reproductive Health Care: A Position Paper of the Society for Adolescent Health and Medicine, 54 J. ADOLESCENT HEALTH 491, 492 (2014) ("Be aware of and promote the availability of confidential [sexual and reproductive health] services to ensure that adolescents, especially those at greatest risk, do not forego needed care."); Comm. on Adolescence, Am. Acad. of Pediatrics, The Adolescent's Right to Confidential Care when Considering Abortion, 139 PEDIATRICS 1, 1 (2017) ("[The AAP] reaffirms its position that the rights of adolescents to confidential care when considering abortion should be protected."); Am. Acad. of Family Physicians, Adolescent Health Care, Confidentiality, AAFP.OrG, https://www.aafp.org/about/policies/all/adolescent-confidentiality.html (last visited Oct. 7, 2019) ("Physicians should deliver confidential health services in situations involving sexuality (including sexually transmitted infections, contraception, and pregnancy), substance use/abuse, and mental health to consenting adolescents."). See also NAT'L ACADS. OF ScIS., EnG'G, \& Med., The Promise of Adolescence: ReAlizing OpPoRTUNity For All Youth 231-35 (Richard J. Bonnie \& Emily P. Backes eds., 2019) (addressing the importance of ensuring confidentiality and privacy for adolescents in the context of screening and services for "sensitive" health matters). 
adolescents to involve their parents in their health care decisions whenever possible, while recognizing that, without protections for confidentiality, many minors will forego seeking services. ${ }^{384}$

Research findings and clinical experiences reveal that minors' concerns about parental access to health care information can be a major deterrent to adolescents seeking, and therefore receiving, needed care for sensitive health matters (such as those related to sexual activity and reproduction, sexually transmitted diseases, mental health or substance use, or sexual assault). ${ }^{385}$ For example, one comprehensive national study reported that

U.S. adolescents who forgo care due in whole or in part to confidentiality concern are a particularly high-risk population in need of health care services. Among boys, prevalence of mental health difficulties was significantly higher among those who cited confidentiality concern as a reason for forgone care, as compared with those who did not cite confidentiality concern. Among girls, those citing confidentiality concern had a significantly higher prevalence of risk characteristics related to mental health, sexual/reproductive health, and substance use. . . [A]dolescents who reported elevated depressive symptom levels, suicidal ideation, suicide attempt, sexual activity, birth control nonuse at last sex, STI history, alcohol use, and/or unsatisfactory parental communication were significantly more likely than adolescents who did not report these factors to cite confidentiality concern as a reason for not seeking needed care in the past year. ${ }^{386}$

\footnotetext{
${ }^{384}$ For examples of such recommendations, see Am. Med. Ass'n, Code of Ethics Opinion 5.055 Confidential Care for Minors, supra note 383, at 901; Pamela J. Burke et al., Soc'y for Adolescent Health \& Med., supra note 383, at 492; Comm. on Adolescence, Am. Acad. of Pediatrics, supra note 383, at 1; Am. Acad. of Family Physicians, Adolescent Health Care, Confidentiality, supra note 383, at 1.

${ }^{385}$ See, e.g., Jocelyn A. Lehrer et al., Foregone Health Care Among U.S. Adolescents: Associations Between Risk Characteristics and Confidentiality Concern, 40 J. AdOLESCENT HEALTH 218, 222 (2007) (examining "risk characteristics of adolescents for whom confidentiality concerns" deterred use of health care services); Jami S. Leichliter et al., Confidentiality Issues and Use of Sexually Transmitted Disease Services Among Sexually Experienced Persons Aged 15-25 Years-United States, 2013-2015, 66 MORBIDITY \& MORTALITY WKLY. REP. 237, 239 (2017) (reporting a relationship between minors' reluctance to seek reproductive and sexual health care and concerns of disclosure to parents). See also supra Section III.B.

${ }^{386}$ Lehrer et al., supra note 385 , at 222 . Other studies support the observation that a substantial proportion of adolescents who forego needed medical care do so out of concerns about confidentiality. See, e.g., Tina L. Cheng et al., Confidentiality in Health Care: A Survey of Knowledge, Perceptions and Attitudes Among High School Students, 269 JAMA 1404, 1407 (1993); Carol A. Ford et al., Foregone Health Care Among Adolescents, 282 JAMA 2227, 2232 (1999); Jonathan D. Klein et al., Access to Medical Care for Adolescents: Results from the 1997 Commonwealth Fund Survey of the Health of Adolescent Girls, 25 J. AdOLESCENT HEALTH 120, 125 (1999).
} 
We expect that in the absence of confidentiality for services related to vaccinations, minors will likewise be deterred from seeking care independent of parental consent. Parents who have refused vaccinations for their minor children have already registered their strong opposition to the minor's receipt of vaccinations by rejecting medical recommendations and refusing to comply with legal requirements. Minors in the age groups that we recommend be eligible to receive vaccinations without parental consent will be aware of their parents' viewpoints on these matters.

Legal protections for confidentiality of minors seeking medical services independent of parental consent vary across states and with types of health care service. ${ }^{387}$ At the federal level, parents typically have full access to their child's medical records under the Health Insurance Portability and Accountability Act (HIPAA)'s rules, because they act as their child's personal representatives. ${ }^{388}$ HIPAA's provisions indicate, however, that when a minor exercises a personal legal right to obtain the relevant treatment - that is, if the minor has a right to consent directly-the minor retains independent control over her records. ${ }^{389}$ Yet, HIPAA's policy may not be the last word on this matter. HIPAA typically defers to state regulations concerning parental authority and minor children's health care information. ${ }^{390}$ Depending on the particular state policies, such deference may "allow or prohibit disclosure of confidential information [regarding adolescents' health care] to parents or guardians." 391 Therefore, state legislators have substantial control over the level of privacy protection given to health care information flowing from adolescents' contacts with health care professionals. Legislators can pair statutory authorization for minors to

387 See ABIGAil ENGLiSH ET AL., GUTTMACHER INST., CONFIDENTIALITY FOR INDIVIDUALS INSURED AS DEPENDENTS: A REVIEW OF STATE LAWS AND POLICIES 5-6 (2012), https://www.guttmacher.org/sites/default/files/report_pdf/confidentiality-review.pdf; JOY PRITTS ET AL., Health Policy Inst. \& O’Neill Inst. for Nat'L \& Glob. HeAlth LaW, Privacy and SECURITy SOLUTIONS FOR INTEROPERABLE HEALTH INFORMATION EXCHANGE: REPORT ON STATE MEDICAL RECORD ACCESS LAWS 3-12-3-18 apps. A-8a-A-9d (2009), https:/www.healthit.gov/sites/default/ files/290-05-0015-state-law-access-report-1.pdf; Amy L. McGuire \& Courtenay R. Bruce, Keeping Children's Secrets: Confidentiality in the Physician-Patient Relationship, 8 Hous. J. HEALTH L. \& POL'Y 315, 320-28 (2008); Amy B. Middleman \& Kelly A. Olson, Confidentiality in Adolescent Health Care, UPTODATE (Aug. 5, 2019), https://www.uptodate.com/contents/confidentiality-in-adolescent-healthcare.

388 Uses and Disclosures of Protected Health Information: General Rules, 45 C.F.R. § 164.502(g)(3)(i) (2018); see also ENGLISH ET AL., supra note 387, at 5-6; PRITTS ET AL., supra note 387, at $3-11-3-12$.

389 Uses and Disclosures of Protected Health Information: General Rules, 45 C.F.R. $\S$ 164.502(g)(3)(i) (2018); see also ENGLISH ET AL., supra note 387, at 5-6 (discussing HIPAA confidentiality standards); PRITTS ET AL., supra note 387, at 3-11.

${ }^{390}$ PRITTS ET AL., supra note 387, at 3-11-3-12.

${ }^{391}$ HIPAA, Final Rule, 65 Fed. Reg. 82,462 (Dec. 28, 2000); Standards for Privacy of Identifiable Health Information, 67 Fed. Reg 53,182, 53,199-53,203 (Aug. 14, 2002); Melissa Weddle \& Patricia K. Kokotailo, Confidentiality and Consent in Adolescent Substance Abuse: An Update, 7 VIRTUAL MENTOR 239, 240 (2005) (citations omitted). 
consent to vaccines with protection of the confidentiality of the health care information related to those services. We recommend such confidentiality provisions as an essential component of such legislation.

Even when state laws prohibit disclosure of adolescent health care information to parents by health care professionals, however, this protection would not automatically prevent the parent from receiving an Explanation of Benefits (EOB) from the insurance company if the minor uses the parent's health insurance plan to pay for the vaccinations. ${ }^{392}$ Many states require EOBs to be provided to subscribers to prevent health fraud. ${ }^{393}$ This requirement has already created privacy concerns for young adults (ages eighteen and older) who are covered on their parents' health plans until age twenty-six. ${ }^{394}$ Similar disclosure problems have arisen in the context of treatment for sexually transmitted diseases. ${ }^{395}$ Regulation of obligations to provide EOBs for a specific treatment typically occurs at the state level, together with insurance company or plan policies. ${ }^{396}$ Therefore, it will be necessary for state legislators to include a provision that protects minors against inadvertent disclosure of their vaccinations through insurance communications to parents.

\section{STATES LEGISLATION AUTHORIZING MINORS' CONSENT TO VACCINATION: A PROPOSAL}

As discussed in Parts II and III, there are strong grounds to authorize minors to consent to vaccines, independent of their parents. We agree with Silverman and colleagues on this issue that doing so is consistent with a range of policy objectives and ethical principles in health care delivery and is justified by the literature on adolescents' decisionmaking. ${ }^{397}$ This Section develops a legislative proposal.

We strongly recommend enacting the proposed changes via statute. Legislative enactment constitutes a more effective mechanism for introducing policy reform than does case-by-case judicial determination. First, statutes can contain clear, specific language and criteria for the purpose

${ }^{392}$ ENGLISH ET AL., supra note 387, at 9-13.

${ }^{393} \mathrm{Id}$. at 5.

${ }^{394}$ Id.; Valerie K. Blake \& Jessica A. Haught, Health Care at a Price: The Impact on Young Adults' Medical Privacy and Autonomy of Being Covered on Their Parents' Health Insurance Until Age Twenty-Six, 51 FAM. L.Q. 303, 304 (2017).

${ }^{395}$ HARRIET B. FoX \& STEPHANIE J. LimB, InCENTER STRATEgIES: THE NAT’L All. TO ADVANCE Adolescent Health, State Policies Affecting the Assurance of Confidential Care for ADOLESCENTS 1-2 (2008), http://ww2.nasbhc.org/RoadMap/CareManagement/Special\%20Topics/ State\%20Policies\%20and\%20Confidential\%20Care\%20for\%20Adolescents\%20NAAAH.pdf; Ctrs. for Disease Control \& Prevention, Sexually Transmitted Diseases Treatment Guidelines, 2010, 17 MORBIDITY \& MORTALITY WKLY. REP. 1, 10 (2010), https://www.cdc.gov/mmwr/pdf/rr/rr5912.pdf.

${ }^{396}$ FOX \& LIMB, supra note 395, at 3-4 (noting that state policies govern EOB requirements even for Medicaid).

${ }^{397}$ Silverman et al., supra note 11, at 104. 
of regulating the relevant subject matter. Drafters can anticipate a broad range of fact patterns that may fall within the purview of the statute. By contrast, judicial decisions vary substantially in the degree to which they merely resolve the dispute before the court or can delineate rules that will govern prospectively. Second, legislatures are generally viewed as more competent in developing policies that respond to social needs and changes for the purpose of bringing about prospective law reform. ${ }^{398}$ While courts may and do respond to such changes when necessary to resolve a dispute or adjudicate a constitutional challenge, various doctrines (such as stare decisis) and judicial philosophies (such as judicial restraint in deciding cases as narrowly as possible) limit the potential breadth of a holding's applicability. ${ }^{399}$ Third, legislatures can engage in research that takes into account scientific information, epidemiological data, and other sources that will inform their lawmaking. Courts may also consider such sources, but may be limited by the rules of evidence as well as the proclivities of individual judges to consider extra-legal knowledge and expertise. ${ }^{400}$ Fourth, legislation can avoid conflicts with existing statutes by referencing the relationship between the new provisions and existing law. If such potential conflicts are not raised by the parties in litigation, it is possible the conflicts will not be addressed by a judicial decision. ${ }^{401}$ Finally, as we note below, in the context of authorizing minors to have independent access to vaccinations, there are uniquely legislative functions - such as allocation of funds - that are required for effective implementation of the policies. In addition, only the legislature can ensure that companion provisions essential to the efficacy of the policy reform, such as confidentiality protections, are included in the reform package. Because it is possible that not all states will pass such statutes, however, Part V suggests a limited judicial solution in the absence of a legislative response.

398 See, e.g., Stuart A. Scheingold, The Politics of Rights: Lawyers, Public Policy, AND Political Change, at xxiii-xxiv (2d ed. 2004); Jed Barnes, In Defense of Asbestos Tort Litigation: Rethinking Legal Process Analysis in a World of Uncertainty, Second Bests, and Shared Policy-Making Responsibility, 34 LAW \& SOC. INQUIRY 5, 6-7, 15-16 (2009) (contrasting judicial and legislative functions).

${ }^{399}$ Barnes, supra note 398, at 8, 10; Doriane Lambelet Coleman \& Philip M. Rosoff, The Legal Authority of Mature Minors to Consent to General Medical Treatment, 131 PEDIATRICS 786, 788 (2013). Note that courts sometimes do step in successfully when legislatures do not act. In general, however, policy reforms are more frequently and appropriately effectuated by legislatures. Barnes, supra note 398, at $6-7,15-16$.

${ }^{400}$ Barnes, supra note 398 , at 8, 10 .

${ }^{401}$ For example, below we observe that the complex interplay of federal and state confidentiality protections, as well as the regulations regarding insurance company dissemination of Explanations of Benefits to subscribers, may conflict with, and thereby undercut, state policies allowing minors to consent independently to vaccinations. See supra notes 387-97 and accompanying text. Therefore, it will be necessary for the legislature to take proactive steps to reconcile the potential conflicts when creating an exception to the doctrine of parental consent as applied to recommended vaccinations. 
Our central proposal, however, recommends statutory reform, creating a treatment-specific exception to the doctrine of sole parental consent in the context of childhood vaccinations. The exception would authorize certain groups of minors to consent independently to ACIP-recommended vaccinations. Such an exception is consistent with the law creating other limited exceptions to the policy of parental control over health care decisions for their minor children. Over the last several decades, the laws governing such exceptions have become increasingly well-established and uncontroversial. Furthermore, our proposed exception is also consistent with the recent legislation and court decisions that promote compliance with mandatory vaccination policies. Indeed, we are not aware of successful legal challenges to mandatory immunization policies. In particular, multiple courts have already held that school-entry immunization requirements are necessary to address a compelling state interest in protecting the public's health by preventing the spread of disease. ${ }^{402}$

The research on children's development and health care decisionmaking reveals that minors age fourteen and older should be presumed capable of consenting to the recommended childhood vaccines. ${ }^{403}$ Age fourteen is also consistent with, for example, the age of consent identified in many states' statutory or case law mature minor exceptions. ${ }^{404}$ Even younger minors are permitted to provide consent for vaccines related to sexually transmitted infections in, for example, California. ${ }^{405}$ Given the relevant policy considerations, high benefit/low risk profile, and medical consensus regarding advisability of recommended vaccines, together with research on children's decisionmaking capacities, we contend that minors ages twelve and thirteen are also competent to consent to recommended childhood vaccinations. In the case of minors ages twelve and thirteen, however, we recommend that states require that physicians evaluate minors' capacities to make the decision before authorizing such consent as an additional precaution to ensure that all minor consents are competent. ${ }^{406}$

Our proposal is, to some extent, asymmetrical. It authorizes minors to consent to vaccines independent of their parents but does not authorize

${ }^{402}$ Workman v. Mingo Cty. Bd. of Educ., 419 F. App’x 348, 355-56 (4th Cir. 2011); Whitlow v. California, 203 F. Supp. 3d 1079, 1091 (S.D. Cal. 2016); Brown v. Smith, 24 Cal. App. 5th 1135, 1146 (Cal. Ct. App. 2018).

${ }^{403}$ See supra Section III.B.3.

${ }^{404}$ See, e.g., ALA. CODE $§ 22-8-4$ (Westlaw through Act 2019-540) (authorizing any minor age fourteen or older to give effective consent for medical care); Cardwell v. Bechtol, 724 S.W.2d 739, 745 (Tenn. 1987)

${ }^{405}$ See, e.g., CAL. FAM. CODE § 6926(b) (West, Westlaw through 2019 Regular Sess. ch. 524) (“A minor who is 12 years of age and older may consent to medical care related to prevention of a sexually transmitted disease"); Table of State Laws Relevant to Minors' Consent to Vaccinations Independent of Parents, https://docs.google.com/spreadsheets/d/1uUDrkdYqzzSG9icTTSHEIWQbgtm0uFVGtBZ7rT DU8sQ/edit?usp=sharing (last visited Oct. 16, 2019).

${ }^{406}$ See supra notes $367-72$ and accompanying text. 
minors to refuse vaccines where their parents provide consent. Decisional structures in other health care contexts involving minors might lead to a different allocation of decisional authority between parents and children. In each context, such allocations follow from analysis of the constitutional, policy, and practical considerations; the risk-benefit profile of the specific intervention; the medical consensus concerning recommendations for the specific health care intervention; and the capacities of minors to make health care decisions. ${ }^{407}$ In the context of ACIP-recommended vaccines, which are low risk/high benefit health care interventions endorsed by a consensus of medical experts and state legislatures to promote the welfare of the vaccinated minor and the public's health, both parent and competent child should possess the legal right to consent, even over the objection of the other.

We consider also the process for obtaining the minor's informed consent. The federal National Childhood Vaccine Injury Act requires the disclosure of specified information included in the Vaccine Information Statement (VIS) to the vaccine recipient or his or her legal representative prior to vaccinating. ${ }^{408}$ Under our proposal, minors authorized to consent to vaccination would become the legally designated recipients of the VIS. We recommend additional guarantees for the informed consent process when minors are the persons consenting so as to ensure that the recipient's acquiescence reflects a meaningful consent process. ${ }^{409}$ The vaccine administrator should review the VIS after the minor has received and read it, and offer to answer questions for the minor, emphasizing sections describing the disease that the vaccination was developed to prevent and its risks, who should not be vaccinated, the vaccine's risks, and what the minor should do if experiencing a problem following the vaccination. Furthermore, we recommend that the minor be asked to initial each of these sections and

${ }^{407}$ See supra Part II.B.2. For further discussion of "asymmetries" in minors' involvement in health care decisions, see, for example, Neal C. Manson, Transitional Paternalism: How Shared Normative Powers Give Rise to the Asymmetry of Adolescent Consent and Refusal, 29 BIOETHICs 66, 67 (2015).

${ }^{408} 42$ U.S.C. $\$ 300 a a-26(d)$ (2) (Westlaw through Pub. L. No. 116-108) (“[N]ot later than 6 months after the date such materials are published in the Federal Register, each health care provider who administers a vaccine set forth in the Vaccine Injury Table shall provide to the legal representatives of any child or to any other individual to whom such provider intends to administer such vaccine a copy of the information materials developed pursuant to subsection (a), supplemented with visual presentations or oral explanations, in appropriate cases. Such materials shall be provided prior to the administration of such vaccine.").

${ }^{409}$ There are good grounds to think that an adult-informed consent process should also involve an oral explanation, and certainly an opportunity to ask questions. See Dorit Rubinstein Reiss \& Nili Karako-Eyal, Informed Consent to Vaccination: Theoretical, Legal, and Empirical Insights, 45 AM. J.L. \& MED. 357, 400 (2019) ("[W]hile the first circulate determines that the information may be provided to parents orally, in writing, or through pamphlets, the second circulate clarifies that an information form does not replace oral explanation (suggesting that an oral discussion is necessary even if written materials are provided)."). Legislatures can-and we think should-put in place additional procedural requirements to ensure that minors are adequately informed and have the opportunity to discuss any questions or concerns. 
indicate via signature that the information was explained to him or her, and that he or she has had the opportunity to ask questions to clarify understanding. This procedure sets up the conditions for cold cognition, facilitating minors' best use of their cognitive capacities in light of the decisionmaking task before them. ${ }^{410}$

The Vaccine Information Statement is accessible, clear, and provides the information needed for a vaccine decision. ${ }^{411}$ It satisfies the general legal requirements for disclosure of information under informed consent law. As pointed out by Silverman and colleagues, the current VIS is written at a tenth grade reading level. ${ }^{412}$ This language may therefore need to be modified for minors who have not yet reached tenth grade. Until revised materials are developed, the oral explanation of the vaccine administrator and clarifications that follow any questions raised by a minor will be crucial complements to the document, together with the minor's signed acknowledgement of receipt of the explanation. ${ }^{413}$

As we emphasize above, ${ }^{414}$ the interplay of HIPAA and state confidentiality provisions may lead to inadequate protection for the privacy of health care information flowing from minors' legally authorized independent contacts with providers regarding vaccination consultation and receipt of immunizations. Therefore, it is incumbent upon state legislators to incorporate confidentiality protections into statutes that authorize to consent for vaccinations.

An additional risk to the confidentiality of medical information is present when vaccinations are paid for through minors' parents' private insurance policies and minors receive vaccines without parental consent. ${ }^{415}$ Insurance company dissemination of EOBs to parents informs them of the minor's receipt of the vaccinations paid for through their insurance plan. The challenges attending minors' use of parental insurance to pay for vaccinations underscore the potential barrier that financing of vaccines may pose to minors' independent access to vaccinations. In general, in the United States, vaccines are paid for either under private or public insurance programs such as Medicaid or under the Vaccines for Children Program. ${ }^{416}$ This latter program provides ACIP-recommended vaccines as a federal

\footnotetext{
${ }^{410}$ See supra Section III.B.2.

${ }^{411}$ Reiss \& Karako-Eyal, supra note 409 , at 418.

${ }^{412}$ Silverman et al., supra note 11, at 105-06.

${ }^{413} \mathrm{Id}$.

${ }^{414}$ See supra Section III.C.

${ }^{415}$ Under the Affordable Care Act, insurance plans that are not grandfathered must cover vaccines recommended by the Advisory Committee on Immunization Practices. 42 U.S.C. § 300gg-13(a)(2) (Westlaw through Pub. L. No. 116-108).

${ }^{416}$ See How to Pay, U.S. DeP'T HEALth \& HuM. SERVICES, https://www.vaccines.gov/getting/pay (last visited Oct. 9, 2019) (providing information about the different ways to pay for vaccines).
} 
benefit to uninsured or underinsured children. ${ }^{417}$ In order to eliminate barriers related to cost or disclosure of medical information from insurance companies, we recommend that states: (1) allow minors to receive vaccines free of charge in health departments; (2) adopt provisions prohibiting insurers from sending EOBs listing vaccines that were administered to minors without parental consent; and (3) allow pharmacies to sell vaccines to eligible minors who choose to pay independently, consistent with pharmacies' authority to sell such vaccinations to adults in that state.

Research reveals that health care professionals frequently have incomplete information about the often-complex confidentiality rules that apply to health care interventions with adolescents. ${ }^{418}$ Therefore, when implementing a statute authorizing minors' consent to vaccinations, state officials must ensure that vaccine administrators (that is, physicians, nurses, state health officials, pharmacists, and others) are familiar with the applicable confidentiality protections for the minors. Because liability for any harm from vaccines - a possible, although highly unlikely scenario - is already covered by a no-fault federal program, the proposal need not address the potential liability of the provider. ${ }^{419}$

Finally, the success of our proposal in facilitating competent minors' voluntary access to recommended vaccinations requires that such minors be made aware of this option and how to exercise it. Ethan Lindenberger, in an interview with the authors, highlighted the need to provide teens with the information about the availability and processes for obtaining vaccines. ${ }^{420}$ We recommend that state departments of health incorporate information about such options and procedures for minors' consent into the websites they maintain to educate the public about school immunization requirements. Such information can also be incorporated into the health education modules in the public school curricula. States can also require public school districts to post such information on the school district websites.

\section{Proposed Statute: Authority of Older Minors to Consent to Vaccination}

1. Purpose: this statute's purpose is to provide requesting minors with the authority to consent to vaccines recommended for their age group, or for younger children if they did not receive the vaccinations at those earlier ages,

417 Vaccines for Children Program, CENTERs FOR DisEASE CONTROL \& Prevention, https://www.cdc.gov/vaccines/programs/vfc/index.html (last visited July 29, 2019).

${ }^{418}$ Margaret Riley et al., Physician Knowledge and Attitudes Around Confidential Care for Minor Patients, 28 J. Pediatric \& AdOLESCENT GyneCOlogy 234, 239 (2015).

${ }^{419}$ H. Cody Meissner, Narayan Nair \& Stanley A. Plotkin, The National Vaccine Injury Compensation Program: Striking a Balance Between Individual Rights and Community Benefit, 321 JAMA 343, 343 (2019).

${ }^{420}$ Skype Interview with Ethan Lindenberger (June 16, 2019) (recording with authors). 
if their parents are unwilling or unable to consent to vaccination.

2. Eligible minors, as defined in this section, may consent to receiving vaccines recommended for their age and medical status, or recommended for younger children (if the minors did not receive the vaccines at the recommended ages), by the federal Advisory Committee on Immunization Practices (ACIP), without need for parental consent. Eligible minors are:

a. Minors age fourteen years and older.

b. Minors ages twelve and thirteen, upon determination in writing by a physician that the minor is capable of consenting to vaccination. The authorizing physician can administer the vaccination, direct another health care professional to administer the vaccination, or write a prescription authorizing other professionals legally qualified to administer vaccines in this state, such as pharmacists or nurses, to administer the vaccinations.

c. Emancipated minors.

3. "Capacity to consent" under Section $2 \mathrm{~b}$ requires that the individual understand the nature and consequences of the proposed vaccination (that is, the risks and benefits of the vaccination to be administered) and is capable of making and communicating an informed decision concerning the administration of the vaccine.

4. A consenting minor, acting as her or his own legal representative under this act, will receive the Vaccine Information Statement (VIS) required under 42 U.S.C. $\S$ 300aa-26. The vaccine administrator will explain the sections addressing the disease that the vaccine is intended to prevent and its risks, who should not be vaccinated, the vaccine's risks and what to do if there is an adverse reaction, and will offer to answer and will answer any questions regarding this information. The minor will initial those sections and sign a form indicating that the minor was provided and understands the explanation of the vaccine's risks and benefits.

5. Any branch of the state Department of Health will provide vaccines free of charge to minors seeking to vaccinate under this act.

6. The confidentiality of minors who request vaccinations shall be protected. Laws addressing medical freedom shall 
be interpreted to permit non-disclosure of medical information related to the request and provision of vaccinations to minors who seek immunization without parental consent. To the extent permissible by federal law, Explanations of Benefits related to administration of vaccinations to minors eligible under Section 2 of this statute, will not be sent to parents. Insurance programs may implement alternatives to prevent fraud in these areas.

7. Pharmacies and other locations providing vaccines, including school clinics, may administer vaccines to eligible minors without parental consent under the conditions and requirements specified in this act.

8. The state's health department will include information about minors' right to consent on the state's public education website that describes the state's school immunization requirements, on pages providing general information about vaccines, and on other pages likely to appear in internet searches for the information by a minor.

\section{JUdiCIAL CREATION OF A TREATMENT-SPECIFIC MATURE MinOR RULE AUTHORIZING CAPABLE MINORS TO CONSENT TO VACCINES IN THE ABSENCE OF PERTINENT STATE LEGISLATION}

We recognize that, despite the advantages of implementing our recommendations through legislative reform (that is, development of a coordinated framework that establishes a right to vaccinations for eligible minors, addresses practical barriers to vaccinating, and provides clear guidance to providers and agencies), there may be obstacles to passage of such a statute. Vaccine-resistant parents, in spite of their strong appeal to the language of choice and right when it comes to fighting school mandates, ${ }^{421}$ may vehemently oppose legislation allowing minor children to get vaccinated over parental opposition. ${ }^{422}$

${ }^{421}$ Barbara Loe Fisher, Forcing Vaccination on Every Child Undermines Civil Liberties, LEAPS MAG. (Mar. 28, 2019), https://leapsmag.com/forcing-vaccination-on-every-child-undermines-civilliberties (characterizing state vaccination mandates as "elimination of civil liberties, including freedom of speech and the right to dissent guaranteed under the First Amendment of the U.S. Constitution").

${ }^{422}$ This is an experience-based observation, not a theoretical prediction. In several states that introduced such legislation, anti-vaccine activists resisted strongly. For a relatively measured anti-vaccine response, see Kate Raines, New York Bill Would Strip Parental Consent for Vaccinating Children, VACCINE REACTION (Mar. 28, 2019), https://thevaccinereaction.org/2019/03/new-york-billwould-strip-parental-consent-for-vaccinating-children; and, for a more typical response, see AMA Says Mature 12-Year-Olds Can Consent to Vaccination Without Parents Taking Away the Last Barrier Protecting Innocent Children from Big Pharma, Child. HeAlth DeF. (June 18, 2019), https://childrenshealthdefense.org/news/ama-says-mature-12-year-olds-can-consent-to-vaccinationwithout-parents-taking-away-the-last-barrier-protecting-innocent-children-from-big-pharma. 
In the absence of such legislation or an existing mature minor doctrine, we recommend that courts adopt a narrow mature minor doctrine allowing capable minors to become vaccinated without parental consent. In support of this doctrine we cite the strong parens patriae interests and high benefit/low risk profile for recommended childhood vaccination (that is, the expert consensus that, absent medical contraindications, vaccination is the safer course of action for the minor, providing protection from the dangerous effects of the vaccine-preventable diseases); the important police power interests (that is, the benefits of decreasing the threat to the public from disease outbreaks); and the evidence that adolescents and many preadolescents are capable of making decisions regarding vaccinations. ${ }^{423}$ Furthermore, we recognize minors' right to protect their own health and well-being, particularly when their personal choices are aligned with the state's interests. In light of the misinformation that appears to be guiding many vaccine-resistant and vaccine-hesitant parents, it is both reasonable and good public policy to allow minors to correct an objectively ill-founded parental decision that endangers their health. ${ }^{424}$

States with a mature minor doctrine typically do not set a specific age for the doctrine, though Tennessee's courts apply the rule of sevens used in other areas of tort law to suggest that minors over the age of fourteen are presumed capable to consent, while minors age seven to thirteen are rationale.

${ }^{423}$ See supra Section II.B for a full discussion of the mature minor doctrine and its underlying

${ }^{424}$ Several states, such as Illinois, Kansas, Tennessee, and Washington have broader mature minor doctrines than the specific, vaccine-related one proposed here. See In re E.G., 549 N.E.2d 322 (Ill. 1989) (holding that a "mature" seventeen-and-a-half-year-old minor may refuse a lifesaving blood transfusion); Younts v. St. Francis Hosp. \& Sch. of Nursing, Inc., 469 P.2d 330 (Kan. 1970) (holding that a "mature" minor may consent to a beneficial surgical procedure); Cardwell v. Bechtol, 724 S.W.2d 739 (Tenn. 1987) (holding that a mature minor has the capacity to consent to medical treatment); Smith v. Seibly, 431 P.2d 719 (Wash. 1967) (holding that a mature minor may give valid consent to a surgical procedure). Coleman and Rosoff suggest that a state's silence as to the existence of a mature minor doctrine should not be taken as leaving open a door, but as a reaffirmation of the traditional principles of parental consent. Coleman \& Rosoff, supra note 15, at 791. Similarly, the existence of other exceptions to the rule of parental consent can, as mentioned, be read as implying lack of other exceptions under the omitted case canon which states that "[n]othing is to be added to what the text states or reasonably implies (casus omissus pro omisso habendus est). That is, a matter not covered is to be treated as not covered." ANTONIN SCALIA \& BRyAn A. GARNER, REAding LAW: The INTERPRETATION OF LEGAL TEXTS 93 (2012).

However, we do not agree that this principle necessarily applies here. Statutory exceptions to the general rule of parental consent are enacted when the legislature seeks to create such an exception, and it is not limited in its authority by the existence of the general doctrine. When a legislature drafts a statute focusing specifically on, for example, whether minors can consent to treatment for STDs, the more specific legislation provides the governing authority. The omitted case canon can be legitimately applied if the statute creating the exception specifies the inclusion of treatment, for example, for HIV and Chlamydia, but is silent on, for example, treatment for HPV, and there is a question as to whether the general doctrine or limited exception applies to treatment for HPV, since the application of the exception will be limited to that which it explicitly covers. The legislature may further create other treatment-specific parental consent exceptions incorporating mature minor principles. 
presumed not to have the ability to consent. ${ }^{425}$ Both presumptions are rebuttable if contrary persuasive evidence is presented. ${ }^{426}$ Other states focus on capacity, not age, in determining maturity. ${ }^{427} \mathrm{We}$ recommend that, consistent with our proposal above, reviewing courts hold that minors over fourteen can consent to vaccines recommended for them. Furthermore, we recommend that the court should examine the capacity to consent of younger minors and allow minors who are mature-applying a treatment decisionmaking capacity standard of maturity - to consent to recommended vaccines.

Minors found capable under the doctrine should be permitted to consent to both childhood vaccines and adolescent vaccines recommended by the Advisory Committee of Immunization Practices. When the minor is completely or partially unvaccinated, "catch-up schedules" created by the CDC can guide vaccine administrators and minors as to the appropriate timing and spacing of vaccines going forward. Judicial decisions should also, to the extent possible under state privacy laws, protect the confidentiality of the minor's decision to vaccinate.

Judicial doctrines do not, however, solve the problems of funding discussed in Part IV. Furthermore, it is uncertain whether courts can protect confidentiality in the face of state medical privacy laws or insurance company policies that permit parents access to information regarding their minor child's request or receipt of vaccinations. In some states, health departments provide free or low-cost vaccines, and minors can find options by consulting with the health department (or using online services) ${ }^{428}$ Use of parental insurance without a statute addressing explanations of benefits would likely alert parents to the minor's receipt of vaccinations. State medical privacy laws may also create parental rights to access minors' medical records. Judges may have limited authority to alter the application of such policies, although there may be room for interpretations that will protect a minor's confidentiality.

\section{CONCLUSION}

Modern parental refusals of childhood vaccinations differ dramatically from many other circumstances in which parents reject the recommendations of health care professionals when exercising their legal discretion in health care decisionmaking for their children. There is an epidemic of

${ }^{425}$ Cardwell v. Bechtol, 724 S.W.2d 739, 746-49 (Tenn. 1987).

${ }^{426}$ Coleman \& Rosoff, supra note 15 , at 789 .

${ }^{427}$ Cardwell, 724 S.W.2d at 748 (stating that application of the mature minor rule is a question of fact for the jury as to "the minor's ability to appreciate the risks and consequences" of the treatment, as well as several other factors).

${ }^{428}$ Where to Go, U.S. DEP'T HEALTH \& HUM. SERVICES, https://www.vaccines.gov/getting/where (last visited Oct. 16, 2019). 
misinformation regarding the safety and efficacy of vaccines influencing the judgment of vaccine-resistant and vaccine-hesitant parents. This epidemic has proven remarkably impervious to correction through education and persuasion. This phenomenon, in turn, places children who are intentionally unvaccinated at medical risk while also threatening the health of many in the public who are too young or medically unable to be vaccinated. For these reasons, policymakers must consider alternatives in the vaccination context to the default of sole parental decisionmaking for their minor children's health care. The evidence indicates that teenagers are capable of understanding the risks and benefits of vaccinations and of making competent informed decisions to be vaccinated. Children of vaccine-refusing parents should be authorized to receive accurate medical information about the recommended childhood vaccinations upon request. If such minors reach a decision regarding vaccination that is in conflict with that of their parents, they should be legally authorized to provide independent consent to the administration of the vaccinations.

In an interview with Ethan Lindenberger addressing his decision to vaccinate, Ethan explained his moment of understanding of the minimal degree of risk presented by vaccines:

When people say there's a risk to vaccines, and that nothing is without risk, that makes the world sound so dangerous and scary. When that vocabulary is so misleading ... it's the same thing as saying there's always a risk of going to sleep, there's always a risk in like driving a car. Honestly, it's a million times more scary driving a car than getting vaccines. And that's the thing I didn't realize ... yes, there is a "potential" that is below a one in a million chance, you're more likely to die [from] a coconut. So, I never heard that. And understanding that was so important, because when I realized that and looked at the math I realized: "well, duh, this is fine." And I went in and everybody was really kind . . . . ${ }^{429}$

Further, understanding the social consequences sealed the decision for him:

The biggest part was learning that vaccinating wasn't just for yourself-it was for other people in your community. So learning that part was a thing that really pushed me, where I said "wow, being unvaccinated could end up causing a disease to transmit from me to someone else-and that person could die." 430

${ }^{429}$ Skype Interview with Ethan Lindenberger (June 16, 2019) (recording with authors).
${ }^{430} \mathrm{Id}$. 
Ethan revealed himself to be a socially conscious, responsible, and caring teen - as many parents wish their teens to be. He realized that he was putting others at risk by not being vaccinated and wished to correct that problem.

When, prior to the age of eighteen, Ethan decided he wanted to receive immunizations, he faced legal barriers. He thus began the process to become vaccinated upon reaching adulthood. There too he faced challenges. In the final analysis, he received his vaccines at his local health department rather than through his health care provider (although with the knowledge and support of his provider). ${ }^{431}$ Adolescents who have decided to make the responsible choice for themselves and the public to become vaccinated now face legal barriers. Our state governments must eliminate these barriers. We recommend that states adopt our proposal in light of the converging interests of the state and the minor. The courageous decisions of teens to receive vaccinations despite their parents' opposing viewpoints must be supported rather than burdened or barred. The default of parental consent more appropriately applies to contexts in which there is not a conflict between the interests of parents and their children and that do not contribute to a growing threat to the public's health. 